\title{
ENVIRONMENTAL STATEMENT HTGR FUEL REFABRICATION PILOT PLANT
}

Oak Ridge National Laboratory Oak Ridge, Tennessee

AUGUST 1974
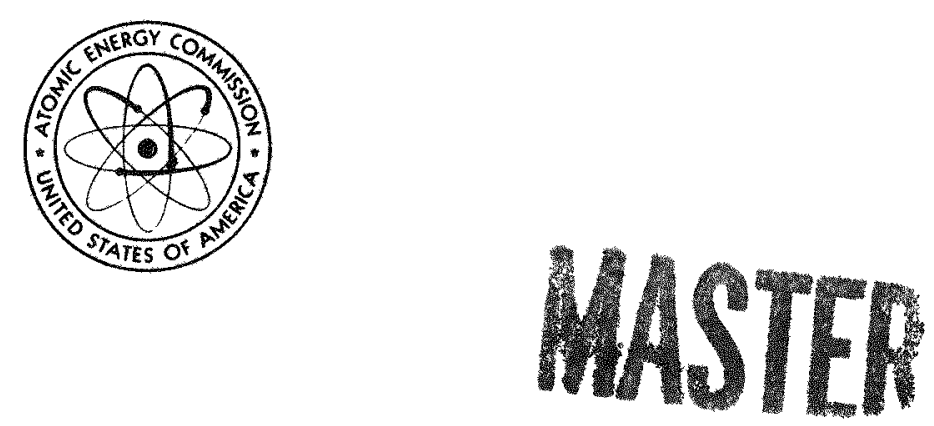

UNITED STATES ATOMIC ENERGY COMMISSION

RESPONSIBLE OFFICIAL:

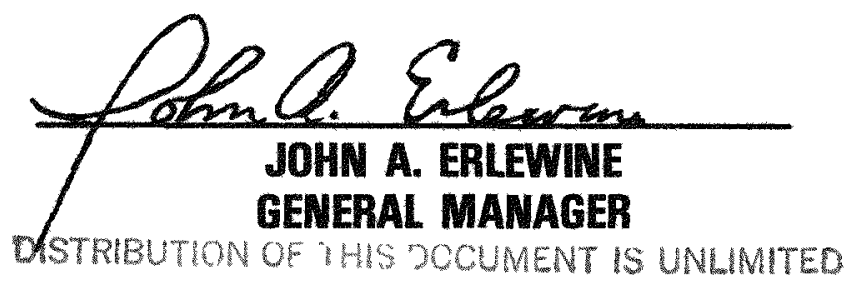




\section{LEGAL NOTICE}

This report was prepared as an account of work sponsored by the United States Government. Neither the United States nor the United States Atomic Energy Commission, nor any of their employees, nor any of their contractors, subcontractors, or their employees, makes any warranty, express or implied, or assumes any legal liability or responsibility for the accuracy, completeness or usefulness of any information, apparatus, product or process disclosed, or represents that its use would not infringe privately owned rights. 


\section{DISCLAIMER}

This report was prepared as an account of work sponsored by an agency of the United States Government. Neither the United States Government nor any agency Thereof, nor any of their employees, makes any warranty, express or implied, or assumes any legal liability or responsibility for the accuracy, completeness, or usefulness of any information, apparatus, product, or process disclosed, or represents that its use would not infringe privately owned rights. Reference herein to any specific commercial product, process, or service by trade name, trademark, manufacturer, or otherwise does not necessarily constitute or imply its endorsement, recommendation, or favoring by the United States Government or any agency thereof. The views and opinions of authors expressed herein do not necessarily state or reflect those of the United States Government or any agency thereof. 


\section{DISCLAIMER}

Portions of this document may be illegible in electronic image products. Images are produced from the best available original document. 
FINAL

ENVI RON ENTA L STATEUENT

HTGR PUEL REFABRCATION PILOT PLANT

\title{
OAK RIDGE NATIONAL IABORATORY
}

\section{August 1974}

\begin{abstract}
This report was prepared as an account of work sponsored by the United States Government. Neither the United States nor the United States Atomic Energy Commission, nor any of their employees, nor any of their contractors, subcontractors, or their employees, their contractors, subcontractors, or their employees,
makes any warranty, express or implied, or assumes any makes any warranty, express or implied, or assumes any pleteness or usefulness of any information, apparatus, product or process disclosed, or represents that its use would not infringe privately owned rights.
\end{abstract}


○

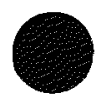


CONTENTS

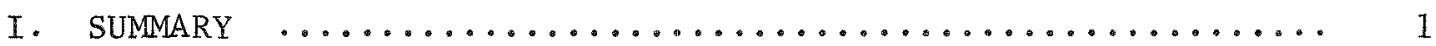

II. BACKGROUND AND DESCRIPTION OF PROPOSED PROJECT $\ldots \ldots \ldots \ldots . .3$

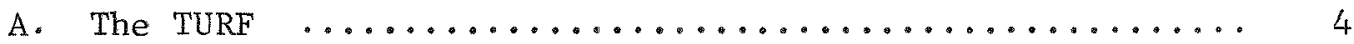

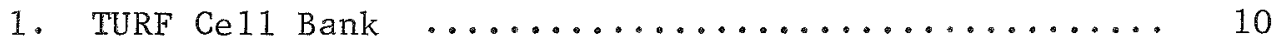

2. Design Basis for Cell. Shielding ............. 14

B. HTGR Fuel Refabrication Pilot Plant ............. 14

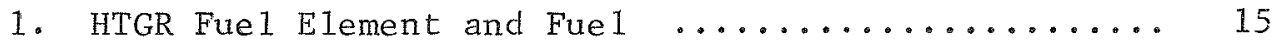

2. Uranium Feed Material ................... 18

3. Uranium Feed Material Transfer ............... 18

4. Fue1 Refabrication Processing ............... 19

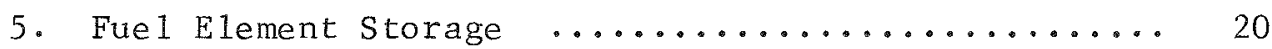

6. Fuel Element Transfer and Shipment ........... 21

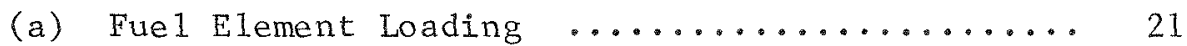

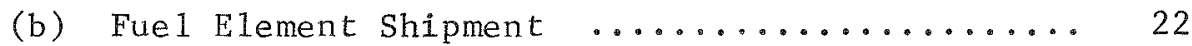

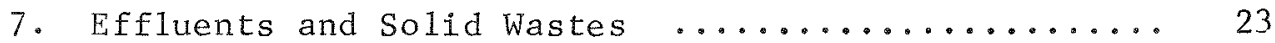

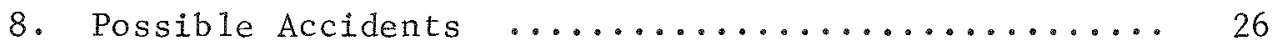

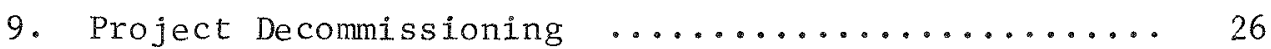

(a) Decommissioning of Remote Processing Cel1s ... 27

(b) Decommissioning of Cell $\mathrm{E} \ldots \ldots \ldots . \ldots . \ldots 28$

C. Anticipated Benefits ...................... 28

1. Need for Project ......................... 29

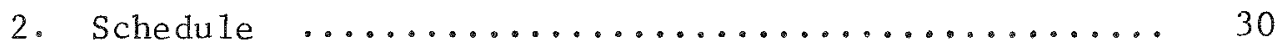

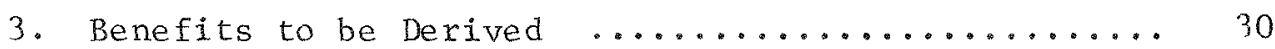

(a) Benefits From Fuel Recycle $\ldots \ldots \ldots \ldots \ldots \ldots . \ldots . \ldots 32$

(b) Benefits From HTGR Fue1 Refabrication
Pilot Plant $\ldots \ldots \ldots \ldots \ldots \ldots . \ldots \ldots . \ldots \ldots$

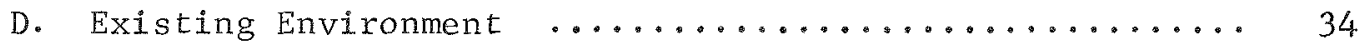

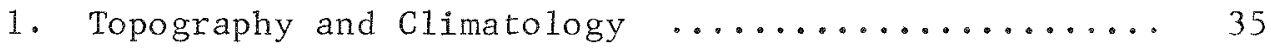

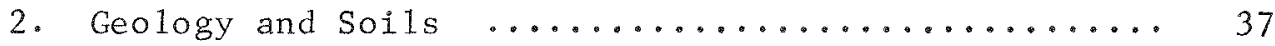

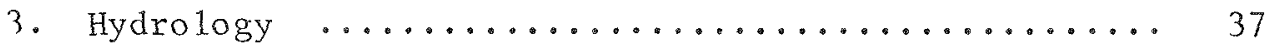

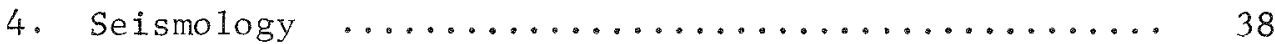

5. Ecology of Site and Environs $\ldots \ldots \ldots \ldots \ldots \ldots \ldots$ 


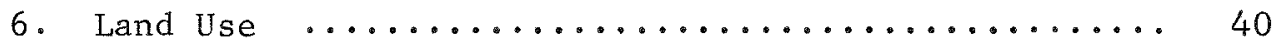

E. Monitoring of Existing Environment $\ldots \ldots \ldots \ldots \ldots \ldots \ldots . . \ldots 1$

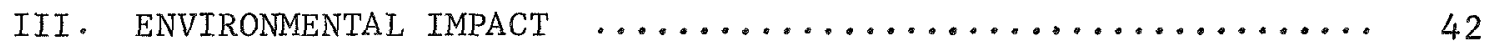

A. Probable Environmental Effects $\ldots \ldots \ldots \ldots \ldots \ldots \ldots \ldots . . \ldots 2$

1. Discharges to the Atmosphere .............. 43

(a) Radioactive Emissions ................ 43

(b) Estimated Dose From Long-Lived Radionuclides

After Project Decommissioning ........... 46

(c) Chemical Emmissions $\ldots \ldots \ldots \ldots \ldots \ldots \ldots \ldots$

2. Discharges of Liquids .................. 49

(a) Radioactive Emissions ................. 49

(b) Chemical Emissions $\ldots \ldots \ldots \ldots \ldots \ldots \ldots \ldots \ldots \ldots \ldots \ldots \ldots \ldots$

3. Solid Waste Disposal .................... 51

4. Land Use and Construction Impact ............ 51

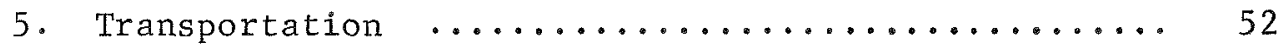

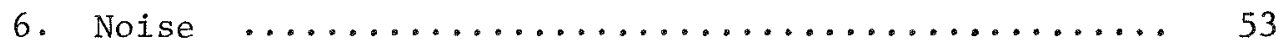

7. Project Decommissioning ................... 54

B. Accidents .............................. 54

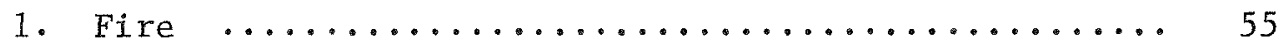

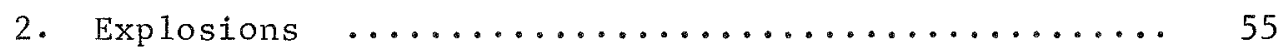

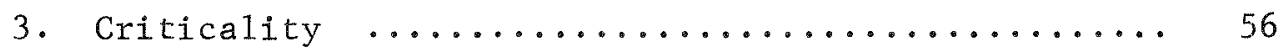

4. Natura1 Disturbances $\ldots \ldots \ldots \ldots \ldots \ldots \ldots \ldots \ldots \ldots$

(a) Earthquakes $\ldots \ldots \ldots \ldots \ldots \ldots \ldots \ldots \ldots \ldots . \ldots \ldots$

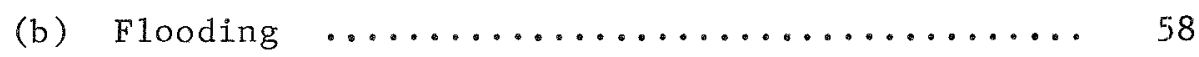

(c) High Winds $\ldots \ldots \ldots \ldots \ldots \ldots \ldots \ldots \ldots \ldots \ldots \ldots \ldots$

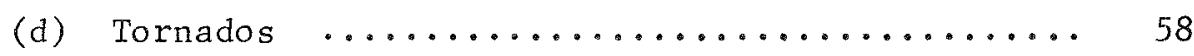

5. Handling Accidents ..................... 59

6. Response to Accidenta1 Release of Radioactivity ... 60

IV. UNAVOIDABLE ADVERSE ENVIRONMENTAL EFFECTS ............ 60

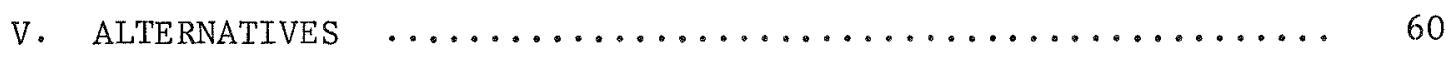

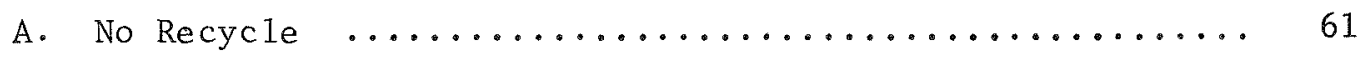

B. Delay in Recycle $\ldots \ldots \ldots \ldots \ldots \ldots \ldots \ldots \ldots \ldots \ldots \ldots \ldots . \ldots \ldots$

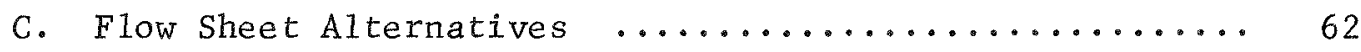

1. Microsphere Preparation .................. 62

2. Microsphere Coating ................... 63 


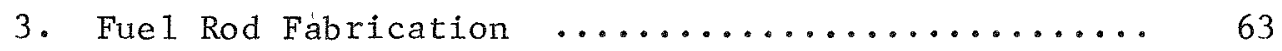

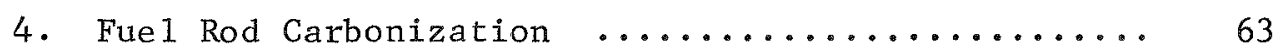

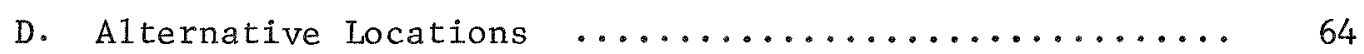

VI. RELATIONSHIP BETWEEN SHORT-TERM USE AND

LONG-TERM PRODUCTIVITY ...................... 64

VII. STATE, LOCAL, OR REGIONAL CONFLICTS .............. 65

VIII. IRREVERSIBLE AND IRRETRIEVABLE COMMITMENTS OF RESOURCES . 65

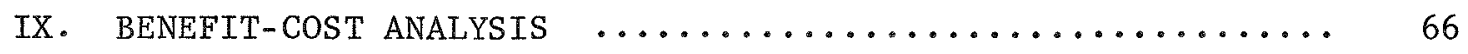

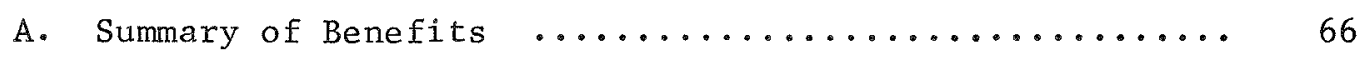

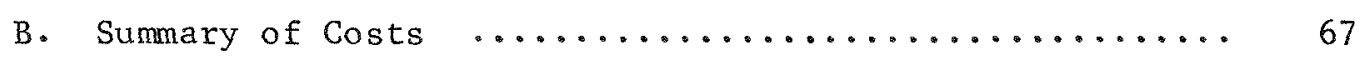

C. Benefit-Cost Evaluation of Alternatives $\ldots \ldots \ldots \ldots \ldots .67$

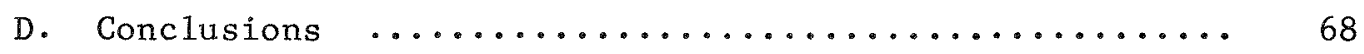

X. SAFEGUARD CONSIDERATIONS $\ldots \ldots \ldots \ldots \ldots \ldots \ldots \ldots \ldots \ldots \ldots$

A. Nature and Quantities of Special Nuclear Material ... $\quad .68$

B. Physica1 Protection .............................. 69

C. Material Control and Accountability ........... 70

D. Safeguard Provisions for Materials in Transit ...... 70

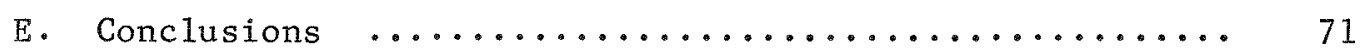

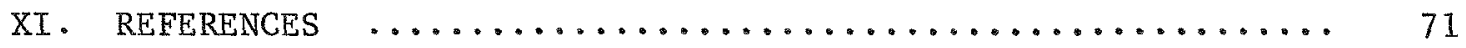

Appendix A: SOURCE TERMS FOR WASTES TO BE GENERATED BY HTGR FUEL REFABRICATION PILOT PLANT OPERATION $\ldots \ldots \ldots \ldots .77$

Appendix B: CHARACTERIZATION OF EXISTING ENVIRONMENT $\ldots \ldots \ldots \ldots . . .81$

Appendix C: ENVIRONMENTAL MONITORING OF EXISTING ENVIRONMENT $\ldots . .97$

Appendix D: ATMOSPHERIC DISPERSION OF STACK RELEASES . . . . . . . 104

Appendix E: ENGINEERING DRAWINGS $\ldots \ldots \ldots \ldots \ldots \ldots \ldots \ldots \ldots \ldots \ldots \ldots \ldots$

Appendix $\mathrm{F}$ : COMMENTS AND AEC RESPONSES ............... 116 
O

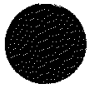


Figure

Number

1
Title

Page Number

\section{5} Laboratory

The TURF and Nearby Facilities

$$
6
$$

7

8

9

11

12

13

16

16

24

25

31

35

36

39

83

87

in the Period 1930 Through 1969

Recurrence Curves for (a) Total Southeast Region,

(b) Mississippi Valley Area, and (c) Southern Appalachian Mountain Zone

Vegetation Type Map for the Area Surrounding the TURF

Perimeter Air Monitoring (PAM) Network

Remote Air Monitoring (RAM) Network

100

Location of Milk Sampling Stations 
C.4 Location of Sampling Stations for Nonradioactive

D.1 Log Polar Isopleths of Expected Annual Average Stack

109 Dilution Factors for the Plant Site 
Tab le Number

B. 1

B. 2

D. 1
Title

Page

Number

17

33

41

44

45

47

48

50

62

Penalties Associated With Delay in Commercial Reprocessing of Spent HTGR Fue 1

Chemical Effluents From Stack Resulting From HTGR

Fuel Refabrication Pilot Plant Operation

Solid Chemical Effluents Resulting From HTGR Fuel Refabrication Pilot Plant Operation

Fue 1 Refabrication Pilot Plant Operation

Radiological Effluents From Stack Resulting From HTGR Fuel Refabrication Pilot Plant Operation

MonthIy Climatic Summary for the Oak Ridge Area Based on a 20-Year Record

Incremental Population Data for TURF Site

Frequency of Wind Speed and Wind Direction Under C-Stability Conditions at Oak Ridge National Laboratory 
Table

Number

D. 2
Frequency of Wind Speed and Wind Direction Under E-Stability Conditions at Oak Ridge National Laboratory

D.3 Annual Average Stack Dilution Factors of Effective Area Perimeter
Page

Number

107

108 


\section{SUMARI}

This environmental statement was prepared in accordance With the National Environental Policy act of 1969 in support of the United states Atomic Energy Comission's proposal for legislative authorization and appropriations for a fiscal-year 1975 project. The purpose of the proposed project is to demonstrate the technology for refabrication of uranium-233 for use in high-te perature gas-cooled reactors operating on the thorium fuel cycle. The high-temperature gas-cooled reactor (HTGR) jis of interest as an additional source of electrical power because of its relatively efficient use of fissionable material, its conservation of natural resources through the use of the thoriu fuel cycle, and its relatively low thermal discharge rate. Although the HTGR is a comercially arailable type of reactor. the United states Atomic Energy Comission (USAEC) is supporting the development of processes for reprocessing and refabricating HTGR fuel.

The capital cost of this facility was estimated in mid-1973 at $\$ 10$ million. Since that time, there has been additional design ork done. In addition. increasing esca.lation and lengthen ing construction material deliveries are being experienced. Consequently. the AEC has undertaken to review and fir up the estimated cost prior to start of construction. Hovever even a several fold increase in the cost of this facility would not greatly alter the balance of the economical benefits expected to be derived from its construction and operation to HTGR fuels technology. The magnitude of the economic benefits of HTGR fuel recycle have been estimated using an analytical model of the nuclear energy industry hich includes light ater reactors and liquid metal fast breeder reactors as well as the HTGR. BI the year 2020. savings of nuclear fuel worth approximately $\$ 2$ billion in 1974 dollars are projected to cesult from recycling the fuel in the HTGR. The proposed project includes the design. construction, and operation of an integrated pilot plant to develop and demonstrate the HTGR fuel refabrication technology. This project is coordinated ith the HTGR fuel ceprocessing pilot plant that is planned at the National Reactor Testing station (NRTS) in Idaho Palls, Idaho. These profects complement each other in the development of HTGR fuel recycle technology.

The proposed HTGR Fuel Refabrication Pilot Plant ill be installed in the existing Thoriu-n raniu Fuel cycle Development Facility (TORF) at Oak Ridge National Iaboratory (ORNL). The TURF is a hot cell facility that as built specifically for pilot plant use, and the proposed pilot plant ill occup the hot cells and some adjacent building areas ithin the TURF. The proposed pilot plant is scheduled for two years of operation, beginning in calendar year 1978, for refabrication technology de onstration purposes. Anual operating costs during its two year 1 ife are estimated at $\$ 4$ ilion. The plant ill have the capability for performance of a 11 processing 
operations beginning with the receipt of uranium nitrate solution from the National storage Facility for uranium-233 and ending with the delivery of completed fuel elements to an operating reactor or the HTGR Fuel storage Facility at the NRTS in Idaho. The throughput capacity of the plant will be approximately 25 kilograms of heavy metal (two and one-half fuel elements) per day, with a yearly capability of about 200 fuel elements over the 2-year operation period.

The existing TURF is situated on a knoll well above the flood plain in the Melton Valley area of ORNL, which is an area of infrequent tornados and low-probability earthquakes. The nearest population center with over 35,000 persons is 15 miles away. The ecological systems of the areas surrounding the proposed project site are typical of those in the Appalachian region of the united states.

The possible accidents which could occur during operation of the proposed pilot plant that were evaluated included those resulting from fire, explosions, criticality, and natural disturbances. Such accidents have a low probability of occurrence because of the design of the existing hot cell facility and pilot plant and because of existing administrative controls.

Construction operation, and decomissioning of the proposed HTGR Fuel Refabrication pilot Plant are expected to have an insignificant impact on the environment. The gaseous and liquid effluents that ill result from operation of the proposed pilot plant will be discharged to existing waste handling and treatment systems, and the radioactive and chemical enissions will be several orders of magnitude lower than the established guidelines or background levels. The solid wastes generated by operation and decommissioning of the proposed pilot plant ill be disposed of and stored by using procedures designed to protect the environment that will not require an extension of existing solid waste disposal

facilities.

Because of its small scale and short life, the proposed project ill have an insignificant effect on the long-ter productivity of the environment. The irceversible and irretrievable comitment of resources for the project will consist almost entirely of aterials for construction and thoriu in the feed aterial in amounts which are not significant. The proposed project is not known to be in conflict with local, state, or regional plans or programs. The principal benefits from the proposed project will be the generation of technological information essential to the design. construction, and operation of large-scale commercial HTGR fuel refabrication plants and the verification of process and equipment designs at a stage of development when changes vill be relatively inexpensive. It is also expected that operating data from the pilot plant will ake possible a more accurate assessment of the environmental effects of large-scale fuel refabrication programs. 
Aditional benefits of the proposed project will be the production of refabricated HTGR fuel elements for possible use in an operating HTGR.

The major alternatives to the proposed project that were considered were those of no recycling of HTGR fuel, a delay in the proposed schedule for pilot plant operation, process and equipment options and another location for the pilot plant. It was concluded that any of those alternatives would result in either an increased environmental impact over that of the proposed project or increased costs ith no reduction in envi ronmental impact.

It was concluded that the societal and environmental costs of the proposed project will be negligible and that the motary costs will be justified by the production of refabricated fuel elements for recycle demonstration in a HTGR and by the anticipated benefits of increased technology for HTGR fuel refabrication for future comercial application.

\section{BACKGROUND AND DESCRIPTION OF PROPOSED PROJECT}

The purpose of the proposed project is to deanstrate the technology for refabrication of uranium-233 for use in hiqh-temperature gas-cooled reactors operating on the thorium fuel cycle. and the projected cost of the project is $\$ 10$ million (the preliminary nature of this 1973 cost estimate was discussed in section $I$.$) The proposed project includes the$ design. construction, and operation of an integrated pilot plant to develop and demonstrate the technology necessary for fabrication of HTGR fuel elements from recycled uranium-233 fuel for comercial HTGR. This pilot plant 11 have the capability for performance of all processing operations beginning with the receipt of uraniu nitrate solution fron the National storage Pacility for oranin-233 (BIdg. 3019 at ORNL) and ending with the delivery of completed fuel elements to an operating HTG or to the HTGR Fuel storage Pacility at NRTS for storage. The throughput capacity of the plant will be approximately 25 kilograms of heavy 4 mal per day or about two and one-half completed fuel elements. On the basis of a three-shift day and a five-day veek and a processing campaign of about a 2-week duration every six weeks. the production capacity of the plant 111 be about 200 fuel elements per year over the 2-year pjlot plant operation period.

since the uraniu feed aterial will contain gama-emitting daughter products from uranium-232, it ill be necessary for the refabrication process to be performed in a remotely operated hot cell facility. The proposed HTGR Puel Refabrication Pilot plant ill be installed in the existing Thorium-Uranium Puel Cycle Development Facility. Building 7930. at ORIL. Which is located on the USA EC Dak Ridge Reservation in Tennessee. The USAEC Oak Ridge Reservation 
contains three major operating facilities: the oak Ridge National Laboratory. the Oak Ridge Gaseous Diffusion PIant. and the $1-12$ plant. In adition two smaller usAEC facilities are in the area. These are the UT-ACC Comparative Animal Research Laboratory and the oak Ridge Associated universities.

The oak Ridge National Laboratory is a large multipurpose research laboratory whose basic ission is the discovery of new knonledge, both basic and applied, in all areas related to nuclear energy. To accomplish this ission, the laboratory conducts research in all fields of modern science and technology. The Laboratory facilities consist of nuclear reactors chemical pilot plants, research laboratories, radioisotope production laboratories and support facilities.

The Thorium-Oranium Fuel cycle Development Facility is locally referred to at ORNL as the Thorium-0ranium Recycle Facility (TURF) and is so designated in the following description and accompanying illustrations. The TURF is located in the Melton valley area of oRv, as is illustrated in Fig. 1. and nearby facilities include the High-Flux Isotope Reactor (HFIR). the HFIR office and mintenance building, and the Transuraniu Processing plant (TRU), as shom in Fig. 2.

\section{A. The TURP}

The TURF, Building 7930, is a three-story structure with a partial basement that was designed in accordance with the Southern Building code for Group-G industrial occupancy. It is constructed of structural steel, celnforced concrete, and masonry. The building is of irregular shape with an overall Idth of $124 \mathrm{ft}$, an overall length of about $162 \mathrm{ft}$ and a gross floor area of $32.950 \mathrm{ftz}$ exclusive of hot cells.

The first floor of Building 7930 provides space for technical personnel offices, cell operation and hantenence. a receling area, a fuel storage room wh a deep vater-filled basin. hot and cold change cooms. a compressor roon, and an elevator room. as shown in Fig. 3 .

The second floor provides space for che ical akeup. sampling of radioactive aterials a development laboratory. a warm shop, a maintenance area, echanical and lectrical equipment rooms a cask decontamination station a checking and holding area, and orking space around cell as shown in Fig. 4.

The third floor, aigh bal. includes the cell roof area and provides facilities for cell access and entry of cell services, as shown in Fig. 5. It is equipped ith a 50-ton orerhead traveling bridge crane lith a 5-ton aulliary hoist. some of the third-floor space is used for cell and building ventilation equipent, and other portions ill be used as necessary for nockup of cell process equiphent.

partial basement pro ides space for access to cell p and for installation and intenance of equipment i a pup room adjacent to cell G. 


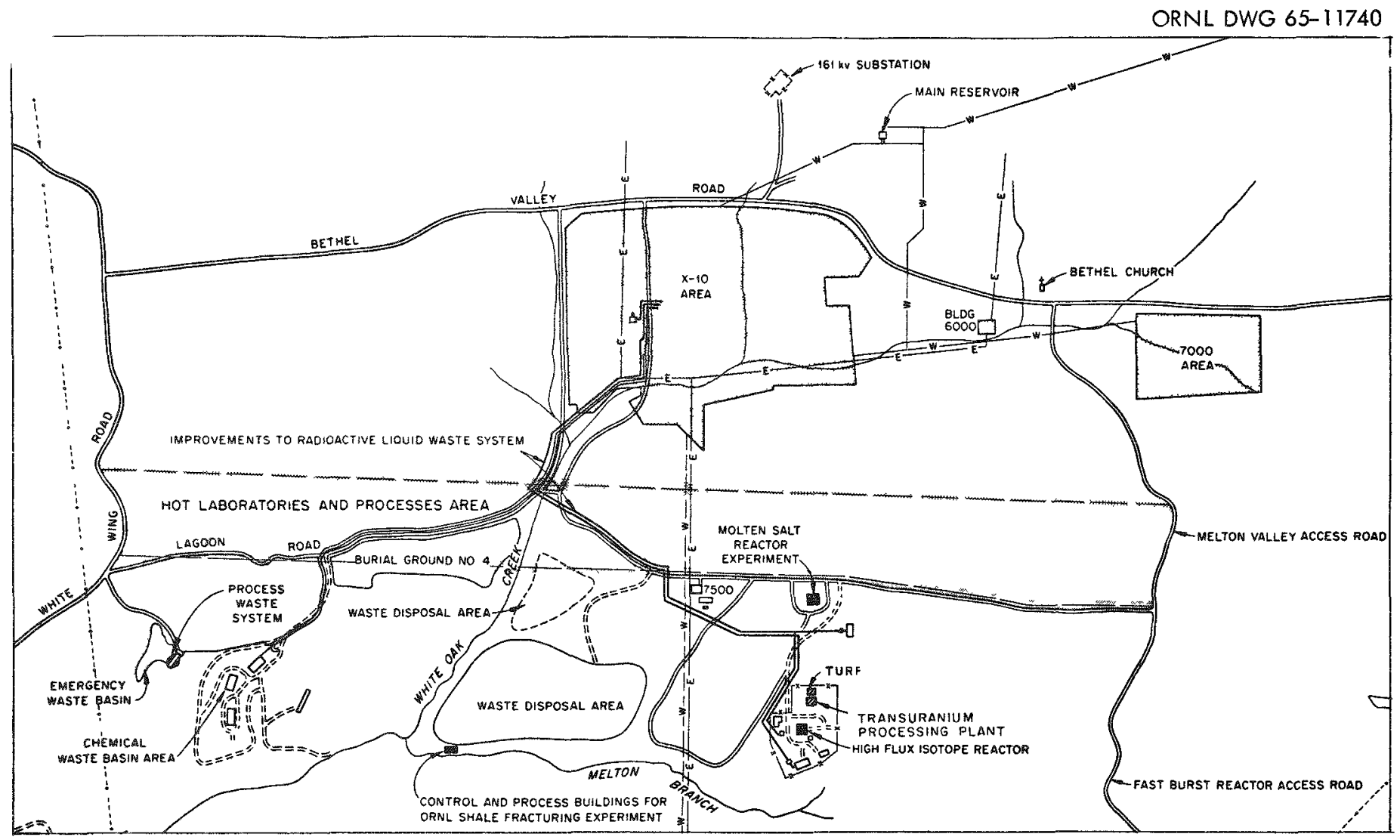

Fig. 1. Area Map of Melton Valley at Oak Ridge National Laboratory. 


\section{thes}

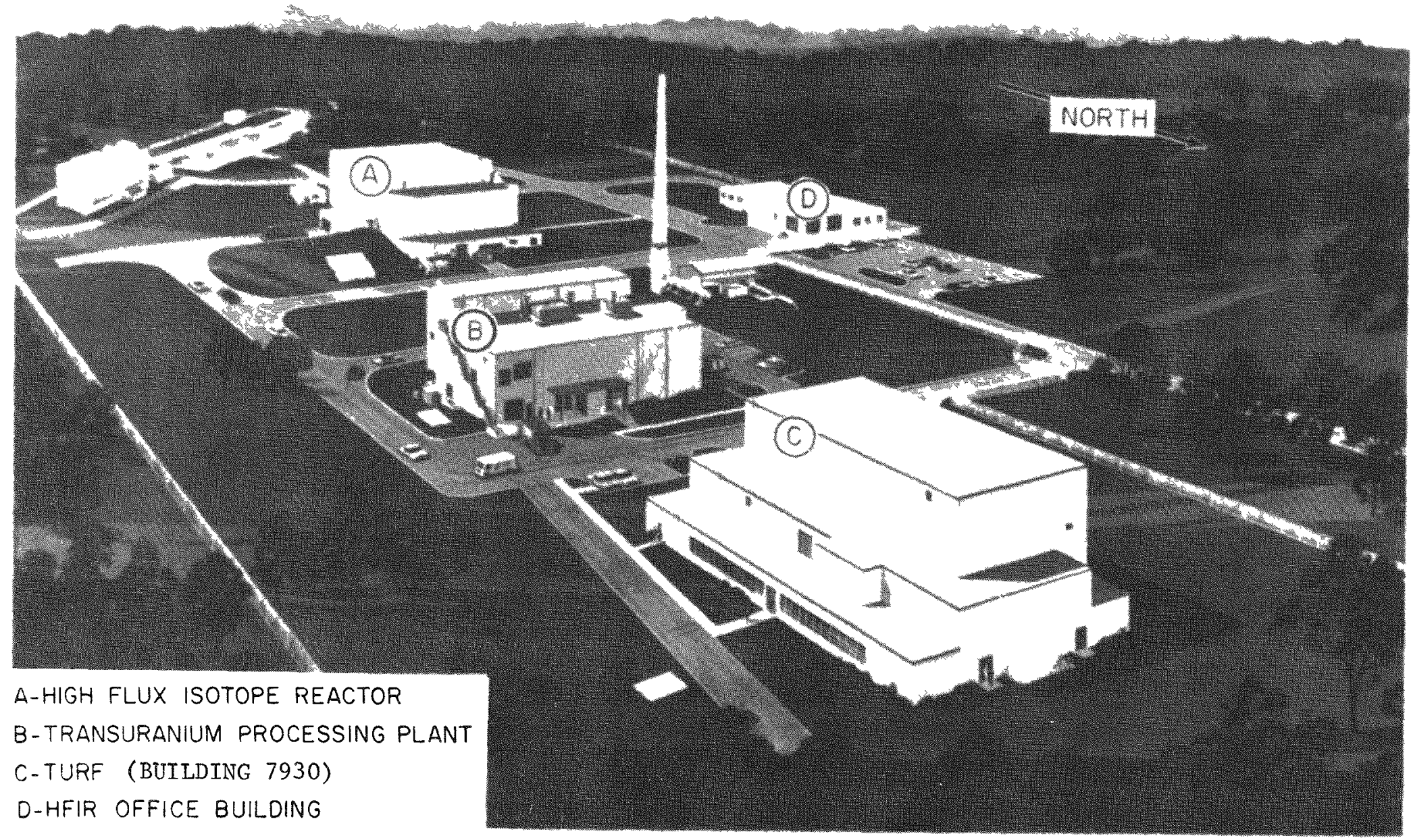

Fig. 2. The TURF and Nearby Facilities. 


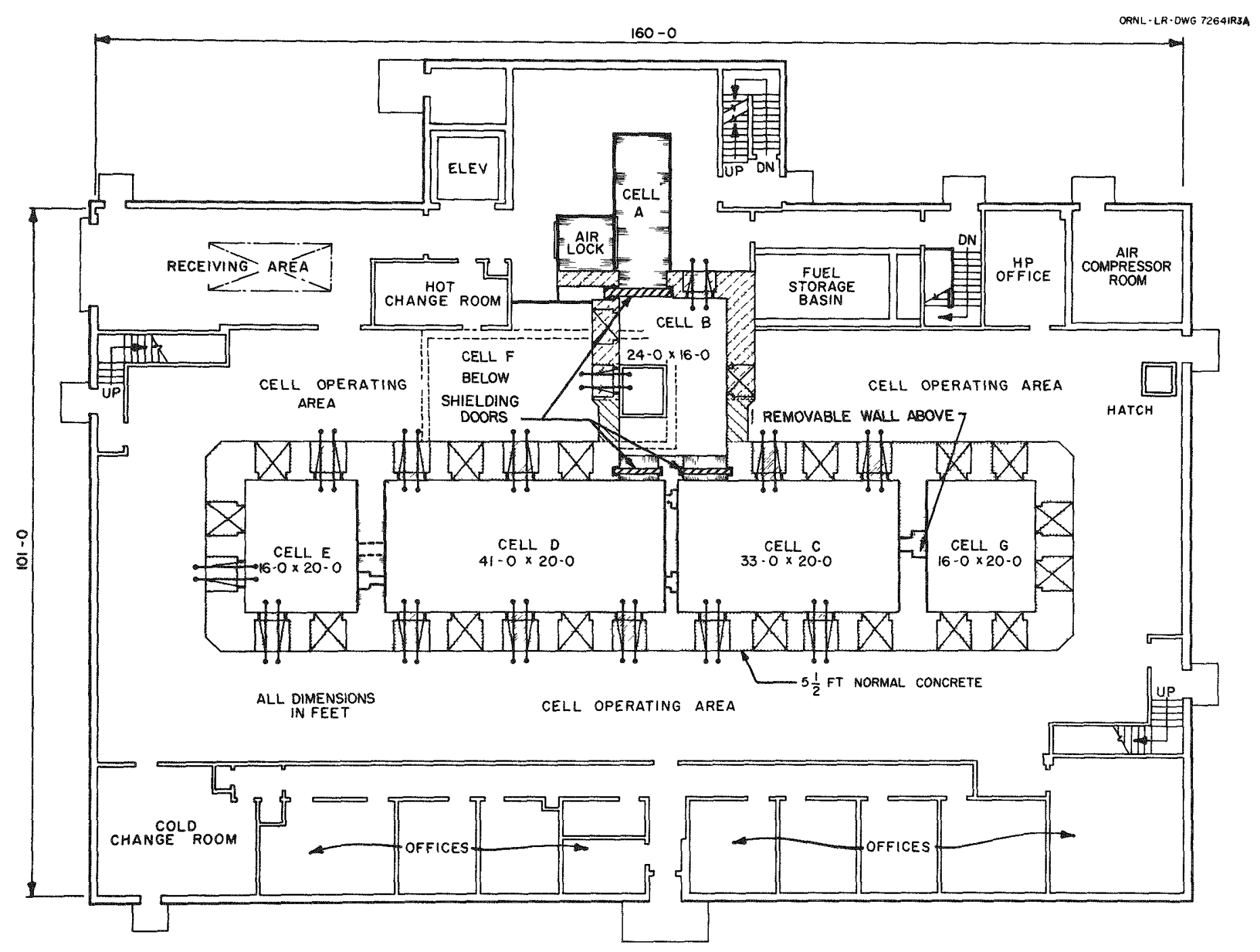

Fig. 3. First Floor Plan of Building 7930 (TURF). 
ORAL DWG. 64-3334RI

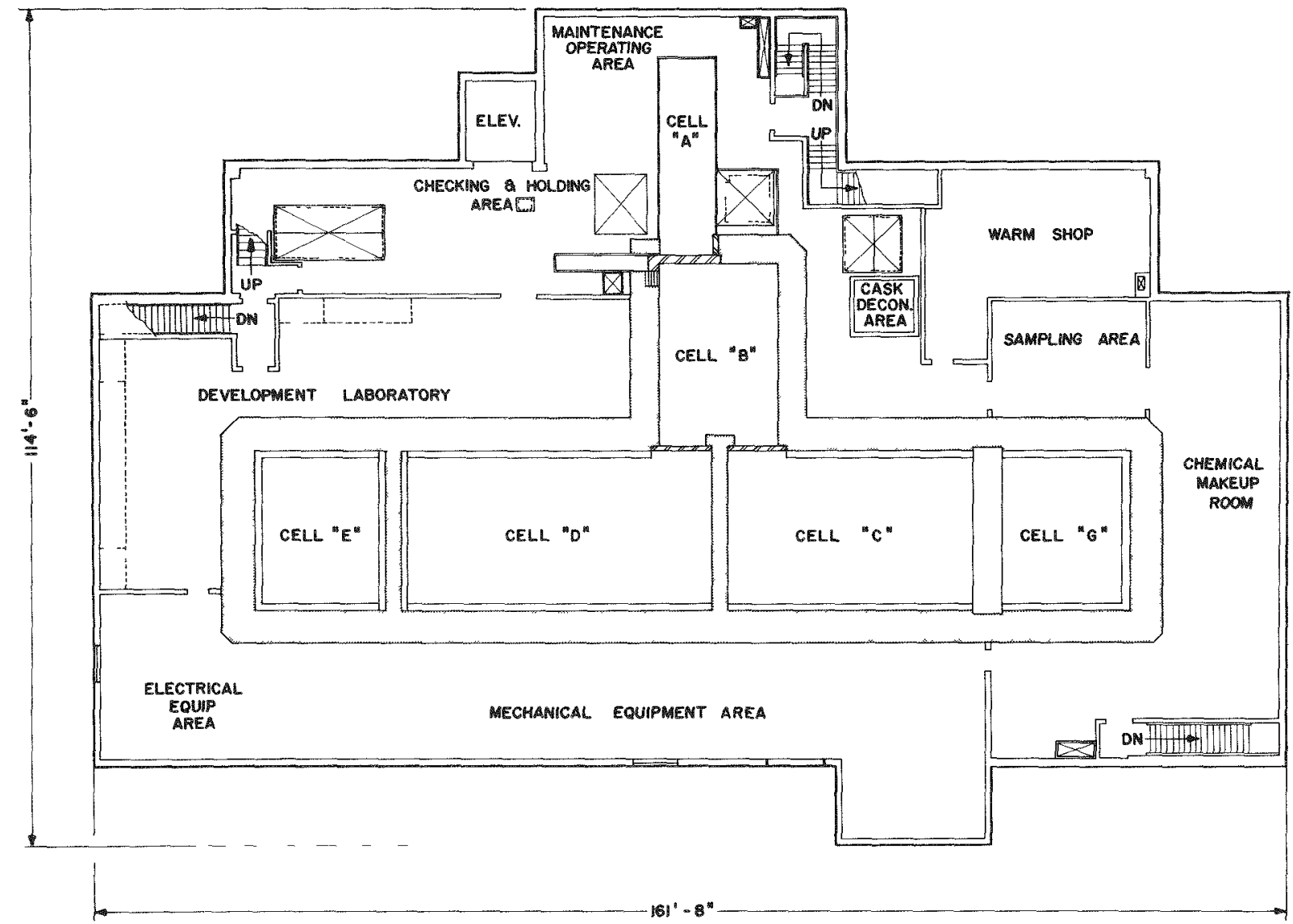

Fig 4. Second Floor Plan of Building 7930 (TURF). 
ORNL DWG. 64-3335RI

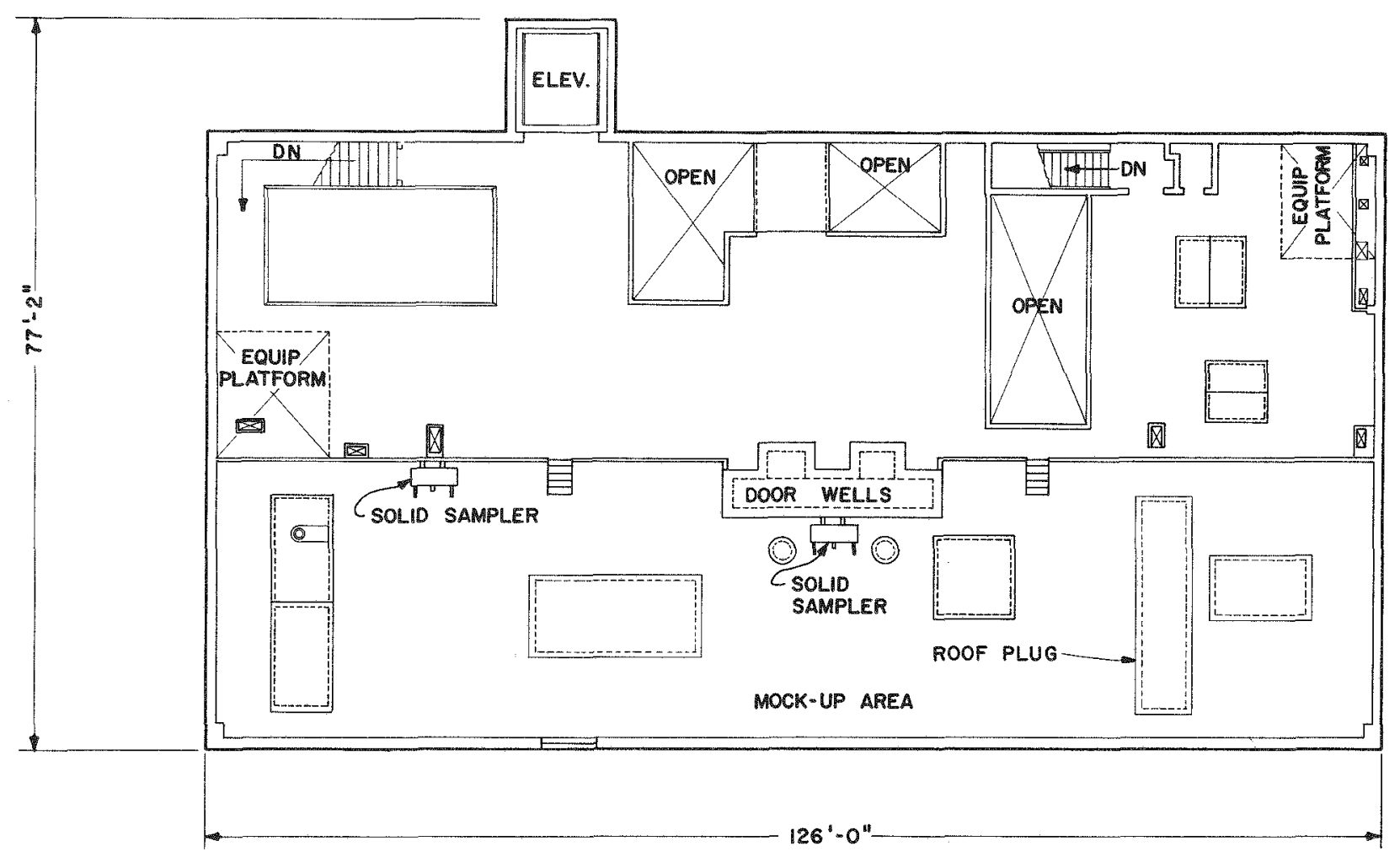

Fig. 5. Third Floor Plan of Building 7930 (TURF). 
The facilities for receiving, handing, and storing radioactive aterials consist of six heavily shielded cells served by an overhead crane and electromechanical manipulator system along with aster-slave manipulators. In addition, there is an unshielded gloved mintenance cell, a fuel storage room with a deep water-filled basin and a cask support and decontamination a rea.

\section{1._TURE_Ce11 Bank}

The hot-cell structure, shown in Pigs. 6 and 7 , is in the shape of a "T". This structure is comprised of one straight section hose exterior dimensions are about 127 ft long. 31 ft wide, and 29 ft high, excluding the cell pit areas, and a second stralght section about $27 \mathrm{ft} 1$ ong. $24 \mathrm{ft}$ wide, and 27 ft high that is perpendicular to and abuts the first section. Aightly shielded (2 ft thick) equipment storage cell about $15 \mathrm{ft}$ mde, $37 \mathrm{ft}$ long. and $13 \mathrm{ft}$ high is adjacent to the 1. oner elevation of the bulk of the structure.

The four operating cells have a 115 of normal concrete that are $5.5 \mathrm{ft}$ thlick to a height of $11 \mathrm{ft}$ above the floor of the operating area and 4.5 thick from there to the roof. which is 5-ft-thick concrete. Cell B shielding walls are of high-density Barytes concrete or equivalent that are $4 \mathrm{ft}$ thick up to the second floor level and 3 ft thick from there to the ceiling. Ce11 $\mathrm{F}$ has $2 \mathrm{ft}$ of normal concrete shielding for the alls and 3 ft for the ceiling. The effectiveness of each shielding window is essentially equivalent to that of the concrete 11 in which it is installed.

All cells are ventilated by air dramn from the occupied areas of the building through absolute" type air filters and thence through the celis on a once-through basis. Whe cell ventilation system is jllustrated schenatically in Fig. 8. The absolute filters on the cell air inlets and specially designed check valves prevent the flov of containated gas from the cells back to the occupied areas in the event of an accidental increase in cell pressure. Air leaving the cells passes through high-capacity roughing filters at the point of exit. It is then directed through to banks of absolute filters in series and released to the atmosphere from the 265-ft-high HFIR stack.

The areas of the TORF that 111 contain appreciable a wounts of fissile material or radioactivity are designed to resist tornado and seismic occurrences. These areas are (1) Cells $B, C$ D. F. and G: (2) the liquid waste tank pit: (3) the fuel storage pit: and (4) the cell ventilation filter pit. 


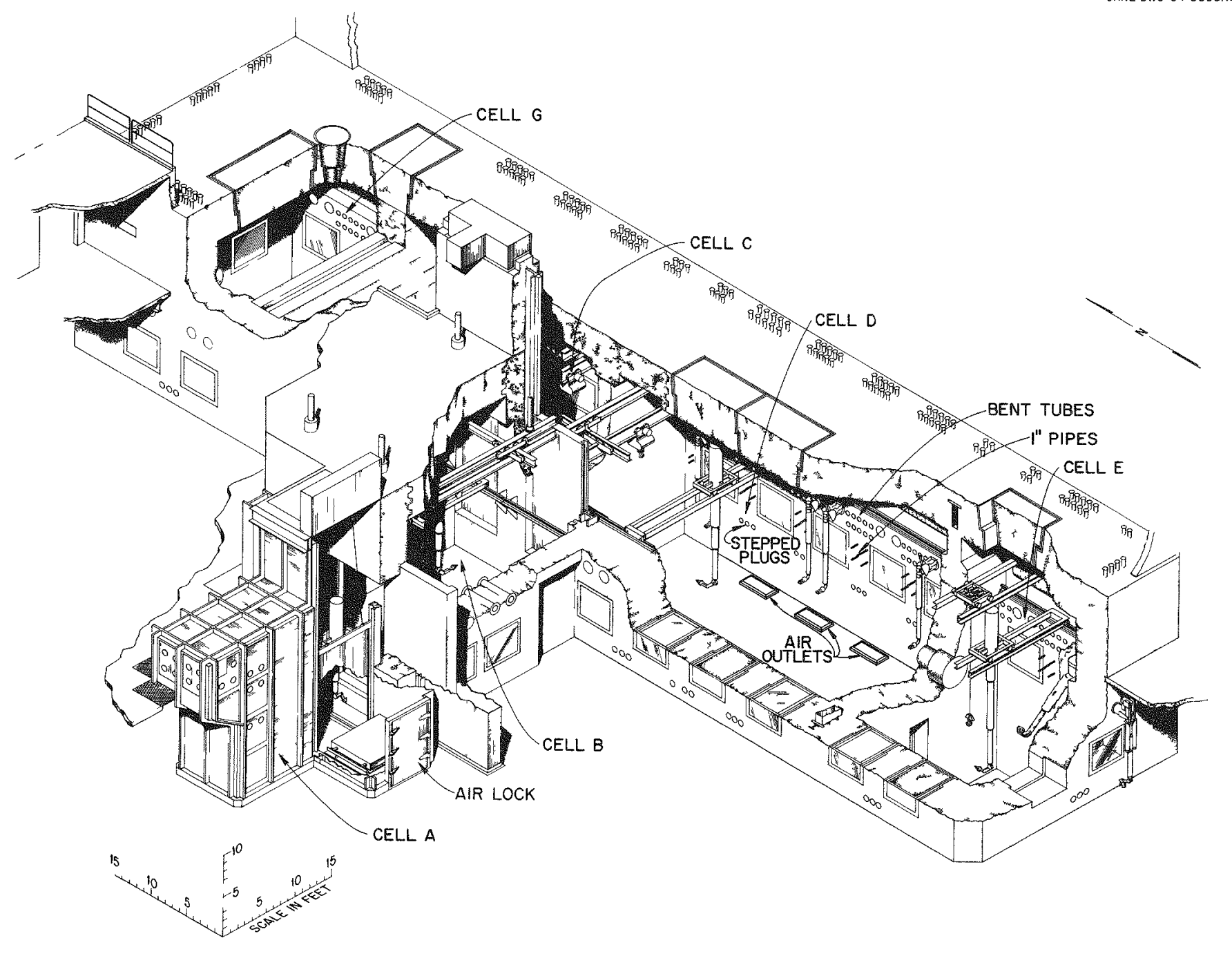

Fig. 6. TURF Cell Bank (BUILDING 7930). 
ORNL-DWG $68-13847$

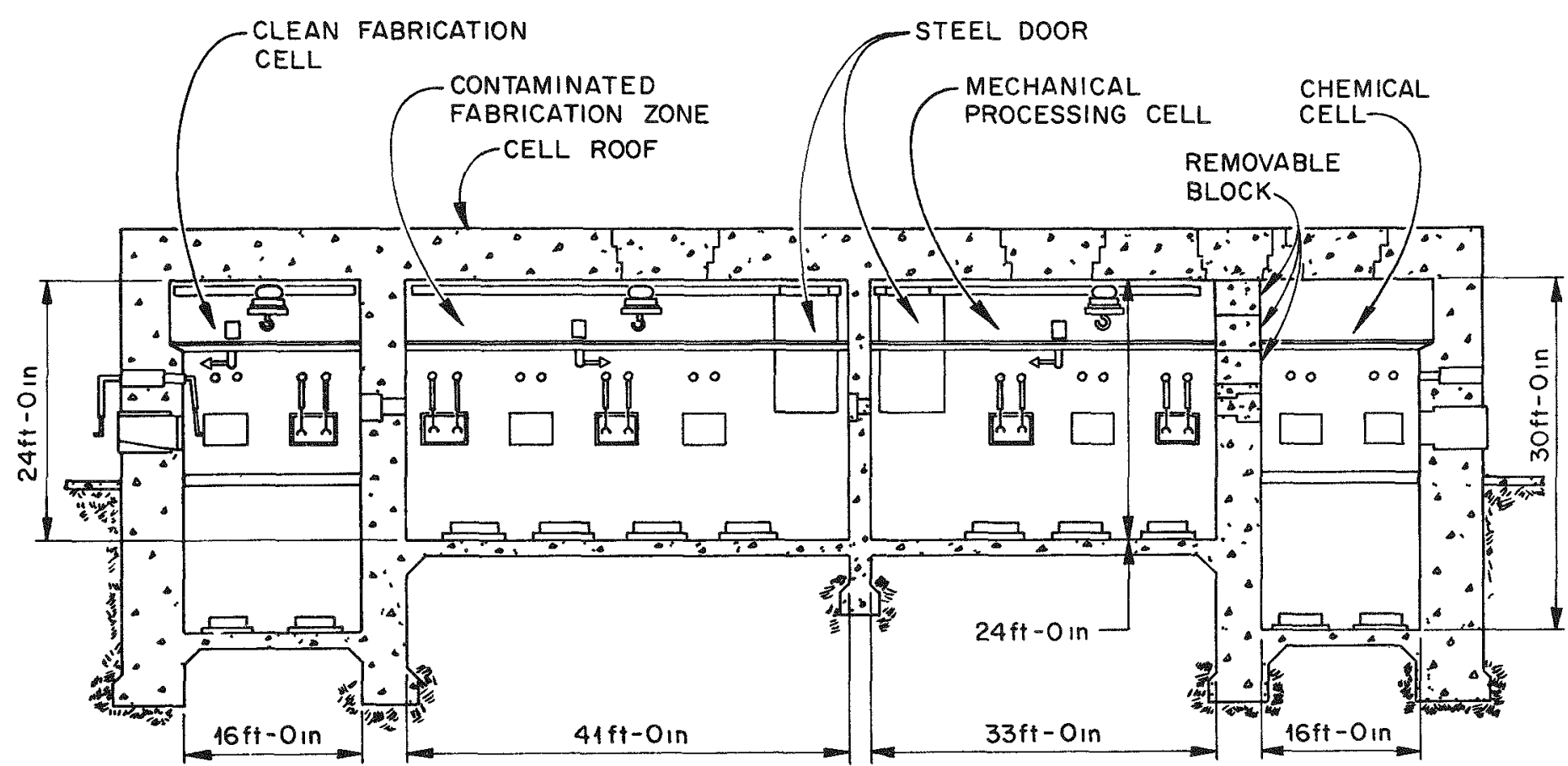

Fig. 7. Elevation View of TURF Operating Cells. 


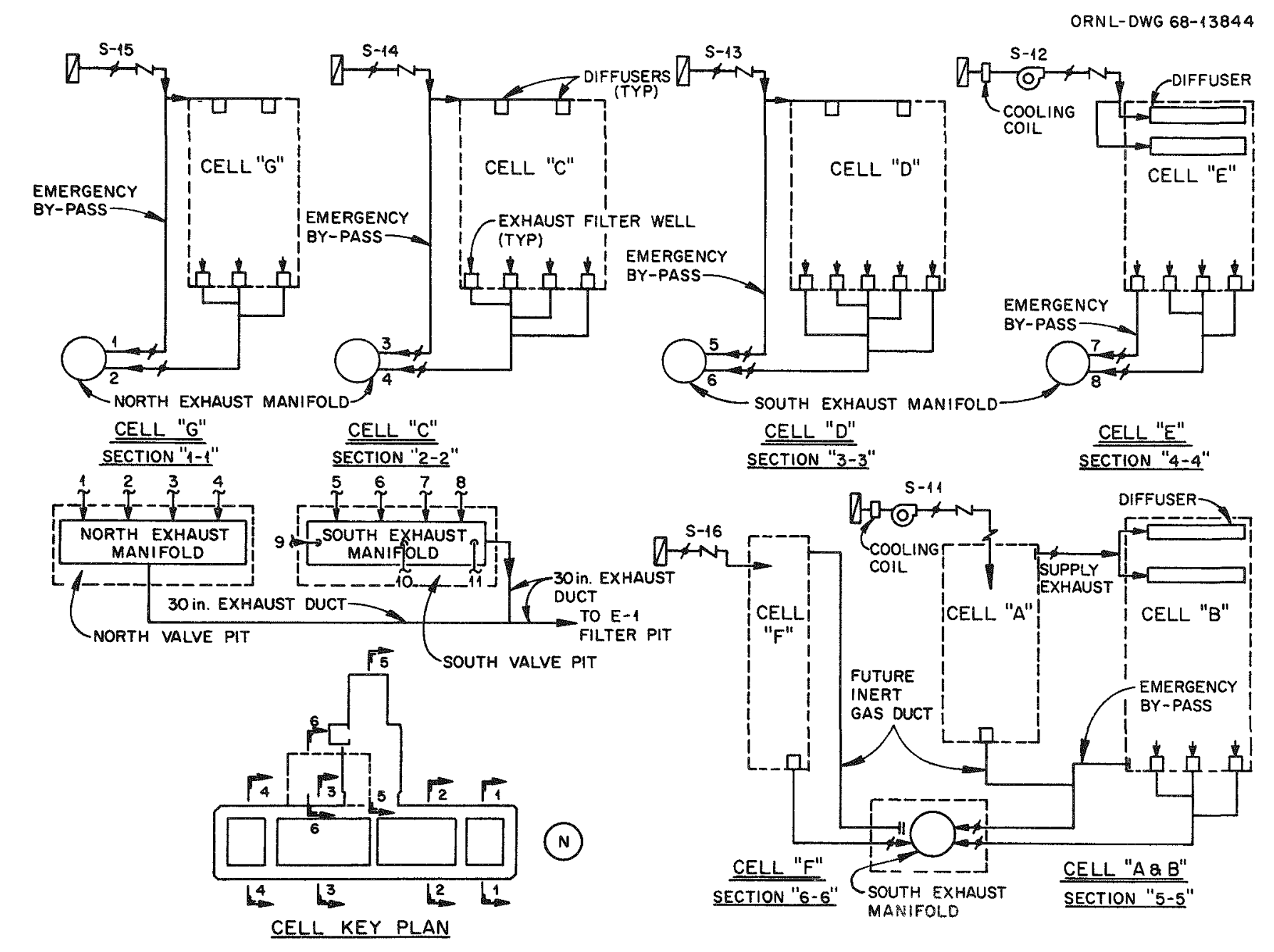

Fig. 8. Schematic Diagram of TURF Cell Ventilation System. 
2. Design Basis for Cell shielding

The radiation source that was used as a design basis for shielding calculations for the TuRF cells was a fuel element containing $35 \mathrm{~kg}$ of araniug-233-thorium mixture, approximately $1.75 \mathrm{~kg}$ of uranium-233 (with $600 \mathrm{ppm}$ uranium-232), and the associated fission products that had been irradiated to 25,000 MD/ton and decayed for 90 days. Based on the assu ption that reprocessing operations are performed with all fission products present, during normal operation, the penetrating radiation dose rate in normally occupied areas (cell operation area. operations office, change room, etc.) would be no greater than $0.25 \mathrm{mrem} / \mathrm{hr}$ ith permissible hot spots in small areas, such as those opposite wa11 penetrations, no greater than $2.5 \mathrm{mrem} / \mathrm{hr}$. In 1 imited access areas not normally inhabited by operating personnel (cell roof area, sampling area, storage cell corridor, etc.). the dose rate would be less than $2.5 \mathrm{mre} / \mathrm{hr}$ with 1 imited area hot spots no greater than 10 times this value. The dose rate in the maintenance operating area and equipment airlock is permitted to be as high as $10 \mathrm{mrem} / \mathrm{hr}$ for short-term nonroutine operation during wich the affected areas are vacated.

Since fission products will have been removed from the feed materials to the proposed pilot plant the penetrating radiation dose rates resuiting from pilot plant refabrication operations will be much lower than those of the TURF design conditions.

\section{B. HTGR Fue1 Refabrication Pilot Plant}

The HTGR Fuel Refabrication Pilot plant will be made up of all equipment. facilities, and services necessary to prepare fuel elements meeting HTGR specifications from recycled fuel, including fuel refabrication processing, waste treatment and disposal, and material handling.

The fuel refabrication processing steps include sol preparation, microsphere preparation, microsphere coating. fuel rod fabrication, and fuel element assembly. 11 processing equipment for the proposed pilot plant will be installed in existing processing cells and adjacent facilities in the TURF. Building 7930. The existing celis are designed to accommodate the processes in rolved, and major modifications to these cells will not be required. The product, terials involved, and the processing operations performed in the major systems or units of equipment in the pilot plant are described in the following subsections. 
1. HTGR_Fuel Element and Fuel

The fuel element for the reference 1160-Mw (e) HTGR is a hexagona 1 block of graphite approximately 31 in. 1 ong and 14 in. across the flats, as shown in Fig. 9. These fuel elements ill be stacked in a closely packed array in both the reference HTGR and the Fort st. Vrain HTGR (PSVR) currently nearing comercial operation. No supporting structure or additional oderator material is needed. The typical fuel element for the FSVR contains 108 heliu coolant holes and 210 fuel holes, hereas the typical fuel element for the 1160-M (e) HTGR contains 72 coolant holes and 132 fuel holes. A slight1\% odified fuel element, shown in Fig. 10, contains large holes for the control rods.

The startup fuel used in the HTGR is in the form of ceramic kermels (microspheres) coated wh pyrolytic carbon and silicon carbide and bonded into rods that fit into the fuel holes in the graphite blocks.1 The coatings on the kernels prevent the release of all but inute quantities of fission products to the reactor coolant system. An inner layer of loy-density pyrolytic carbon is applied to all kernels to provide voids for the fission products and to protect the outer coating from fission recoil damage. The outer layers, which ay be either a single layer of high-density pyrolytic carbon or a layer of silicon carbide sandwiched between two layers of high-density pyrolytic carbon (which is the coating used in FSVR fuel), act as a pressure ressel to contain the fission products. The silicon carbide coating on the startup fissile particles used in the 1160-MW(e) HTGR serves as an effective diffusion barrier to some fission products and also keeps fissile particles intact during the early stages of head-end reprocessing.

Although the fuel elements are similar in design with respect to geometry and dimensions, three types of elements may be used. These three types of elements are classified by the types of particles they contain, and a description of the fuel particle makeup for these three elements is given in Table 1. These three types are (1) the Im element, wich contains uraniu-235 and thorium and is to be used in initial and makeup fuel loadings: (2) the uranium-233 recycle element, which contains uranium-233 and thorium and is to be used as the major recycle element; and (3) the uranium-235 recycle element. which contains recycled uranium -2.35 and thorium and is to be used when it is desirable to pass uraniun-235 through the reactor more than once. Iny combination of these elements may be used in any given reactor core. Both the uranium-233 recycle elements and the uraniu- 235 recycle elements must be refabricated remotely.

several types of particles are used to allow for aintaining separation of spent uraniu-235 fro uranium-233 to inimize cross ixing of the uranium-236 ith the uraniu-233 in the recycle fuel stream. The four particle types are one fertile particle and three fissile particles; a 


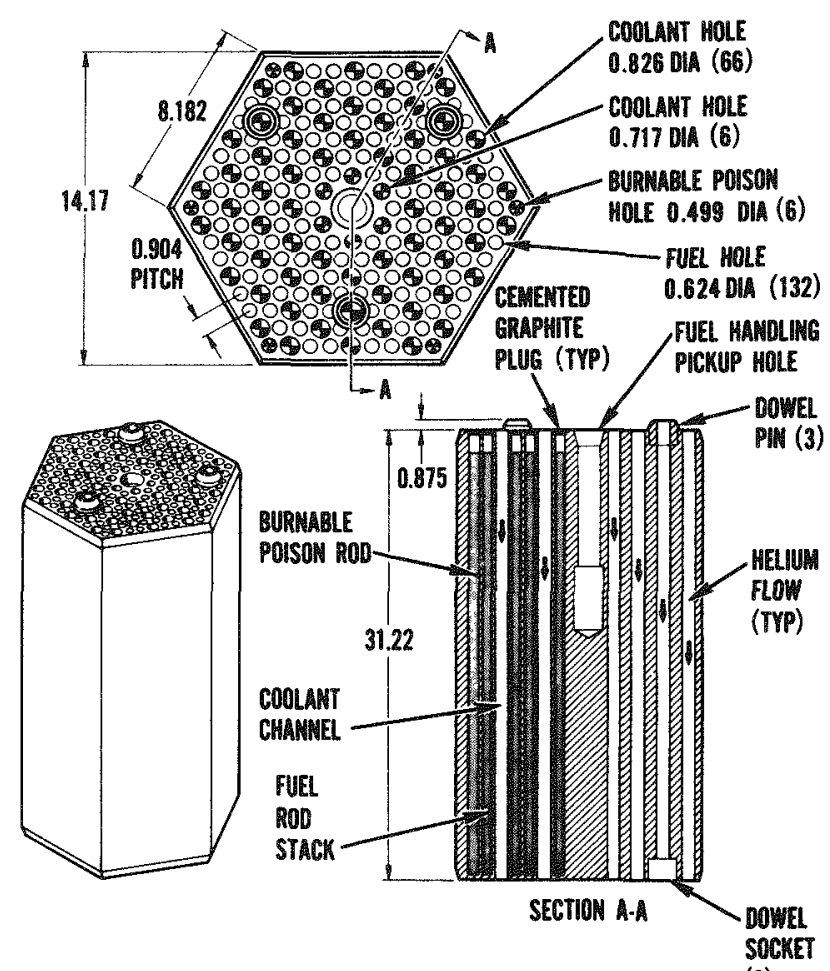

(3)

Fig. 9. Typical 1160-MW(e) HTGR Fuel Element.

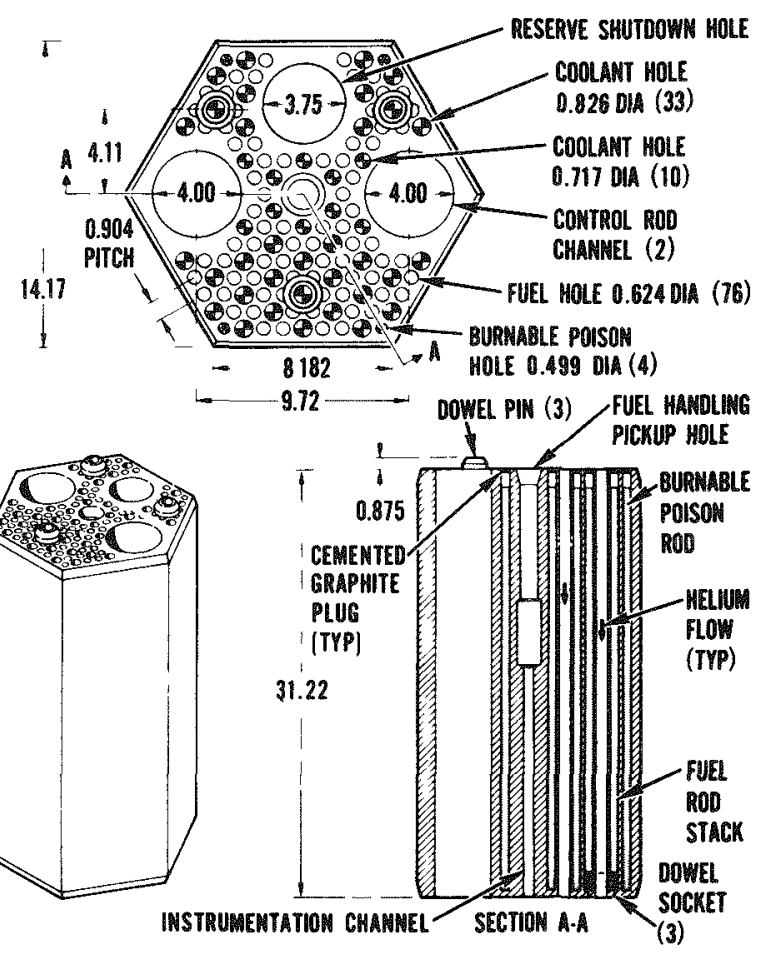

Fig. 10. Typical 1160-MW(e) HTGR Fue1 Element With Control Rod Passage. 
Table 1. HTGR Reference Fuel Particle Descriptions ${ }^{a}$

\begin{tabular}{|c|c|c|c|c|c|c|}
\hline \multirow[b]{2}{*}{ Property } & \multicolumn{2}{|c|}{$I M^{b}$ E1ements } & \multicolumn{2}{|c|}{${ }^{233} \mathrm{U}$ Recycle Element } & \multicolumn{2}{|c|}{${ }^{235} \mathrm{U}$ Recycle Element } \\
\hline & $\begin{array}{l}\text { Fissile } \\
\text { Particle }\end{array}$ & $\begin{array}{l}\text { Fertile } \\
\text { Particle }\end{array}$ & $\begin{array}{l}\text { Fissile } \\
\text { Particle }\end{array}$ & $\begin{array}{l}\text { Fertile } \\
\text { Particle }\end{array}$ & $\begin{array}{l}\text { Fissile } \\
\text { Particle }\end{array}$ & $\begin{array}{l}\text { Fertile } \\
\text { Particle }\end{array}$ \\
\hline Isotope & $235 \mathrm{U}$ & $\mathrm{Th}$ & ${ }^{233} \mathrm{U}-\mathrm{Th}$ & Th & $235 \mathrm{U}$ & Th \\
\hline Kernel Composition & $\mathrm{UC}_{2}$ & $\mathrm{ThO}_{2}$ & $(4.25 \mathrm{Th}, \mathrm{U}) \mathrm{O}_{2}$ & $\mathrm{ThO}_{2}$ & $\mathrm{UC}_{2}$ & $\mathrm{ThO}_{2}$ \\
\hline Kerne1 Diameter, $\mu \mathrm{m}$ & 200 & 500 & 400 & 500 & 200 & 500 \\
\hline Type Coating ${ }^{c}, d$ & TRISO & BISO & BISO & BISO & TRISO & BISO \\
\hline $\begin{array}{l}\text { Coating Thickness, } \mu \mathrm{m} \\
\text { Buffer Carbon } \\
\text { Inner Dense Carbon } \\
\text { Silicon Carbide } \\
\text { Outer Carbon }\end{array}$ & $\begin{array}{l}85 \\
25 \\
25 \\
35\end{array}$ & 85 & 90 & 75 & $\begin{array}{l}85 \\
25 \\
25 \\
35\end{array}$ & 75 \\
\hline Total Particle Diameter, $\mu \mathrm{m}$ & 540 & 820 & 740 & 820 & 540 & 820 \\
\hline
\end{tabular}

a Particles will be bonded into fuel sticks for insertion into hexagonal graphite block fuel elements.

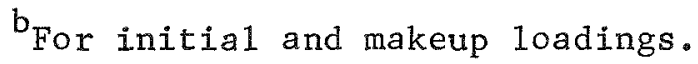

${ }^{c}$ TRISO designates three types of coatings of the kernel: buffer, silicon carbide, and dense pyrolytic carbon.

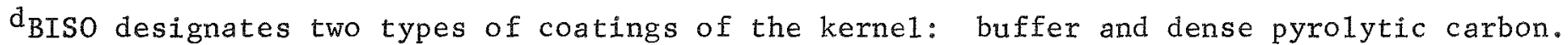


fissile particle containing new uranium-235 with both pyrolytic carbon and silicon carbide coating, a recycle uranium-235 particle containing recycled uraniu -235 coated with both pyrolytic carbon and silicon carbide, and a recycle uraniu-233 particle containing uranium-233 and thorium ith only pyrolytic carbon coatings. only one type of fissile particle is used in any one fuel element. Pissile particles are mixed ith fertile particles before the fuel rod is formed.

\section{Uranium Feed material}

The uranium-233 il1 be received at the National storage Facility for Uranium-233. Building 3019, at ORN in the form of utaniu nitrate or oxide. The received material ill be stored. dissolved if necessary. purified, and transferred from Building 3019 to the ToRF as a uranyl nitrate solution. Receiving. storing, dissolving then necessary. and purifying of uraniui-233 are an integral part of the storage operations performed in Building 3019. - The uranium feed material delivered to the pilot plant 11 be a solution ith a uranium concentration of 100 to $250 \mathrm{~g}$ per 1 iter that will contain less than 0.5 molar nitric acid hen $0=100$ g/1iter, uranium-233 ith less than 1000 ppm of uranium-232, and uranium-233 recently purified from uraniu- 232 daugher products.

\section{Uraniug Feed Material Transfer}

The uraniu feed materia1, purified uranyl nitrate solution, will be transferred frow the National storage Facility for uraniu -233 at ORl. Building 3019 . to the TURP in a specially designed carrier wich will be transported by truck and lowbol trailer.

The carier in which the feed material is transported is a stainless steel toroid shielded with Barytes concrete. The 2-in.-thick ertical toroidal interior portion of the carrier is $46 \mathrm{in.} \mathrm{high} \mathrm{and} \mathrm{has} \mathrm{an} \mathrm{inside} \mathrm{diameter} \mathrm{of} 38$ in. and a maximu capacity of 174 liters. The toroid is covered with a thin cadmiu sheet, the Barytes concrete contains cadiuiu fines and the top and bottom planes of the toroid are enclosed by a stainless steel werane filled ith parafin. gloved box of 1/2-in.-thick steel plate is affired to the top of the carrier. This gloved box has 8-in.-diameter glove ports, and it contains the internal piping necessary to ake and break all feed material connections under double containuent conditions. Steel gussets have been installed on the carrier to protect the covered gloved box if the carrier should be involved in an accident.

The solution carrier will be filled with feed aterial at the loading station at Building 3019. The loaded carrier 11 be transferred to the truck trailer to which it wil be 
secured before the trailer is moved. for transport to the TORF. After the carrier has been transported to the TuRF. It 111 be removed from the trailer and transported into the TURF through existing air locks ith existing building cranes and deposited at the transfer station on top of the processing cell for unloading. vnloading of the carrier at the transfer station ill be accomplished by applying vacuum to the storage tanks located in the processing cell.

Both Building 3019 and the TUR have a transfer station which affords maintenance of double containment during a feed material transfer operation. Each of the transfer stations contains the in process lines for filling and emptying the carrier as well as the services required to leak test the transfer lines. effect the transfer, and then flush and dry the transfer lines. The gloved box on the carrier is connected to the radioactive off-gas system at each station. whe carrier is positioned on a vable platfor for transfer operations to provide the controlled ovement reguired to join the carrier piping with the station piping.

This transfer systen is patterned after the existing procedure used at oRII for the transfer of high-level wates from the Transuraniur Processing plant (TRU) that has been used satisfactorily at ORNI for several years without incident.

\section{4._-_uel_Refabrication_Processing}

The uraniu nitrate feed solution to the pilot plant ill be mixed with virgin thoriu nitrate solution prepared in facilities at the pilot plant. The ratio of thoriu to uranjum can range from 0 to 20. Typically, they are mixed in a ratio of 4.25 parts thoriu to 1 part uranium and reduced to a stable thorium dioxide-uraniu trioxide sol by an anine extraction process (sol preparation). The dilute sol is concentrated by evaporation and passed down through a tapered colum countercurrent to upward flowing 2-ethy1-1-heranol (2-zil) to form gel microspheres ith diameters of approximately 500 microns. The icrospheres are then dried and fired to form dense thorium dioxide-uraniun dioxide spheres (microsphere preparation): After dring and firing. the diameter of the icrospheres is approximate17 350 microns. Alow diagram of these two processes is shown in Engineering Drawing $\mathrm{F}-11416-\mathrm{EP}-001-\mathrm{E}$, hich is given in Appendix $\mathrm{E}$.

Before coating, the microspheres are inspected. sorted, and weighed, and those which exceed out-of-roundness. size. or density tolerances are removed. The refected icrospheres are recycled. The accepted icrospheres are transferred to a fluidized-bed furnace here they are first coated ith a buffer layer of porous carbon by treatwent ith a ixture of acetylene and inert gases, and then they are coated ith a dense and i pervious layer of pyrolytic carbon by treatient with propylene, proprane, or methane (microsphere coating 
operation. An intermediate annealing step may be used prior to deposition of the final coating layer on the microspheres to reduce cracking of the coatings under reactor service conditions. After each coating step, a sample of the microspheres is transferred to an inspection station where the microspheres are checked for size, density, coating thickness, uranium-233 content, thorium content, carbon content of the coating, surface conta ination, crushing strength, and heary metal exposed through defective coatings. The uranium content of the soot discharged to the coating furnace gaseous waste treatment system is also determined. The finish-coated microspheres are again sorted and eighed to remove those which do not meet out-of-roundness, size, and density tolerances. Batches from several furnace charges are blended to produce large, homogeneous batches for subsequent operations. fiow diagram of this process is shown in Engineering Draving $-11416-\mathrm{EM}-001-\mathrm{D}$, which is given in Appendix $\mathrm{E}$.

The fissile thoriu dioxide-uranium dioxide microspheres produced in the particle coating operation are blended with virgin thoriu dioxide fertile microspheres, which are produced and coated in facilities outside of the pilot plant. The blended micropsheres are metered into the molds of a multi-stage and multi-function molding machine. The quantity of microspheres in any mold is controlled within $\pm 0.5 \mathrm{~g}$ of heavy metal, and the icrospheres are placed in each mold so that there is no more than 10 variance of heavy metal in any $1-i n$. length of the finished fuel rod. The rods are $1 / 2$ to $5 / 8$ in. in diameter and 2 to $3 \mathrm{in}$. 10ng. The molds and contents are heated, and the microspheres in the molds are embedded in a carbonaceous matrix to form the fuel rod. Embedment is accomplished by injecting a molten mixture of carbon and pitch into the interstices between microspheres under pressure. The molded "green" fuel rods are then heated to high temperature to carbonize the matrix and drive off the volatiles (fuel rod fabrication). Alow diagra of this process is shown in Engineering Drawing P-11416-EM-007-D, which is given in ppendix $\mathrm{E}$.

Ater an inspection step, the fuel rods are assembled in the holes of a machined graphite fuel element block, which is prepared in a facility outside the pilot plant. Mpproximately 2000 fuel rods are required for a single fuel element. The assenbled fuel elements are inspected, packaged, and stored preparatory to ship went to the reactor. A flow diagram of the fuel element assemb1y process is illustrated in Engineering Drawing $\mathrm{F}-11416-\mathrm{E} M-008-D$, which is given in ppendix $\mathrm{E}_{\text {. }}$

\section{Fuel Element storage}

Fuel element storage consists of the transfer of completed fuel elements, including both approved and rejected elements. from the inspection station to dry storage racks in the processing cell. The existing in-cell crane and 
electromechanical mipulator will be used to effect the transfer of the elements for storage.

Dew onstration of the processes will require the

production of about 150 acceptable recycle fuel elements. The estimated reject rate of $1 \%$ for fuel elements and the estimated rejects during initial operation ill result in the need for storage of up to about 165 fuel elements. Sufficient storage space is available in the processing cell to accommodate the pilot plant production rate and shipping rate. based on the assumption that one shipping cask will be used 80 of the time.

\section{Puel_Element Transfer_and shipment}

Fuel transfer and shipment is comprised of the transfer of refabricated HTGR fuel elements from the processing cell into a shielded shipping container or cask (fuel element loadingl and the transport of this loaded cask by motor freight to a reactor or the HTGR fuel storage facility in Idaho (fuel element shipment).

(a) Fuel Element_Loading. The master-slave manipulators, the electromechanical manipulator, and the in-cell crane will be used to transfer the completed fuel elements. one at a time to an element loading station located in the processing cell. Each fuel element will be checked for radioactive contamination, and decontaminated if necessary. prior to application of a protective material around it.

fter application of the protective material, each element ill be transferred into a single-element cask ia a transfer port in the roof of the processing cell. Hoisting of the element into the transfer cask ill be accomplished by means of $a$ hoist built into the transfer cask.

The 50-ton building crane $y 11$ be used to transfer the loaded cask to the shipping casks located on the trailer in the TrRF receiving area. The shipping cask and can will be in the vertical position for loading. The single-element transfer cask will mate with the shipping cask, and the fuel element ill be lowered into a can within the shipping cask by using the hoist built into the transfer cask. op to three fuel elements at a time will be loaded in the shipping cask can by using this procedure. The shipping can will then be sealed, and the shipping cask cover ill be sealed and leak tested in accordance ith procedures described in Ref. 5 .

The shipping cask ili be monitored for contamination and decontaminated if necessary. The shipping cask will be lowered into shipping position and secured on the trailer. The loaded trailer wil then be removed from the TrRF receiving area for shipment. 
(b) Fuel Element-shipment. Shipments of radioactive aterial to and fol nuclear facilities are subject to the Hazardous laterials Regulations of the U.S. Department of Transportation (DOT). Those regulations are published in Title 49 of the code of Federal Regulations (49 CFR 170-189). Additional packaging standards are inposed by the USAEC in its regulations on packaging of radioactive material for transport (10 CFR 71). A11 shipments of refabricated fuel elements vill be made in accordance ith those regulations.

An existing HTGR fuel shipping cask meets the comprehensive package design standards published in both the DOT and the osAEC regulations. The capability of the cask to withstand accident conditions and proof tests vas analyzed in detail, and a design analyis reports as prepared for the cask. This report as reviewed by the USABC, and after USAEC staff concurrence ith the adequacy of the cask design, a specufic container certification was issued for the cask. The design report and the USAC certification were sent to the office of Hazardous Materials. DoT for further reviev and approval. The DOT authorized use of the HTG cask under DOT special Pernit No. 6346.

To insure that the actual HTGR cask, as fabricated. does in fact ineet the approved design, a quality assurance program was established for the mafacturing process. Melds vere nondestructivel tested for integrity. lead shielding as checked for possible voids by using gama radiation sources. and isual inspections were made throughout the fabrication process. The finished cask as leak tested. Detailed inspections are ade before and after each use of the cask to assure that it continues to meet the approved design requirements.

bout 70 round trips frow oak Ridge to the point of delivery will be required to transport the refabricated fuel elements generated during operation of the proposed pilot plant. If delivery to Idaho is assuned as an arerage condition, each round trip ill be about 4600 miles 1 ong. ith the cask loaded one way and empty on the return leg of the trip. Transportation of these elements will have little or no effect on norma 1 trafic flow. The tota 1 contained radioactivity ithin the HGR shipping cask auring any one shipment, based on three fuel elements per shipment, 11 be about 10 curies. No cadiation effects to the environment or the general public are expected during shipments of refabricated fuel elements because of the low level of radioactivity involved and because the shipping cask in which the elements will be transported was designed specifically for this purpose. Experience ith such transport, as reported in Ref. 6. indicates that drivers and handlers 111 receive no exposure above background as a result of transportation of the refabricated fuel elements. 
7._Effluents_and_Solid Wastes

The source terms for the astes that 111 be generated by operation of the proposed HTGR Fuel Refabrication Pilot Plant are given in Tables 1 through $\mathbb{A}$. 4 in Appendix . The data given in Tables 1 through 14 are based directly on data prepared at ORNL for an en ironmental survey of fuel cycles for HTGPS. The radionuclides and chemicals expected to be released in the gaseous and liquid effluents from the proposed pilot plant are discussed in detail in section III.

The TURF is equipped with several systens for handing the liquid and gaseous rastes that ill be generated.7 The 1iquid astes including storm drainage sanitary wastes. process drainage frow sources other than cells, and radioactive process aste streams. are collected by networks designed and installed for this purpose. Nonradioactive process vastes are monitored for contamination and pi ped to retention basins which provide controlled discharge to the environient. The sanitary waste is transferred into the Melton Valley disposal systen, and storm drainage is discharged directly to a natural drain.

The radioactive 1 iguid waste solutions are impounded and treated in either the TURF aste system or in an existing oRN radioactive aste treatwent syster to which the y mal be transferred. The TuR waste systen consists of three type $304 \mathrm{~L}$ stainless steel tank 1ocated in a concrete pit. The 1iquid levels in the tanks and in the sump below the tanks are onitored frequently by operating personnel. A leak in one of the tanks vould be detected prompty by a change in the liquid level in the sump and would be indicated by an alarm on the operating control panel. Any leakage collected in the sump would be pumped into an existing ORNL radioactive waste treatment system.

The gaseous astes are handled by a ressel hot off-gas (HOG) syster and a cell ventilation system designed and installed to safely handie all gases leaving the building. The gaseous astes from the equipment ithin the cells and certain 1 inited-access points ajjacent to the cell bank are handled by, the vessel HOG system illustrated schematically in Pig. 11. This diagra illustrates the ajor features of the systea. including the parallel filters and fans the scrubber pit for possible addition of a caustic cleaner and the tie-in to the E-1 exhaust system to the HFIR stack. Each of the ressel HOG filters illustrated is comprised of two roughing filters and four HEPA (high-efficiency particulate air) filters in series.

The cell ventilation syste is comprised of air supply systens that pass air into the cells where it and any gaseous waste not collected by the HOG system are collected, a filtration syster and an exhaust syster. The cell ventiation syste airflow pattern is illustrated scheratically in Fig. 12. The system flows are as follows. 
ORNL-DWG 68-13853

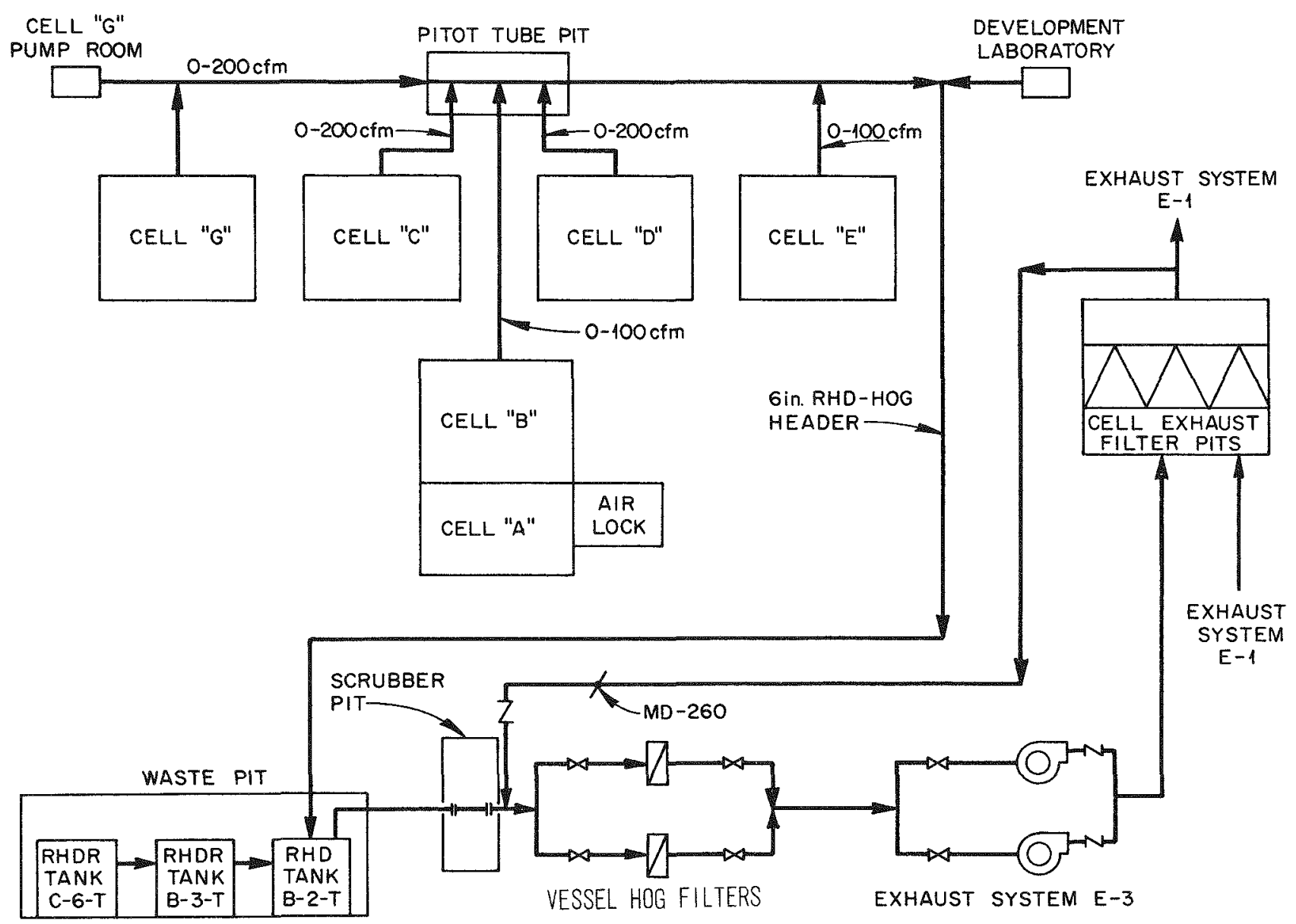

Fig. 11. Schematic Diagram of the TURF Hot Off-Gas Collection and Discharge System. 
ORNL-DWG 68-43859

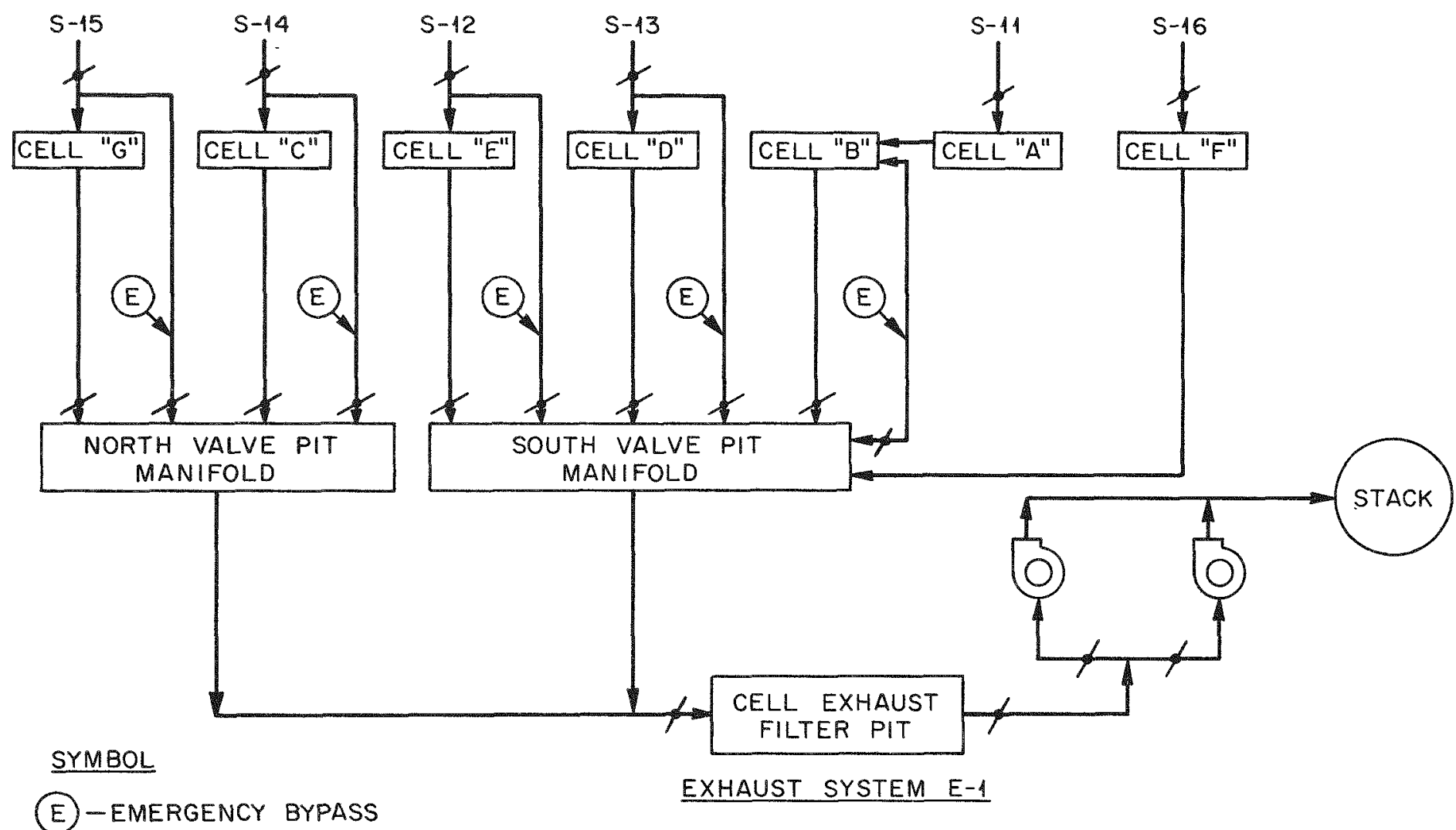

Fig. 12. Schematic Diagram of the TURF Ce11 Ventilation System Airflow Pattern. 


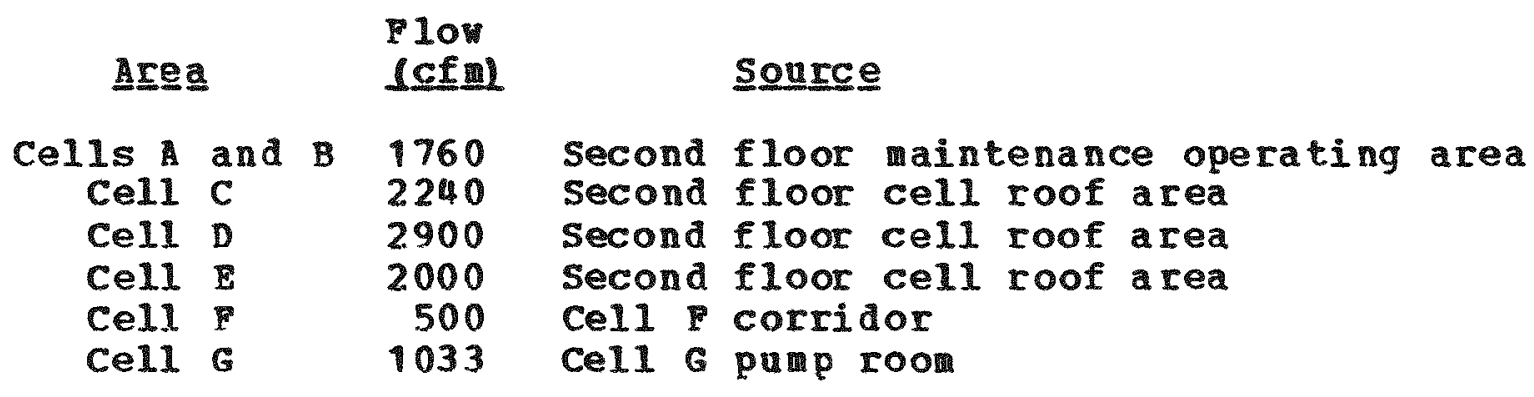

The cell exhaust gas is filtered through high-capacity bag-type dry roughing filters that have a 0.3 -icicron DOP efficiency of $95 \%$. From these in-cell filters, the gas is passed through an absolute filter pit wich contains five parallel compartments, each of wich contains to HeP filters in series. Fron the cell exhaust filter pit, the exhaust gas is discharged to the atmosphere from the HFIR stack, which serves the HFIR. TRU, and TORP. The 265-ft-high HFIR stack has a reported capacity of $60,000 \mathrm{cfm}$ and an estinated average atmospheric dispersion factor of $0.92 \times 10^{-5} \mathrm{sec}^{3} \mathrm{~m}^{3}$ (Ref. 7 ). However, actual measurements of stack flow and atmospheric conditions indicate that a dispersion factor of $2 \times 10^{-7}$ $\mathrm{sec} / \mathrm{m}^{3}$ is more accurate (See Appendix D).

solid astes will be packaged and shipped to the existing ORNL burial grounds and placed in retrievable storage. It is intended that al1 astes generated after the microsphere forming processing step ill be converted to either gaseous or solid wastes.

\section{Possible_Accidents}

Safety in the HTGR Puel Refabrication Pilot plant wil be achieved through the design features inherent to the puRf and the pilot plant processing equipment and by strict administrative control of the operations of the facility and the processing conditions under wich the fissionable or hazardous materials are to be handled. Special safeguards ill minimize the probability of potentially serious accidents involving criticality. fire, or explosion. If these safeguards should fail and such an accident should occur the TURF shielding. containment, and ventilation systems will be capable of limiting the effects of the accident to a minimal level. The safet 1 analysis for the TuR was the basis for assessing the effects of possible accidents.

\section{Project_Decommissioning}

Project decomissioning encompasses the remoral and disposal of al1 HTGR-related equipment fron Building 7930. including equipment from the hot cells, and decontaination of the cells. All surface contamintion will be remored from the 
hot cells to ready thein for the installation of future processes. Detailed procedures will be uritten to provide step-by-step instructions for the removal and disposal of contaminated equipment and support systems and decontamination of the affected cells.

lal_-Deconisionioning_of Remote Processing Cells. A general description of the procedures that wil be required to remove and dispose of contaminated equipment from the remote processing cells and decontaminate the cells is outlined as follows.

1. A11 solid fissile material will be removed from the cells and equipment. The fissile aterial will be stored in the national repository in Building 3019 . A11 solid fertile waterial will be placed in either sealed containers for reuse or in an existing on-site burial ground for future cetrieval.

2. A11 liquid fissile aterial vill be removed from the equipment, and the equipwent 111 be flushed. The liquid fissile material will be reduced in volue by evaporation and stored in the national repository in Building 3019. Al1 liquid fertile aterial ill be removed frol the equipment. and the equipment ill be flushed. This material vill be reduced in volue by evaporation and placed in sealed containers for future use.

3. The equipment 111 be remotely decontaminated in a decontamination cell by using the in-cell crane. electromechanical anipulator. and the aster-siave manipulators. The equipment will then be monitored for beta and gamina radiation.

4. If the radiation level is reduced to an acceptable level, the equipment il 11 be transferred via an existing revotely operated dolly into a gloved alpha cell. The equipment wil then be dismantled. decontaminated further, and monitored for alpha, beta, and gamma radation. If the equipment is clean. it vill have some salvage value. If the equipient is containated, it ill be packaged for long-term storage and retrieval at the existing ORI burial ground.

5. fter all the equipment has been remowed from the cells, the cell alls ceilings, floors, and service piping ill be decontainated remotely by using appropriate decontanination solutions. The cells 111 be decontaminated until no aixborne activity is present and the radiation level is less than 5 iliremp.

6. After remote cell decontamination, personnel may enter the cells and further decontaminate then, the cenaining services. and the disconnect stations. The services and disconnect stations that are contaminated w11 be removed and packaged for long-ter storage and retrieval at the existing ORNL burial ground. Services and disconnect stations that are not containated ill have some salvage value. 
(b) Decomissioning of Ce11E. A general description of the procedures that ill be required to remove and dispose of contaminated equipment from Cell $\mathrm{E}$ and decontaminate the cell is outlined as follows.

1. All solid fissile and fertile material will be removed from cell $\mathrm{E}$. This material will be HTG recycle fuel elements. It is assumed that some of the elements will be acceptable recycle fuel elements, and they ${ }^{11}$ be loaded and shipped as described in subsection II.B.6. However, some will be rejected and broken fuel elements.

The reject and broken elements ill be placed in containers and the containers will be sealed, using the in-cell crane, electromechanical mipulator, and aster-slave manipulators. The containers 111 be remotely leak tested in the cell; it is assumed that the containers will be contaminated. Each loaded container will be removed from the cell and placed in a second container or can, which will be sealed. leak tested, and placed in a shipping cask, as described in Subsection II.B.6. It is assuned that the cans ill be delivered to the HTGR Fuel storage Facility in Idaho for long-ter storage or reprocessing.

2. It is expected that there will be no 1 iguid fissile or fertile material in Cell $\mathrm{F}$.

3. The equipent in cell $\mathrm{E}$ will be remotely decontaminated in place by using an appropriate

decontamination solution. The equipment wil then be monitored for alpha, beta. and gama radiation prior to removal from the cell.

4. The decontaminated equipment will then be removed from the cell via a transfer port in the cell roof and placed in a portable alpha gloved box.

5. The equipment will be dismantled and further decontaminated in the gloved boz. If the equipment is still contaminated, it ill be packaged for long-term storage and retrieval at the ORNL burial ground. If the equipment is clean, it will have some salvage value.

\section{Anticipated Benefits}

The benefits to be derived from the construction and operation of the proposed HTGR Fuel Refabrication pilot plant center on the technology that will be developed and demonstrated. The technical data generated by implementation of the proposed project can be used as a basis for the design and construction of large-scale comercial refabrication plants from which the primary benefits to society and the economy ill occur. The proposed pilot plant ill be designed to test each unit of the processing equipment similar to that to be used in a comercial plant so that the comercial plant will primaril be a scaled-up duplication of the production lines and equip used in the pilot plant. The ajor 
benefits of the pilot plant 111 therefore accrue directly to the comercial refabrication plant, but the benefits that result from the operation of commercial refabrication plants ill benefit the overall U.S. economy.

1. Need_ror Project

The proposed HTR Puel Refabrication pilot plant is intended to provide a basis for the design of comercial refabrication facilities for HTGR fuel. The HTGRs now on order are expected to be discharging uraniun-233 in the early 1980 s. This uraniu ust be stored or it can be reprocessed and refabricated and returned to the ATGRs for power generation. opti ization of economics and resource utilization requires that the uranium-233 be reprocessed. refabricated, and used as fuel.

To recycle fuel from the HTG it is necessary to chemically reprocess the fuel. separate the various fuel materials reconstitute the fuel, refabricate it, and return it to the reactor. The uraniu-233 wich is to be returned to the reactor contains uraniu-232, wich has decal products with high-energy gama radioactivity. Thus, shielded.

facilities and remote operations are required to carry out refabrication operations. It is also necessary that the operations be suitably contained because of high alpha radioactilty associated ith the fuel aterial. The operations and the equiprent reguired for the fabrication of fuel ith uraniu-233 therefore differ greatly from those requiren for fabrication of fuels containing naturally occurring isotopes. There presently is no experience relative to the remote refabrication of HTGR fuels on any scale, and there is very little experience vith remote fabrication of fuels in general. The proposed HTR Fuel Refabrication pilot plant will provide this experience for HFG fue 1.

A study based on data contained in Ref. 8 showed that comercial operation of HTGR fuel refabrication plants should commence in 1985, making it necessary to have the pilot information available by 1978 for design of the comercial plants (based on the assumption that a 7-year period will be required for design construction, and placing of the comercial plant in operation). The ninimu time required to design. construct, and place the pilot plant in operation is 4 years. An aditional 2 pears of pilot plant operation should be allowed for confiration of the design. Therefore, it is seen that operation of the pilot plant should be started in mid-calendar year 1978, and it can be expected to end in mid-calendar year 1980. To a great extent, the design of the comercial plant wil overlap the period of tire during which the pilot plant ill be operated. It is therefore important that he pilot plane be started at an early date to provide the data necessary for the design and construction of the comercial plant on the required schedule. 
2. Scheduuㅛ

The schedule for the HTGR Fuel Refabrication pilot plant calls for the preparation of a definitive conceptual design and the assembiy of criteria for the detailed design of the proposed pilot plant in fiscal year 1974. Completion and approval of the detailed design are scheduled by the end of fiscal year 1976.

The schedule calls for equipment procurement to begin in fiscal year 1976 and proceed vel1 into fiscal year 1977. Equipment installation 111 begin in late fiscal pear 1976 and be completed by the end of fiscal year 1977. Unit and systeis testing ill begin early in riscal year 1977 and be completed by mid-fiscal year 1978. The schedule then allows a 6-1onth period (the latter half of fiscal year 1978) for cold operational testing of the pilot plant. The hot demonstration is scheduled to begin in fiscal year 1979 (July 1978) and be terminated at the end of fiscal year 1980. Shutdown and decomissioning activities are tentatively scheduled for the first half of fiscal year 1981.

The quantity of spent fuel avalable for comercial recycle is dependent upon the schedule for HTGR power plant construction and operation. Pour estimates for future HTGR installations are illustrated in Fig. 13. These estimates range from a conservative total of 20 reactors built between 1979 and 1986 and an optimistic total of 124 reactors built between 1979 and 1988. If it is assumed that comercial reprocessing operations 111 begin in 1986 , the quantity of spent fuel available by then can be estimated from these schedules. When the 20-reactor schedule from Fig. 13 and wass balance data for the reference 1160-W(e) HTGR CYcle with no recycle are used, approximately 473 metric tons of heavy metal will be discharged by the end of 1985. In addition. approximately 182. 174. and 170 metric tons ill be discharged in 1986. 1987, and 1988, respective1y. Approximately $3 \%$ of the discharged heavy metal is fissionable material. Thus, even with the most conservative construction and operation schedule from Fig. 13. a substantial quantity of spent fuel containing significant amounts of issionable aterial ill be ready for reprocessing in the wid-1980s when the first comercial plant is planned for operation.

\section{3.--Benefits_to be Derived}

The HTGR is of interest as an energy syster because of its relatively efficient use of issionable material, its conservation of natural resources through the use of the thorium fuel cycle. its reduced thermal discharge rate because of its high efficiency. its favorable safety characteristics due to the high tenperature capability of the graphite core. the potential for direct cycle gas turbine applications ith dry cooling towers for use in ater-short regions and its 
ORNL-DWG 73-8993

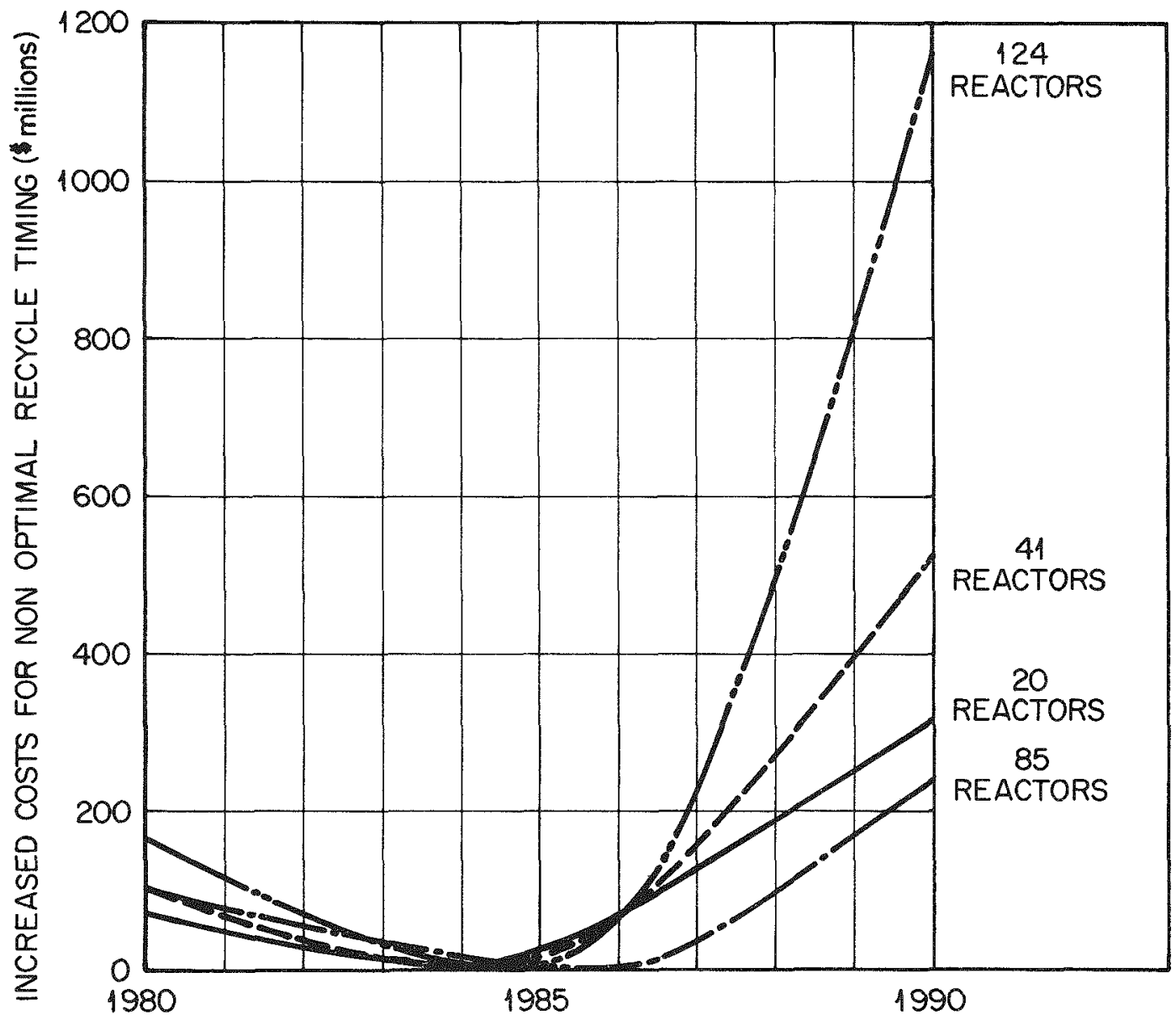

YEAR OF INITIAL COMMERCIAL REPROCESSING

Fig. 13. Influence of Recycle Timing on Fuel Cycle Costs.

potential for high temperature process heat applications. The benefits anticipated from recycling fue 1 in the HTGR are estimated at $\$ 2$ billion in FY 1974 dollars between now and the year 2020 in a reactor economy which includes LWRS, LMFBRs, and HTGRs.

Certain economic and energy benefits will be derived by the overall electrical power production industry from the application of the technology to be developed from implementation of this project. These benefits are described two ways: (1) benefits to the HTGR fuel cycle economy and (2) specific technical benefits from operation of the HTGR Fue1 Refabrication Pilot Plant. 
lal Benefits From Puel Recycle. The benefits to be derived from the recycle of HTG fuel can be determined ith some confidence since HTGRs can be operated ithout recycling fuel and the difference between the cost of recycle and non-recycle operation can be calculated. The results of one study indicate that operation of HTGRs without benefit of recycle increases the fuel cycle costs 0.2 to 0.3 ill/kwhr. Calculations made at ORNL indicate that the benefits of recycling HTGR fuel will be somewat higher. Benefit calculations were made for HTGR economies ranging frol 20 large reactors $1160-1$ (e) beginning comercial operation between 1979 and 1986 to 124 reactors beginning operation between 1979 and 1988, as illustrated in Fig. 13. The HTGR economy recently suggested in ASH-1139, which predicted about $100,000 \mathrm{~m}$ (e) of installed HTGR electrical capacity between 1979 and the year 2000, was also considered. The results of these benefit calculations indicate that the economically optimu time to begin reprocessing spent fuel is calendar year 1984 for the 20 - and 41-reactor econoiles 1985 for the 124-reactor economy, and 1986 for the 85 -reactor economy. sumary of the benefits of recycling for each of these cases determined by comparing calculated fuel cycle costs using optinal recycle uith those for no recycle. is given in Table 2. The fuel cycle expenditures given represent both undiscounted values and values discounted at the beginning of 1978 , using a $10 \%$ discount factor. An inflation rate of $5 \%$ per year was assumed in these calculations. As given in Table 2, the calculated benefit of recycling HTGR fuel is about 0.45 ill/kwhr. The dollar savings varies ith the size of the econory. In addition to decreasing the cost of electric power recycling of HTGR fuel ill save a considerable portion of the uranium reserves thereby benefiting power costs for all reactor designs. Based on the mass balances for the 1160-M(e) HTGR, operation in the non-recycle ode will require about $54 \%$ more uraniu ore and separative work than operation in the recycle ode. Fuel recycling provides the additional benefits realized from not having to build and operate large. expensive storage facilities for spent fuel.

(b) Benefits Prom HTGR Puel Refabrication Pilot plant. The design. construction, and operation of the HTGR Fuel Refabrication pilot plant ill provide infor ation necessary for the scale-up of refabrication processes to comercial plant size. construction and operation of the pilot plant ill enable designers of the systems and equipuent to confirn the design basis and criteria used for the processes remote equipment. and handiing procedures. Changes in the design basis at this stage of development would be relatively inexpensive as compared ith changes in the design basis of a comercial refabrication plant.

Because of the radioactivity of the aterials being processed, it 111 be necessary to design to strict standards 
Table 2. Benefits of Recycling HTGR Fuel

\begin{tabular}{|c|c|c|c|}
\hline Fuel Cycle Cost for ${ }^{a}$ & $\begin{array}{l}\text { Optimal } \\
\text { Recycle }\end{array}$ & $\begin{array}{c}\text { No } \\
\text { Recycle }\end{array}$ & Difference \\
\hline \multicolumn{4}{|l|}{ 20-reactor economy } \\
\hline (a) $\mathrm{mill} / \mathrm{kWhr}$ & 1.13 & 1.58 & 0.45 \\
\hline (b) \$ billions & 2.76 & 3.85 & 1.09 \\
\hline (c) \$ billions & 6.58 & 9.97 & 3.39 \\
\hline \multicolumn{4}{|l|}{ 41-reactor economy } \\
\hline (a) $\mathrm{mil} 1 / \mathrm{kWhr}$ & 1.03 & 1.49 & 0.46 \\
\hline (b) \$ billions & 4.94 & 7.10 & 2.16 \\
\hline (c) \$ billions & 12.03 & 18.80 & 6.77 \\
\hline \multicolumn{4}{|l|}{85 -reactor economy } \\
\hline (a) $\operatorname{mil1} / \mathrm{kWhr}$ & 0.99 & 1.41 & 0.42 \\
\hline (b) \$ billions & 7.42 & 10.66 & 3.24 \\
\hline (c) \$ billions & 21.81 & 33.88 & 12.07 \\
\hline \multicolumn{4}{|l|}{ 124-reactor economy } \\
\hline (a) $\mathrm{mi} 11 / \mathrm{kWhr}$ & 0.94 & 1.38 & 0.44 \\
\hline (b) \$ billions & 12.92 & 19.05 & 6.13 \\
\hline (c) \$ billions & 32.21 & 51.67 & 19.46 \\
\hline
\end{tabular}

${ }^{a}(a)=1$ evelized fuel cycle cost

(b) = present-worthed fuel cycle cost

(c) = undiscounted fuel cycle cost

for protection of operating personnel and the environment. operation of the pilot plant ill permit confirmation of these design concepts prior to their application on a large scale. The levels of quality assurance established during design and construction of the pilot plant ill be tested and upgraded if necessary. for applicability to comercial systems during implementation of the pilot plant program.

operation of the HTGR Puel Rerabrication Pilot plant 111 provide the opportunit to assess the reliability of the processes and equipment required to refabricate HTGR fuel elements. The remote operations that are necessary for refabrication of HFG fuels present a particular proble 1 ith respect to plant maintenance. Operation of the pilot plant vill also provide the opportunity to isolate and solve aintenance probles prior to comercial application of the processes and equiprent.

The product of the HTGR Fuel Refabrication pilot plant wil be a HTGR fuel element containing uraniun-233 for recycle. In conjunction wth the research and development associated ith the pliot plant demonstration program, a number of fuel elements 111 be produced to confirm on a statistical basis that uraniu-233-bearing fuel elements can be transported and irradiated successfully in high-temperature gas-cooled reactors. 
In adition the proposed HTGR Fuel Refabrication Pilot plant wil be of sufficient capacity to permit testing of the economics of remote fuel refabrication processes. Data wil be obtained to establish plant operating factors, equipment reliability. product characteristics, utility requirements. operating labor requirements. aintenance costs, and other pertinent cost factors.

\section{Existing Environgent}

The proposed HTGR Fuel Refabrication Pilot plant 111 be installed in the existing TORF. Building 7930 , hich is located on the USAEC Oak Ridge Reservation at Oak Ridge National Laboratory. as shown in Fig. 1. Nearby facilities include the HFIR and the TRU, as shown in Fig. 2.

Located in the vest central portion of eastern Tennessee. as shown in Fig. 14, the Oak Ridge Reservation is bounded on the northeast, southeast, and southest by the clinch River and on the northmest by Black oak Ridge. The Reservation. established in 1942 by the U.S. Ars Corps of Engineers (Manhattan Engineering District) and stone and Mebster Engineering Corporation, presently covers approvinatel 37,000 acres.

Four separate production and research facilities are operated ithin the Reservation. Three of these Oak Ridge National Laboratory $(X-10)$, the $Y-12$ Plant, and the Oak Ridge Gaseous Diffusion Plant $(\mathrm{K}-25)$. are operated for the USAE by Union Carbide Corporation, Nuclear Division. The Comparative Animal Research Laboratory (CARL) is located along the Clinch River between $X-10$ and $Y-12$, and it is operated by The university of Tennessee. Buffer zones are designated around each of the four facilities for health, safety. and future expansion. Mccess to the Reservation is limited primarily to public roads and isitor centers for reasons of health. safety, and national security.

The area surrounding the Reservation is generally rural to urban in character, with the largest population center (Knoxille population 175.000) located 15 miles to the east. other population centers, all ith populations of less than 35,000 persons, are oak Ridge llocated on the northeast boundary). Clinton (10 miles northeast). Kingston (10 miles southwest). Harriman (10 miles vest), and several smaller comunities ithin Anderson and Roane counties. The cli atology. geolcgy. seismology. ecology of the site. and land use within the Reservation are discussed briefly in the following subsections and in more detail in ppendix $B$. 


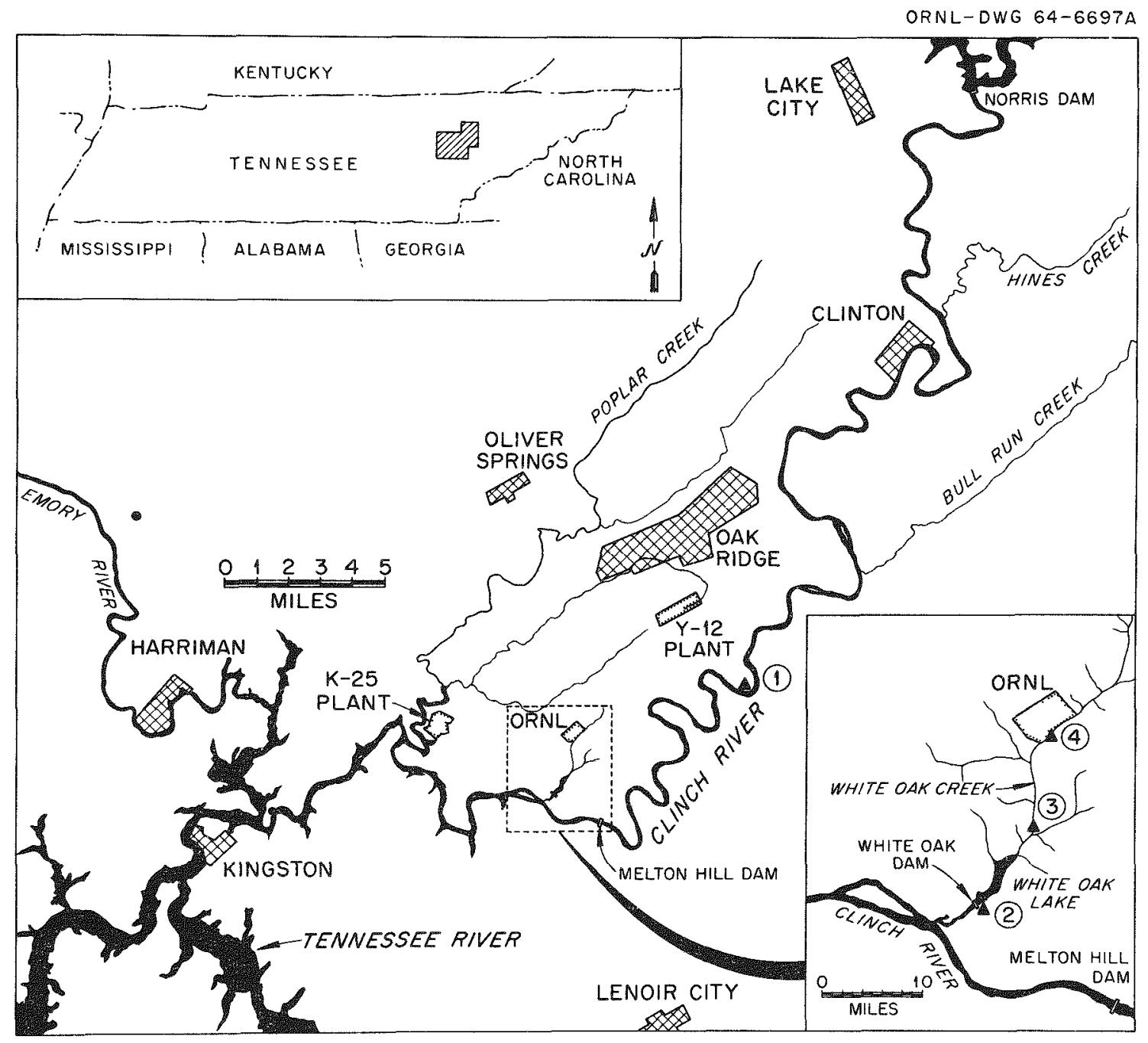

Fig. 14. Location Map of USAEC Reservation at Oak Ridge, Tennessee (numbers in circles indicate stream gaging stations).

\section{Topography and Climatology}

The Oak Ridge site is in the western part of the Tennessee section of the Ridge and Valley province, consisting of parallel ridges and valleys trending northeast. The range in altitude is from 720 to $1335 \mathrm{ft}(220$ to 407 il) above mean sea level.

The climate of oak Ridge is typical of the humid southern Appalachian region. The mean annual rainfall is approximately $53.5 \mathrm{in}$. (136 c⿴囗十). and the mean temperature is 57.9 degrees $F(14.4$ degrees $C)$. Precipitation is predominately in the form of rainfall although under unusual conditions snowfall can represent a significant portion of the total winter precipitation, as happened in the inter of 
1959-1960 when 41.4 in. $(105.2 \mathrm{~cm}$ of snow fell.

stor tracks a ppear to travel from northwest to

southeast. The precipitation pattern during the year is characterized by wet winters and comparatively dry springs followed by relatively vet sumers and dxy autums. July rainfall (5.6 in.) normally approaches that of the wet winter months. While June (4.0 in.) is almost as dry as the autumn months. as is shown in Fig. 15. July is generally the hottest month (76.9 degrees F). while January is the coldest (37.9 degrees F).

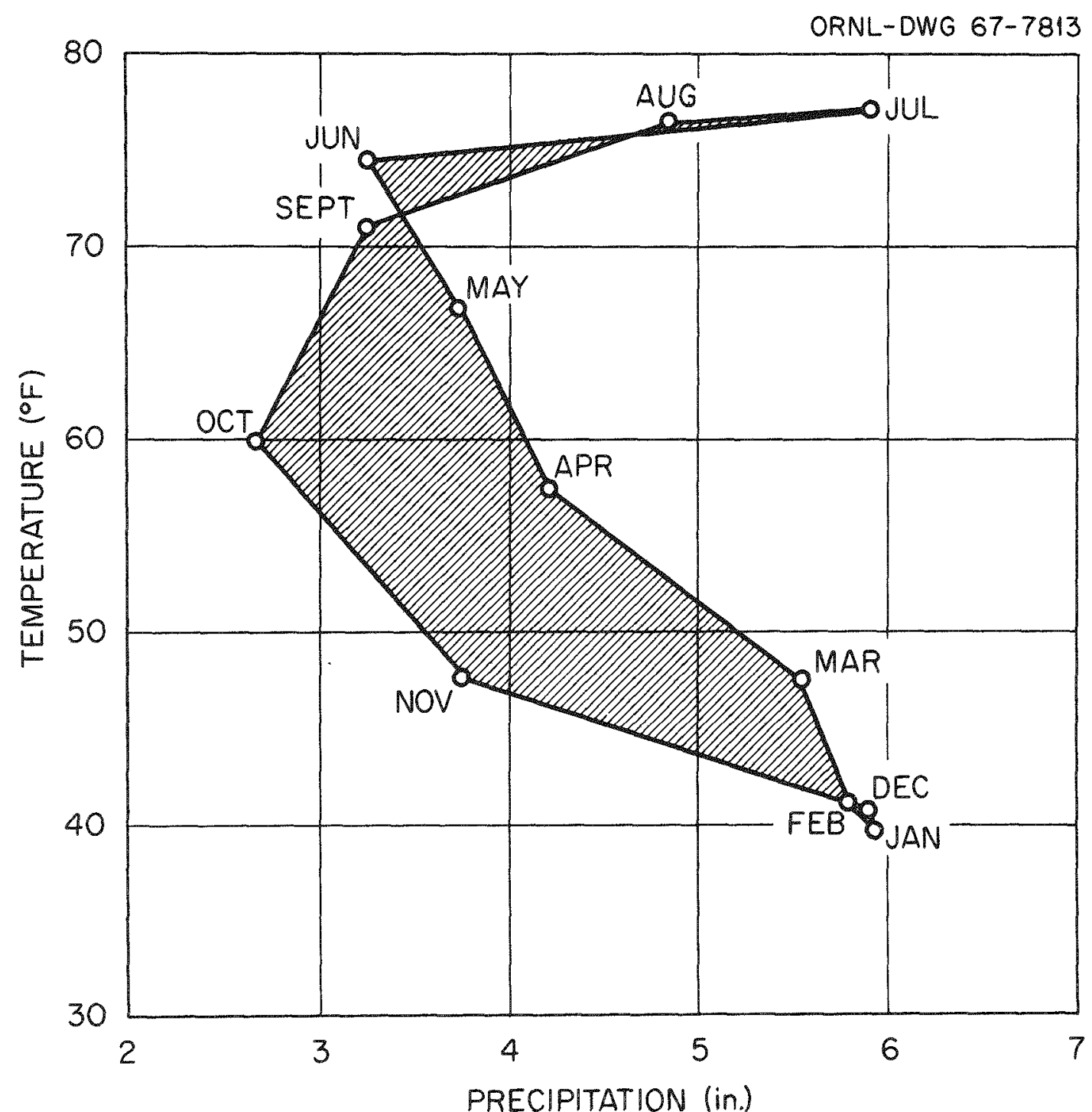

Fig. 15. Climograph of the Oak Ridge Area. 
The striking feature of the oak Ridge climate with respect to plant growth is the development of comparatively early moisture deficits in the spring. However, rainfall in July and August is normally adequate to prevent the development of severe summer deficits. which often occur in other areas of the southern united states. Aditional climatological data are included in ppendix B.

\section{2.-Geology_and soils}

The Oak Ridge Reservation lies in the Tennessee Valley and Ridge portion of the Apalachian Highland physiographic province. This province is characterized by a series of long narrow ridges and slightly broader intervening valleys with a pronounced northeast-southwest trend. The ridges in general are underlain by relativel resistant sandstones and competent limestones or dolomites, wereas the valleys are underlain by weaker shales and ore soluble carbonate rock.

The Thite oak creek basin, upon which the TuRF is

situated, is underlain by four ajor geologic formations. The two oldest. the Rome pormation and the conasauga Group are made up of shale. siltstone, sandstone, and linestone and are poor water-bearing formations. 10 The two younger formations. the Knos Dolomite and he Chickamauga limestone, are the principal water-bearing formations.

The soils of the basin belong to the red-yellov podsolic, the redaish-brown laterite and lithosol groups. These are strongly leached. Low in organic mater, acidic, and generally have exchange capacities less than 10 miliequi valents per $100 \mathrm{~g}$ of soil. Soil profiles cange in depth from $6 \mathrm{in}$. In some shale areas to approximately $15 \mathrm{ft}$ in the dolomite and alluvial areas. clay fractions present include illite. kaolinite. and montmorillinite. with base saturation ranging from 10 to ore than $60 \%$.

\section{H퍼드으이표}

Drainage of the ORHL area is to the Clinch River by way of varions smaller streams. Among these streas is hite oak Creek (Fig. 14). Wich courses through Oak Ridge National baboratory and forms the principal drainage siste for the site. Ground ter levels in the imediate icinity of the TURF range from 25 to wore than $100 \mathrm{ft}$ belov surface contour. These levels undergo marked seasonal fluctuations, reaching peak levels in March and gradually declining as discharge rates exceed recharge rates. 0 Belts of residual aterials overlying bedrock are celatively thin, reducing the volume avilable for groundwater storage. Consequently. it is estimated that the average well in the oak Ridge area would Yield less than 10 gpr. The clinch River, which has a 
drainage area of 4413 square miles, is the source of most of the water used in the area.

Flow in the Clinch River is regulated at Norris Dam and at melton Hill Dam. Stages below Melton Hill Dam a re further affected by operation of ates Bar lake. Pover generation began at elton Hill Dam in the sumer of 1964, and it exerts a significant influence on the flow patterns of the clinch River. Operation of the turbine generators ususally coincides with peak power demands (except on weekends). resulting in intermittent flow releases as high as 18,000 cf s.11

These high flow releases from lelton Hill Da cause water levels to rise rapidly. blocking the outflow of water from White oak creek for about 5 hours each day. White Oak creek is impounded by hite oak Dam. which is a small highway-fill structure located 0.6 miles above the stream mouth where white Hing Road (Tennessee State Highway 95) crosses the creek. The impoundment. White oak lake, covers approximately 20 acres and provides the final on-site monitoring area for liquid effluents from ORNL. Upon cessation of power generation at Melton Hill Dam, the vaters of Wite oak creek begin to flow into the main stream and are flushed downstream with the next power generation flow release. Monitoring stations are located on white oak Creek, on Melton Branch, and on the clinch $\mathrm{River}$.

\section{Seismology}

A seismic risk map of the united states is illustrated in Fig. 16. This pas prepared for use in establishing design requirements for structures to be located in various portions of the country.32 within the southeastern region of the United states, the only zones of highest risk (zone 3) are those around centers of seismic activity in the mississippi Valley and at Charleston. South carolina, both of wich are about 400 miles from the site of the proposed project. The TORF site is in an area of lesser activity assigned a zone-2 risk. indicating a potential for moderate damage. The area has experienced a recent earthquake (November 1973). The epicenter was about 30 miles southeast of the ORNL site, with an intensity of approximately IV - V (modified mercalii). The intensity at ORNL has been estimated at about IV, and there was no observed damage.

\section{5.-_Ecology of Site_and Environs}

The Oak Ridge Reservation is typical of the landscape and ecological systems which occur in the Appalachian Region of the eastern United states. As such, the area is comprised of a number of representative terrestrial and aquatic ecosystems. ranging from smaller, established southern coniferous forests to northern hardwood types and from smaller stream tributaries to man-made reservoir strea $\mathrm{m}$. 


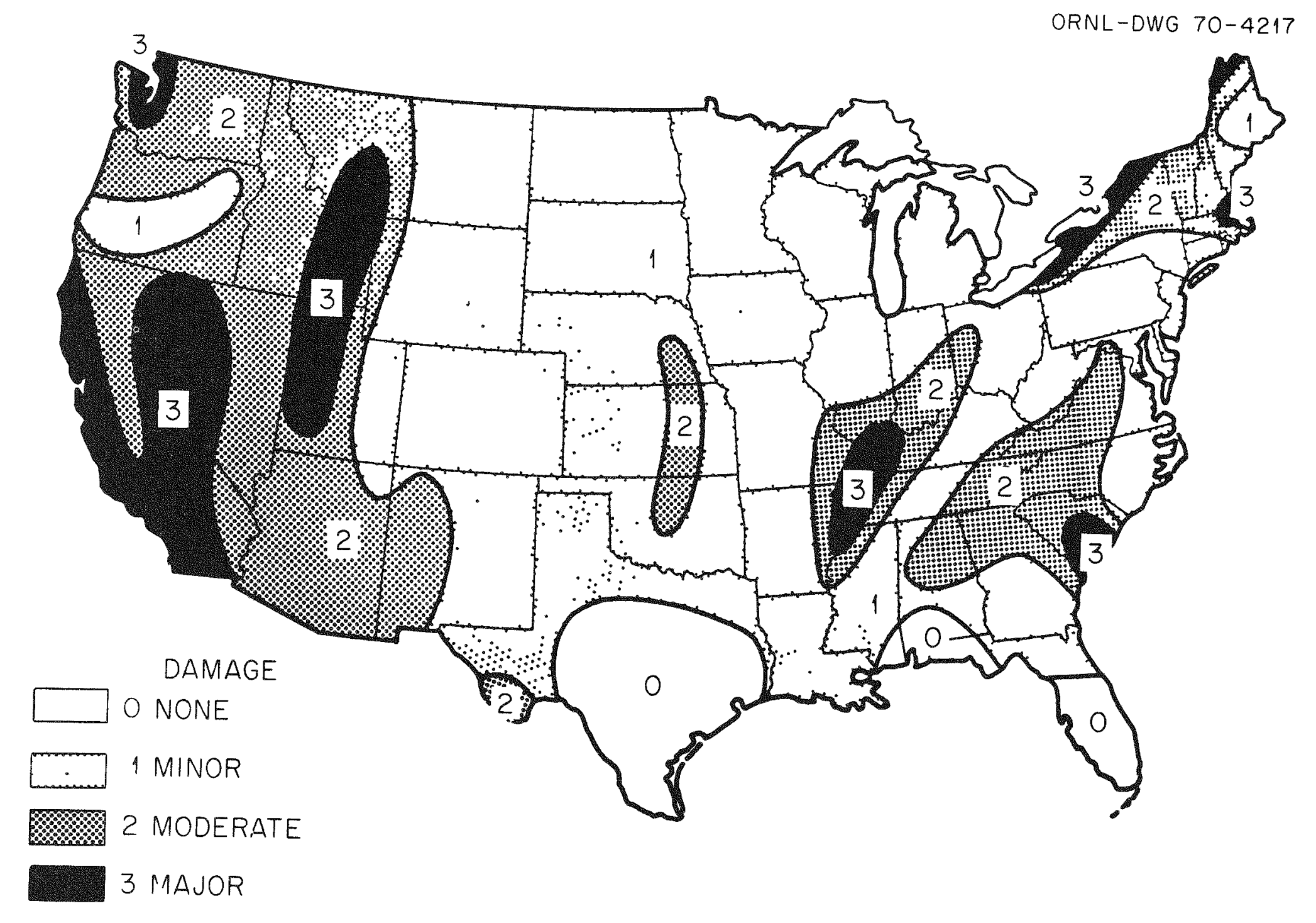

Fig. 16. Seismic Risk Map of the United States (from Ref. 12). 
A prel ininary inventory of the flora of the general oak Ridge area s completed in 1966.13 However, this inventory has since been supplemented ith observations of spring flowering for 171 species of herbaceous and woody plants representing 55 plant families. 14

Five Appalachian forest types are found naturally on the Reservation. 35 The oak-hickory type shares equal prominence with the yellow pine-hardwood type. Cove hardwoods are found interspersed between the dissected ridge systems, and northern hardwoods occur in sheltered areas on northern exposures. A inor type, white pine-hardwood, is found along the northern boundary of the property. Large areas of open land were planted to pine between 1947 and 1956. thereby creating a sixth type.

There are several arailable studies describing the fauna of the area. with special reference to melton valley wherein lies the TuRP. The fauna are typical for forested and semi-forested regions of the united states, and they are described in detail in Appendix B. over 65 separate species of birds were observed in a 1957 sumer survey. The southern bald eagle (Haliaeetus 1. leucocephalus L.) is listed as an endangered species whose range encompasses the local area. 16 However, no recent sitings of the bird have been reported. Typical species of mals include mice. shrews, opossums, racoons, woodchucks, rabbits, foxes, and the white-tail deer.

various facets of the aquatic system, represented by the White Oak Creek. White Dak Lake, Clinch River, and Tennessee River continuum, have been studied over the past two decades. particularly with respect to the behavior and transport of radioactive materials in the aquatic environment. I The biotic composition of hite oak lake is typical of the present aquatic syste downstrea from melton Hill Reservoir and immediately adjacent to the proposed project. Mhite oak lake has been characterized as having high phytoplankton productivity and well developed benthic faun with the most common forms being comprised of various insect larvae. Fishes present in the shallow embayment (maximu depth of $7.3 \mathrm{ftl}$ include bluegill and redear sunfish. largemouth bass. warmouth. gizzard shad, golden shiners, goldfish, and the mosquitofish. Gambusia affinis affinis. The aquatic system is discussed further in ppendix $B$.

6._-_Land_Use

The 92-square-mile Oak Ridge Reservation was originally acquired as a site for production facilities and nuclear research, and a security buffer and safety zone were established around each USEAC plant ithin the Reservation. The original 59.000 acres acquired in 1942 have since been reduced to approximately 37,000 acres through land transfers 
to the unicipal govern went of oak Ridge and to state and federal agencies. 15

The allocation of land ang the USACC users is given in Table 3. Buffer areas around each of the facilities allow for increased securit and protection aginst accidental releases

\begin{tabular}{lr}
$\begin{array}{c}\text { Table 3. Allocation of Land Use Among } \\
\text { Installations in the AEC Oak Ridge Reservationa }\end{array}$ & Acres \\
\hline Administrative Unit & 15,108 \\
\hline Research and Management & 8,843 \\
ORNL & 3,632 \\
Y-12 & 5,645 \\
K-25 & 3,786 \\
UT-AEC & 37,014 \\
Total & \\
\hline & a Data taken from Task Force Report FY-1972 \\
"Surveys of Real Property Holdings," AEC-ORO, \\
June 1972. \\
boes not include 720 acres of UT-AEC farm \\
located within the Y-12 Plant buffer zone.
\end{tabular}

of chemical or radioactive terials and also provide room for future expansion. Lithle forested acreage is included in the buffer areas acound the $1-12$ and $k-25$ plants but extensive forested areas lie within the ORNL $(I-10)$ and UT-AEC (CARI) sections. The remainder of the Reservation (15,000 acres) is approximate1y $95 \%$ forested ith pine (36\%) upland hardwoods (32\%). Wxed pine-hardwoods (21\%), and cedar and miscellaneous speciles $(11 \%)$.

It has recently been proposed that the oak Ridge Reservation be designated an Environiental study park. within this contert, a total of 41 study areas were delineated as being unique and important in terns of present day environental problems. Aditional discussion of historic and present land use is presented in Appendix $B$.

\section{E. onitoring of Existing Environment}

The oak Ridge National Laboratory conducts a continuous monitoring progra on the USEMC-controlled reservation and the surcounding environs. Monitoring network extending 75 miles from ORNL provides information on quantities and concentrations of airborne radioactive pollutants. similarly. a ver and biota onitoring progra is conducted on the 
clinch River. Wich is the eventual receiving body of hater for all potentially contaminated liquid effluents leaving the controlled reservation. A comprehensive, multi-agency investigation of the potential radiation exposures received by the public use of the clinch River waters vas the subject of the 5-year clinch River study. In the final report of this study on the doses to populations from ORNL operations. it was concluded that average exposures were well below the applicable dose 1 imits and that the maximu individual dose vas a sma11 fraction of the dose $11 \mathrm{mits.}$. External gama radiation levels or background levels in the oRN area and in the oak Ridge area are measured coutinely. The background level for the oak Ridge area off the ORNI. site averages approximately 0.012 mer hour, which is about the same as that measured prior to the start of ORIt operations.

Sanitary. chemical, and iscellaneous industrial vaste effluents are mitored through an established environmental surveillance progra which is conducted by the onNL Industrial Hyiene Department and the operations Division. A re detailed description of the environmental monitoring programs for radioactive and chemical effluents is presented in ppendix $C_{\text {. }}$

\section{ENVIRONMENTAL IMPACT}

Construction, operation, and decomissioning of the HTGR Fuel Refabrication pilot plant are expected to hare an insignificant impact on the environment. The construction activity 11 be negligible and concentrations of cadioactive and chemical effluents that ill result from operation of the pilot plant are expected to be several orders of agnitude below established quidelines.20 11 effluents from the proposed profect ill be controlled releases through existing waste disposal systems. The estimated emissions and expected impacts are discussed in the following subsections.

\section{A.-Probable Environmental Effects}

The probable environmental effects of the proposed pilot plant are limited to those that ill result fro discharges to the atmosphere, discharges of ligulds, and solid waste disposal. 
1.-_Discharges to the A tmosphere

All atmospheric discharges from the TORF will be via the No. 7911 stack which also serves the HFIR and the TRO. This stack is 80.8 meters (265 ft) high, and it has an orifice diameter of 1.5 eters and a flow rate of 23.6 cubic meters/sec. At mospheric dilution from this stack is considered in detail in Appendix $D$.

laL-Radioactive Enissions. Meteorological data for the site were used in a computerized atmospheric dispersion odel to esti ate radionuclide concentration as a function of direction and distance from the stack. The derivation of the atmospheric dispersion model, a sumary of the meteorological data. and some results of the calculations are presented in Appendix $D$.

on the basis of actual measurements of stack releases. a dilution factor of $2 \times 10^{-7}$ was used to calculate the maximu radionuclide concentration at the effective perimeter of the facility area. Annul radionuclide release rates and estinated concentrations at the area perimeter are given in Table 4. The concentration guides (CG) 2 for radionuclides in unrestricted areas are also given in Table 4 , and the esti ated concentrations at the effective perimeter are compared ith those CGs. The estimated concentration of each radionuclide at the effective area perimeter is a small fraction of the respective $C G$, the largest fraction being $1.4 \times 10^{-6}$.

The projected radionuclide concentrations at the effective perimeter due to operation of the proposed HTGR Refabrication pilot plant vere used to estimate the radiation dose to an at that location. The resulting dose estimates are given in Table 5. Inhalation is the only exposure mode included for internal dose (radioactive material vithin the body). The intake of radioactivity via terrestrial food chains was estimated to be negligible, being orders of wagnitude less than the esti ated inhalation intake. Discrinination factors for environental transfers of the principal radionuclides that 111 be released to the atmosphere by the proposed pilot plant are on the order of $10^{-3}$ to $10^{-4}$, and furthermore the uptake fractions for those radionuclides following ingestion by man are of similar magnitudes.

The internal dose estimates are based on the dose model used by the International Comission on Radiological Protection (ICRP) in ICRP Publication 2.22 The actual internal dose estimates vere obtained by using INREM, 23 a conputerized version of that dose model. The internal dose esti ates are 50-year dose comitments (50-year dose integration period per year of radionuclide inhalation. The dose comitwent for a radionuclide intake is defined as the total dose an individual ill accrue in his remaining lifetime as a result of that intake. 
Table 4. Atmospheric Releases of Radioactivity to Result From Operation of Proposed HTGR Fuel Refabrication Pilot Plant

\begin{tabular}{|c|c|c|c|c|}
\hline $\begin{array}{l}\text { Radio- } \\
\text { nuclide }\end{array}$ & $\begin{array}{c}\text { Annual } \\
\text { Release } \\
\text { Rate } \\
\text { ( } \mu \text { Ci/year) }\end{array}$ & $\begin{array}{l}\text { Concentration } \\
\text { at Effective } \\
\text { Perimeter } \\
\left(\mu \mathrm{Ci} / \mathrm{cm}^{3}\right)\end{array}$ & $\left(\mu \mathrm{Ci} / \mathrm{cm}^{3}\right)$ & $\begin{array}{l}\text { Ratio } \\
\left(\frac{E P C}{C G}\right)\end{array}$ \\
\hline${ }^{232} \mathrm{U}$ & $1.7 \times 10^{2}$ & $1.3 \times 10^{-18}$ & $9 \times 10^{-13}$ & $1.4 \times 10^{-6}$ \\
\hline${ }^{233} \mathrm{U}$ & $2.5 \times 10^{2}$ & $2.0 \times 10^{-18}$ & $4 \times 10^{-12}$ & $5.0 \times 10^{-7}$ \\
\hline $234 \mathrm{U}$ & $8.0 \times 10^{2}$ & $6.2 \times 10^{-19}$ & $4 \times 10^{-12}$ & $1.6 \times 10^{-7}$ \\
\hline${ }^{235} \mathrm{U}$ & $1.5 \times 10^{-2}$ & $1.1 \times 10^{-22}$ & $4 \times 10^{-12}$ & $2.8 \times 10^{-11}$ \\
\hline${ }^{236} \mathrm{U}$ & $7.3 \times 10^{-1}$ & $5.7 \times 10^{-21}$ & $4 \times 10^{-12}$ & $1.4 \times 10^{-9}$ \\
\hline${ }^{238} \mathrm{U}$ & $7.3 \times 10^{-4}$ & $5.7 \times 10^{-26}$ & $3 \times 10^{-12}$ & $1.9 \times 10^{-14}$ \\
\hline $212 \mathrm{Bi}$ & $4.0 \times 10^{-1}$ & $3.3 \times 10^{-21}$ & $3 \times 10^{-9}$ & $1.1 \times 10^{-12}$ \\
\hline${ }^{234} \mathrm{~Pa}$ & $7.3 \times 10^{-4}$ & $6.2 \times 10^{-24}$ & c & $c$ \\
\hline $212 \mathrm{~Pb}$ & $4.0 \times 10^{-1}$ & $3.3 \times 10^{-21}$ & $6 \times 10^{-10}$ & $5.5 \times 10^{-12}$ \\
\hline $212 \mathrm{Po}$ & $2.6 \times 10^{-1}$ & $2.1 \times 10^{-21}$ & $c$ & c \\
\hline $216 \mathrm{Po}$ & $4.0 \times 10^{1}$ & $3.3 \times 10^{-19}$ & $\mathrm{c}$ & $c$ \\
\hline${ }^{224} \mathrm{Ra}$ & $4.0 \times 10^{I}$ & $3.3 \times 10^{-19}$ & $2 \times 10^{-11}$ & $1.6 \times 10^{-8}$ \\
\hline $220 \mathrm{Rn}$ & $4.0 \times 10^{1}$ & $3.3 \times 10^{-19}$ & c & c \\
\hline $228 \mathrm{Th}$ & $4.0 \times 10^{0}$ & $3.3 \times 10^{-20}$ & $2 \times 10^{-13}$ & $1.6 \times 10^{-7}$ \\
\hline $232 \mathrm{Th}$ & $8.0 \times 10^{-2}$ & $6.2 \times 10^{-22}$ & $1 \times 10^{-12}$ & $6.2 \times 10^{-10}$ \\
\hline $208 \mathrm{~T} 1$ & $1.5 \times 10^{-1}$ & $1.2 \times 10^{-21}$ & $c$ & c \\
\hline
\end{tabular}

${ }^{a}$ Concentration Guide (CG) as stipulated in $10 \mathrm{CFR} 20$, Appendix B, Table II.
$b$ (Effective Perimeter Concentration)/(CG)
${ }^{c} \mathrm{CG}$ values not provided in $10 \mathrm{CFR} 20$.

The total dose estiated for inhalation is thought to be pessinistic for two reasons: (1) the for (soluble or Insolublel assumed for each radionuclide as the one having the greatest dose potential and (2) the reference organ assumed for each radionuclide as the one receiving the highest dose. Because the inhalation dose estimates given in Table 5 represent a ix of fors and reference organs it is very inprobable that any single tissue in the body voul receive a total dose ia inhalation equal to the total given in the table for that exposure mode.

Two modes of exposure are included for external. (radioactive materials outside of the body) dose. They are (1) Imersion in the pluae. and (2) exposure to the contaninated land surface. Factors for converting external 
Table 5. Estimated Dose to Man at the Effective Perimeter of the Proposed HTGR Fuel Refabrication Pilot Plant Resulting from Atmospheric Release of Radioactivity from the Plant

\begin{tabular}{|c|c|c|c|}
\hline \multirow{3}{*}{$\begin{array}{l}\text { Radio- } \\
\text { nuclide }\end{array}$} & \multicolumn{3}{|c|}{ Dose (mrem per year of exposure) } \\
\hline & \multirow{2}{*}{$\frac{\text { Internal }}{\text { Inhalation }}$} & \multicolumn{2}{|c|}{ Externa1 } \\
\hline & & Immersion & Land Surface \\
\hline${ }^{232} \mathrm{U}$ & $2.2 \times 10^{-3}$ & $2.1 \times 10^{-11}$ & $1.2 \times 10^{-6}$ \\
\hline${ }^{233} \mathrm{U}$ & $8.2 \times 10^{-4}$ & $2.9 \times 10^{-11}$ & $1.1 \times 10^{-6}$ \\
\hline${ }^{234} \mathrm{U}$ & $2.4 \times 10^{-4}$ & $8.4 \times 10^{-12}$ & $5.2 \times 10^{-7}$ \\
\hline $235 \mathrm{U}$ & $4.1 \times 10^{-8}$ & $1.5 \times 10^{-13}$ & $1.3 \times 10^{-9}$ \\
\hline${ }^{236} \mathrm{U}$ & $2.2 \times 10^{-6}$ & $6.7 \times 10^{-14}$ & $4.3 \times 10^{-9}$ \\
\hline $238 \mathrm{U}$ & $2.0 \times 10^{-11}$ & $6.0 \times 10^{-17}$ & $3.8 \times 10^{-14}$ \\
\hline $212 \mathrm{Bi}$ & $1.6 \times 10^{-9}$ & $3.2 \times 10^{-12}$ & $1.8 \times 10^{-8}$ \\
\hline${ }^{234} \mathrm{~Pa}$ & $a$ & $1.7 \times 10^{-13}$ & $9.1 \times 10^{-10}$ \\
\hline $212 \mathrm{~Pb}$ & $8.4 \times 10^{-9}$ & $4.3 \times 10^{-12}$ & $2.5 \times 10^{-8}$ \\
\hline 212 Po & $a$ & $b$ & $\mathrm{~b}$ \\
\hline 216 Po & a & $\mathrm{b}$ & $\mathrm{b}$ \\
\hline $224 \mathrm{Ra}$ & $2.2 \times 10^{-5}$ & $2.9 \times 10^{-11}$ & $1.6 \times 10^{-7}$ \\
\hline $220 \mathrm{Rn}$ & a & $\mathrm{b}$ & $\mathrm{b}$ \\
\hline $228 \mathrm{Th}$ & $3.1 \times 10^{-4}$ & $1.0 \times 10^{-12}$ & $2.8 \times 10^{-8}$ \\
\hline $232 \mathrm{Th}$ & $2.6 \times 10^{-5}$ & $6.4 \times 10^{-14}$ & $4.2 \times 10^{-10}$ \\
\hline $208 \mathrm{~T} 1$ & a & $3.6 \times 10^{-11}$ & $1.7 \times 10^{-7}$ \\
\hline Tota1 & $3.6 \times 10^{-3}$ & $1.3 \times 10^{-10}$ & $3.2 \times 10^{-6}$ \\
\hline
\end{tabular}

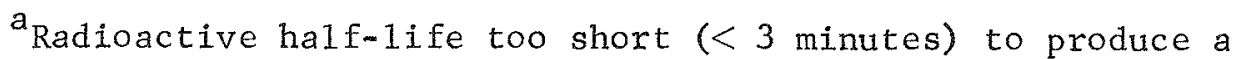
significant dose if inhaled without parent radionuclide.

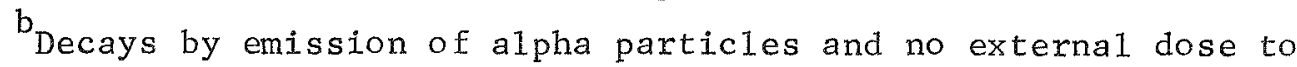
man was computed. 
radiation exposures to dose were obtained by using the computer progran EXREM, 24 hich contains models adapted from standard texts.25-26 The estimates for external exposure are total air dose at the skin surface for all photon emissions. Electron emissions are not included in the dose estimates because of their inor dose contributions to internal body organs. The esti mated external dose values given in Table 5 are for one year of pilot plant operation, and they are assumed to be applicable to total body and all internal tissues for purposes of adding dose estimates for the various exposure modes.

The addition of all of the dose estimates given in Table 5 yields a total dose estimate of $3.6 \times 10^{-3}$ rem per year of pilot plant operation. This small annual radiation dose is expected to have no significant impact on man. The total dose estimate is equal to a very small fraction $\left(4 \times 10^{-5}\right)$ of the annual dose (100 men/year) an normally receives from natural background radiation.

(b) Estinated Dose Exon Lonq-Lived Radionuclides After Project Decomissioning. Individuals and populations ay be exposed to long-1ived radionuclides for several years after the proposed pilot plant has been shut down. The long-lived radionuclides expected to result from operation of the proposed HTGR Fuel Refabrication Pilot plant and the amounts to be deposited during operation of the plant are given in Table 6. The dose comitments per year of exposure to average individuals and he critical organs of individuals are given in Table 7. The population total body dose ithin 70 iles of the proposed project site (the TORF) is estilated to be 9.0 10- man-rem of exposure per year. The radionuclide contributing most of the dose to individuals and to the population is uranium-232, which accounts for $97 \%$ of the dose to the total body and $68 \%$ of the dose to bone and lungs.

(c) Chemica1 Buissions. The chemicals that ill be emitted to the atmosphere as a result of operation of the proposed HTGR Fuel Refabrication pilot plant are given in Table A. 1 of Appendix A. These chemical emissions are discussed individually in the following paragraphs.

Approximately 1.8 metric tons of carbon monoxide (co)

will be discharged from the pilot plant on an annual basis. The esti lated concentration of $c o$ at the site boundary vill be less than $1 \%$ of the national ambient air quality standard 20 established for this gas.

The oxides of nitrogen emitted fron the pilot plant vill amount to about 0.124 metric ton per year. These emissions will result in ambient concentrations equivalent to 0.001 icrogra per cubic meter at the site boundary.

Carbon dioxide hydrogen, and various inert gases such as argon and heliu are natural constituents of the atmosphere. The annial release of 53 metric tons of carbon dioxide. 1.8 metric tons of hydrogen, and 25 metric tons of inert gases 
Table 6. Total Activity of Long-Lived Radionuclides Released During Lifetime of Proposed Projecta

\begin{tabular}{|c|c|c|}
\hline Nuclide & $\begin{array}{c}\text { Radioactive } \\
\text { Half-Life } \\
\text { (Years) }\end{array}$ & $\begin{array}{c}\text { Curies } \\
\text { Released }\end{array}$ \\
\hline${ }^{232} \mathrm{U}$ & 71.0 & $3.4 \times 10^{-4}$ \\
\hline${ }^{23}{ }^{3} \mathrm{U}$ & $1.6 \times 10^{5}$ & $5.0 \times 10^{-4}$ \\
\hline $234 \mathrm{U}$ & $2.5 \times 10^{5}$ & $1.6 \times 10^{-4}$ \\
\hline${ }^{235} \mathrm{U}$ & $7.1 \times 10^{8}$ & $3.0 \times 10^{-8}$ \\
\hline${ }^{236} \mathrm{U}$ & $2.4 \times 10^{7}$ & $1.5 \times 10^{-6}$ \\
\hline${ }^{238} \mathrm{U}$ & $4.4 \times 10^{9}$ & $1.5 \times 10^{-9}$ \\
\hline $228 \mathrm{Th}$ & 1.9 & $8.0 \times 10^{-6}$ \\
\hline $232 \mathrm{Th}$ & $1.4 \times 10^{10}$ & $1.6 \times 10^{-7}$ \\
\hline \multicolumn{3}{|c|}{$\begin{array}{l}\text { Based on a two-year operating period for the } \\
\text { osed pilot plant. } \\
b_{\text {These releases divided by } 3.98 \times 10^{10} \text { give the }} \\
\left.\text { age concentration ( } \mathrm{Ci} / \mathrm{m}^{2}\right) \text { within a radius of } 70 \\
\text { s of the TURF at the time of proposed pilot } \\
\text { th shutdown. }\end{array}$} \\
\hline
\end{tabular}

will have an insignificant effect on natural atmospheric concentrations.

pproximately 7.3 pounds each of surfactant and 2-ethy1-1-hexanol ill be discharged annually. The combined resultant site boundary concentrations of these compounds are estimated at less than 88 millionths of one percent of the national air quality standards for aerosols.

Particulate matter will be removed from all gaseous waste strea $\mathrm{ms}$ through utilization of high efficiency filters vith a removal efficiency greater than $99 \%$. Atmospheric discharge of the remaining particulates, esti mated to be less than 0.0003 metric ton per year, will yield negligible site boundary concentrations of these materials; $0.000004 \mathrm{microgram} / \mathrm{m}^{3}$ as compared with the abient air standard for particulates of 75 icrograms/m.

In sumary, no significant environmental impacts may be identified ith gaseous discharges from the proposed pilot plant. 
Table 7. Estimated Doses From Exposure to Long-Lived Radionuclides

Deposited in the Environment During the Lifetime of the Facility

\begin{tabular}{|c|c|c|c|c|c|c|c|c|}
\hline \multirow{3}{*}{$\begin{array}{l}\text { Radio- } \\
\text { nuclide }\end{array}$} & \multicolumn{8}{|c|}{ Organ Dose (mrem) per Year of Intake or Exposure ${ }^{a, b}$} \\
\hline & \multicolumn{4}{|c|}{ Total Body } & \multicolumn{2}{|c|}{ Bone } & \multicolumn{2}{|c|}{ Lung } \\
\hline & Inhalation & Ingestion & Submersion & Ground & Inhalation & Ingestion & Inhalation & Inge \\
\hline $232 \mathrm{U}$ & $4.5 \times 10^{-10}$ & $1.2 \times 10^{-9}$ & $2.8 \times 10^{-13}$ & $4.2 \times 10^{-6}$ & $6.5 \times 10^{-9}$ & $1.8 \times 10^{-8}$ & $1.4 \times 10^{-8}$ & $1.2 \times 10^{-9}$ \\
\hline${ }^{233} \mathrm{U}$ & $1.2 \times 10^{-10}$ & $3.4 \times 10^{-10}$ & $1.9 \times 10^{-16}$ & $2.3 \times 10^{-8}$ & $2.1 \times 10^{-9}$ & $5.7 \times 10^{-9}$ & $5.2 \times 10^{-9}$ & $3.4 \times 10^{-10}$ \\
\hline${ }^{234} \mathrm{U}$ & $3.9 \times 10^{-11}$ & $1.0 \times 10^{-10}$ & $5.4 \times 10^{-17}$ & $1.0 \times 10^{-8}$ & $6.2 \times 10^{-10}$ & $1.7 \times 10^{-9}$ & $1.6 \times 10^{-9}$ & $1.0 \times 10^{-10}$ \\
\hline $235 \mathrm{U}$ & $7.2 \times 10^{-15}$ & $1.8 \times 10^{-14}$ & $1.2 \times 10^{-18}$ & $4.7 \times 10^{-11}$ & $1.1 \times 10^{-13}$ & $3.0 \times 10^{-13}$ & $2.8 \times 10^{-13}$ & $1.8 \times 10^{-14}$ \\
\hline${ }^{236} \mathrm{U}$ & $3.4 \times 10^{-13}$ & $9.5 \times 10^{-13}$ & $4.4 \times 10^{-19}$ & $9.2 \times 10^{-11}$ & $5.6 \times 10^{-12}$ & $1.5 \times 10^{-11}$ & $1.4 \times 10^{-11}$ & $9.5 \times 10^{-13}$ \\
\hline${ }^{238} \mathrm{U}$ & $3.2 \times 10^{-16}$ & $8.6 \times 10^{-16}$ & $3.0 \times 10^{-21}$ & $1.6 \times 10^{-13}$ & $5.4 \times 10^{-15}$ & $1.4 \times 10^{-14}$ & $1.3 \times 10^{-24}$ & $8.6 \times 10^{-16}$ \\
\hline Th & $6.1 \times 10^{-11}$ & $1.3 \times 10^{-12}$ & $6.5 \times 10^{-15}$ & $9.8 \times 10^{-8}$ & $1.8 \times 10^{-9}$ & $3.8 \times 10^{-11}$ & $3.3 \times 10^{-10}$ & $1.3 \times 10^{-12}$ \\
\hline $232 \mathrm{Th}$ & $5.4 \times 10^{-12}$ & $1.2 \times 10^{-13}$ & $4.2 \times 10^{-20}$ & $8.8 \times 10^{-12}$ & $1.7 \times 10^{-10}$ & $3.8 \times 10^{-12}$ & $1.5 \times 10^{-12}$ & $1.2 \times 10^{-13}$ \\
\hline TOTAL & $6.8 \times 10^{-10}$ & $1.6 \times 10^{-9}$ & $2.9 \times 10^{-13}$ & $4.3 \times 10^{-5}$ & $1.1 \times 10^{-8}$ & $2.5 \times 10^{-8}$ & $2.1 \times 10^{-8}$ & $1.6 \times 10^{-9}$ \\
\hline
\end{tabular}

anternal doses are integrated from plant shutdown to 100 years later.

$\mathrm{b}_{\mathrm{A}}$ resuspension factor of $10^{-9}$ /meter was used to estimate the long-term availability of resuspended particulates for exposure via inhalation, ingestion, and submersion, as given in USAEC Report WASH-1535, "Draft Environmental Statement, Liquid Metal Fast Breeder Reactor Program, Vol. II, Environmental Impact of the LMFBR," March 1974. 
2. Discharges of Hiquids

Aariety of systems for the safe handing of liquid wastes are incorporated in the TORF, in which facility the proposed HTGR Fuel Refabrication Pilot Plant will be installed. These include systems for handing stor drainage. sanitary wastes, and both normally nonradioactive and radioactive process astes. 7 storm drain and sanitary effluents are treated and discharged to melton Branch. The sanitary waste treatment plant is of adequate capacity and provides secondary treatment of the sanitary wastes. Consequent1y. discharges at white oak Dam are expected to be in compliance ith applicable rennessee water quality standards. Storm drain and non-contaminated process streaus will be affected si milarly by dilution with the water of white oak lake, rendering the in compliance with applicable Tennessee standards at the point of discharge (Hhite Oak Daw) to the Clinch River. Radioactive process wastes are separated from the nonradioactive wastes so that almost all of the radionuclides can be removed by the ORNL radwaste treatment system.

(a) Radioactive Emissions. The radioactive process waste liquids will amount to $32 \overline{2}$ liters for each day of operation (approximatel 83.700 iters per year). and these waste liquids will have the composition and quantities given in Table 8. All kn own radioactive vastes are pumped directly in a high-integrity stainless steel piping network to the ORMI. Intermediate-Level waste collection and Treatment sustem. In this system, the liquids are ade basic and piped into a 600-gallon-per-hour waste evaporator. Experience ith this evaporator. Which has been in operation since 1965, indicates that an average decontamination factor of approximately 105 can be attained for the mixture of cadionuclides given in Table 8.

Process wastes susceptible to slight radioactive contamination will be mitored continuously for radioactivity. The initial collection will be in a $500,000-g a 110 n$ settling basin. If it is found that the process wastes contain radioactivity. they will be pumped to the ORNL 10w-level waste system.

The treated effluents from the lom-level siste are released to white oak creek. The estimated average annual concentration of radionuclides at hite Dak Dall that will originate from operation of the proposed pilot plant are given in Table 8. These concentrations were calculated by using the total annul activity of each radionuclide released in the process waste divided by a total decontamination factor of $5 \times 10^{5}$ and the hite oak creek dilution of $1 \times 10^{3}$ ilyear. Thus. the estilates in Table 8 are conservative because they ignore radioactivity loss through ion exchange in the setting basin. radioactive decay, and an average dilution of 350 by clinch River water. When compared ith the population cGs for 
Table 8. Average Annual Quantities of Radionuclides in Liquids to Originate from Operation of the Proposed HTGR Fuel Refabrication Pilot Plant and Resulting Concentrations at White Oak Dam After Treatment and Dilution

\begin{tabular}{|c|c|c|c|c|}
\hline $\begin{array}{l}\text { Radio- } \\
\text { nuclide }\end{array}$ & $\begin{array}{l}\text { Release to } \\
\text { Treatment } \\
\text { Systema } \\
\text { (Ci/year) }\end{array}$ & $\begin{array}{l}\text { Concentration } \\
\text { at White } \\
\text { Oak Dam } \\
(\mu \mathrm{Ci} / \mathrm{m} 1)\end{array}$ & $\begin{array}{c}\mathrm{CG}^{\mathrm{b}} \\
(\mu \mathrm{Ci} / \mathrm{m} 1)\end{array}$ & $\begin{array}{l}\text { Ratio } \\
\frac{\text { WOD }}{C G}\end{array}$ \\
\hline $232 \mathrm{U}$ & $8.5 \times 10^{-1}$ & $1.4 \times 10^{-13}$ & $3 \times 10^{-5}$ & $4.6 \times 10^{-9}$ \\
\hline${ }^{233} \mathrm{U}$ & 1.3 & $2.2 \times 10^{-13}$ & $3 \times 10^{-5}$ & $7.3 \times 10^{-9}$ \\
\hline${ }^{234} \mathrm{U}$ & $4.0 \times 10^{-1}$ & $6.6 \times 10^{-14}$ & $3 \times 10^{-5}$ & $2.2 \times 10^{-9}$ \\
\hline${ }^{235} \mathrm{U}$ & $7.3 \times 10^{-5}$ & $1.2 \times 10^{-17}$ & $3 \times 10^{-5}$ & $3.9 \times 10^{-13}$ \\
\hline${ }^{236} \mathrm{U}$ & $3.7 \times 10^{-12}$ & $6.0 \times 10^{-25}$ & $3 \times 10^{-5}$ & $2.0 \times 10^{-20}$ \\
\hline${ }^{238} \mathrm{U}$ & $4.7 \times 10^{-3}$ & $5.6 \times 10^{-16}$ & $4 \times 10^{-5}$ & $1.4 \times 10^{-11}$ \\
\hline $212 \mathrm{Bi}$ & $2.0 \times 10^{-2}$ & $3.2 \times 10^{-15}$ & $4 \times 10^{-4}$ & $8.0 \times 10^{-12}$ \\
\hline $2^{12} \mathrm{~Pb}$ & $2.0 \times 10^{-2}$ & $3.2 \times 10^{-15}$ & $2 \times 10^{-5}$ & $1.6 \times 10^{-10}$ \\
\hline 212 Po & $1.3 \times 10^{-2}$ & $2.2 \times 10^{-15}$ & $\mathrm{~d}$ & $-\infty$ \\
\hline $216 \mathrm{Po}$ & $2.0 \times 10^{-2}$ & $3.2 \times 10^{-15}$ & $\mathrm{~d}$ & - \\
\hline${ }^{220} \mathrm{Rn}$ & $2.0 \times 10^{-2}$ & $3.2 \times 10^{-15}$ & d & -- \\
\hline $224 \mathrm{Ra}$ & $2.0 \times 10^{-2}$ & $3.2 \times 10^{-15}$ & $2 \times 10^{-6}$ & $1.2 \times 10^{-9}$ \\
\hline${ }^{228} \mathrm{Th}$ & $6.3 \times 10^{-3}$ & $1.0 \times 10^{-15}$ & $7 \times 10^{-6}$ & $1.0 \times 10^{-10}$ \\
\hline${ }^{232} \mathrm{Th}$ & $1.3 \times 10^{-4}$ & $2.2 \times 10^{-17}$ & $2 \times 10^{-6}$ & $1.1 \times 10^{-11}$ \\
\hline $208 \mathrm{TI}$ & $7.3 \times 10^{-2}$ & $1.2 \times 10^{-14}$ & d & - \\
\hline
\end{tabular}

$a_{\text {This }}$ radioactive effluent will also contain traces of Amberlite LA-2, n-paraffin, and 2-ethy1-1-hexanol.

${ }^{b}$ Concentration Guide (CG) for water as stipulated in $10 \mathrm{CFR} 20$, Appendix B, Table II.

${ }^{c}$ (Concentration at White Oak Dam)/(CG).

$\mathrm{d}_{\text {No }} \mathrm{CG}$ 1isted in $10 \mathrm{CFR} 20$ for this short-1ived radionuclide.

continuous exposure, the estimated water concentrations are at least one hundred million times smaller. No significant environirental effects from this inuscule discharge are anticipated.

(bL Chemical Erissions. Nonradioactive process wastes are piped to retention basins adjacent to the HFIR. These are monitored for possible radioactive conta ination and are subsequently discharged to the felton Branch drainage area (non-contaminated) or to the ORNI waste collection and 
Treatment syste (in the event of accidental radioactive contamination). Routine process wastes will consist of approximately 1 iter per day of 0.88 molar sodium nitrate containing a trace of Aberlite LA-2. Discharge of this amount of waste material is not expected to result in serious detrimental effects on aquatic organisms. There are no existing data which would perit routine evaluation of long-term chronic effects on the organisms inhabiting melton Branch and subsequent receiving vaters. A conservative evaluation of the potential for short-term effects can be approached by assuming a daily discharge of 1 liter per day of nitrate astes to be diluted by the historical minimu flom in Melton Branch $(0.1$ cfs). 10 The result culd be a steady-state concentration of sodium nitrate in water equivalent to 0.3 mg/1iter. This calculated concentration is a factor of 25 lover than concentrations shown to elicit ortality 17.5 g/liter) in Gambusia affinis affinis (mosquitofish). an organism ith particularly low tolerance for sodium nitrate.27 The considerable latitude determined by using this conservative approach for the short-term effects suggests a very low potential for any chronic long-teri detrimental effects.

\section{3._Solid_waste_pisposa 1}

All solid cheical wastes resulting from operation of the proposed HTGR Fuel Refabrication pilot Plant will be contaminated with radioactivity. They wil therefore be handled as radioactive wastes. The average annual quantities of radionuclides expected to be present in the solid wastes are given in Table $\mathbf{A} .3$ in Appendix A. These radionuclides ill be contaminants on the solid chemical wastes listed in Table $\mathbf{A} 2$ in Appendix $A$.

The solid waste contaminated with alpha enitters greater than 10 microcuries/kg will be packaged as required for temporary storage or for retention at a national repository. No releases to the environment are expected to result from these methods of solld waste storage.

\section{Land Use and Construction Impact}

There 111 be no change in land use from the current situation. The TORF, hich occupies approximately 0.5 acre in a complex containing the High Flux Isotope Reactor and the Transuranium Processing plant, 111 be internally a dapted to accomodate the ney racility.

The jor construction impacts of land clearing.

excavation, spoil removal, and loss of wildife habitat occurred wen the TURF facility as constructed (1965-1968). with the exception of a sma 11 cooling tover for process vater. no new outdoor construction is planned. This cooling tover 
wil be placed near the Turf on a lawn area near the building. Both drI and wet cooling towers wil be evaluated for this use. If a vet cooling tower is used the blowdown will be subjected to lime-soda treatment to remove phosphates. The chromate 111 be recycled back to the cooling tower. with no release to the enironment.

Anall lay-out yard for the materials to be used in adapting the TuRF for fuel refabrication ill probably be required. Existing law or concrete pad areas can be used for the lay-out yard, and upon completion of construction this area can be restored propt 1 to its present condition.

\section{5.-Pran sportation}

To estimate the impact resulting from the transportation of fuel and refabricated ruel elements to and from the proposed HTGR Fuel Refabrication pilot plant the factors considered were (1) damage to highways and associated structures, (2) increased probability of transportation (non-radiological) accidents. (3) radiation effects on the environment in general, and (4) human radiation injury. The HTGR shipping cask veighs about 2.3 tons. Consequent11. the potential damage to a coad or bridge resulting from the transport of this cask as considered. Highway weight cestrictions limit the routine-shipment gross weight of loaded casks to about 25 cons, although shipments up to 35 tons ay be allowed by special perit from the states Involved. Each shipment must meet state restrictions for protection of coadbeds and bridges, and no damage to roads or bridges is anticipated.

If the point of delivery is assumed to be Idaho, about 70 round trips 111 be required to transport the refabricated fuel elements generated during operation of the proposed pilot plant From Oak Ridqe to Idaho. Transportation of these elements 111 have little or no effect on normal traffic flow. The conventional risks of injury or death due to highway accidents vere also analyzed. For 70 shipments over a distance of about 4600 round-trip iles each, the accident rate would be about 0.55 accident, based on DoT statistics for an average truck accident rate of about 1.7 per willian truck iles for a.l1 hazardous aterial carriers. In 1969 , there vere about 0.51 injuries and 0.039 deaths per accident. At that rate the probability of an accident involving an injury is about 0.28 or one chance in about three. The probability of a death is about one-thicteenth that of an injury fron any type of highway accident (not necessarily nuclear related). The details of the shipping cask in which the cefabricated fuel elewents 111 be transported and the associated quality assurance progra were described in subsection II.B.6. It is not expected that the shipping cask wil permit the release of appreciable quantities of radioactivit to the environment, even under accident 
conditions. The cask as designeds to meet regulations governing containers in hich radioactive waterials are transported (49 CFR 170-189 and 10 CFR 711 , and these regulations cover both nor 1 conditions of transport and hypothetical accident conditions. Mong the requirements ith Which the HTG shipping cask compliess are those which require the cask to be designed and constructed to ith stand free falls through distance of 30 ft onto flat and essentially unyielding surface and through a distance of 40 in. onto a cylindrical punch ithout loss of contents, exposure to temperatures of 1475 degrees for 30 inutes and im inersion in ater to depth of at least 3 ft for 24 hours. No radiation effects to the en ironment or to personnel are expected to result froi the shipment of refabricated fuel elements because the shipping cask in thich they 11 be transpocted as designed specifically for highly irradiated Fuel and the leve 1 of radioactivity invived wil be low. The total contained radioactivity ithin the HTGR shipping cask during any one shipment based on three fuel elements per shipment will be about 10 curies. The potential radiation effects on the en ironment of shipients of reactor fuel have been investigated and reported in UsA EC Report TASH-1238.2 When the methodology described in that report is used individuals residing ithin $100 \mathrm{ft}$ of the center ine of the truck route ould be expected to ceceive radiation doses of about $6 \times 10^{-}$mren frow each shipment of nuclear fuel or an annual dose of about 0.02 mem when 70 shipuents over a 2-year period are assuled. The population dose from such traffic tas estivated to be about $1.8 \times 10^{-7}$ man-rem/mi for unirradited fuel. This corresponds to population doses of less than 0.025 an-ren/pear for the proposed shipment of cefabricated fuel elements.

During 25 years of cadioactive aterial transers there have been no known cases of radiation injury to personnel during transportation of nuclear material. Results of a 1969 survey of radiation exposures during transportation indicate that the annul exposure to drivers and frelght handiers who routinely handle shipments of radioactive materials is well below established radiation orotection guides.

6. Noise

Noise resulting frow operation of the proposed HIGR ruel Refabrication pilot plant should be li ited primarily to that resulting from the shipment of refaricated fuel elements. abou 70 round trips from oak Ridge to a point of delivery assumed to be Idaho 111 be required to transport the refabricated ruel elements generated during operation of the pilot plant. This trafic is estimated to result in infrequent noise of short duration, and although such noise could be objectionable to some persons, it ould not represent an appreciable increase in elther motor freight traffic or 
ambient noise levels in the indiate area. While there are no county or state regulations applicable to motor vehicles. workers ithin the confines of oRN would be protected by the provisions of the occupational safety and Health Act of 1970. The actual processing operations of the fuel refabrication facilit are relatively quiet, with no significant disturbances of either operating personnel or the surrounding area expected. Typlcal noise levels in the imediate area of the proposed project are estimated to be below 75 decibels, weasured over the entire frequency range. Virtually all of the processing 111 be performed behind the 5.5-ft-thick concrete alls of the TURF cells (subsection II. A. 1). These processing noises are not expected to be audible off of the site.

\section{Proiect_Decom missioning}

The amount of liquid radioactive effluent that will be generated bl decomissioning is estinated to be 3000 liters or about 1000 gallons lless than 1 curie per liter, average energy 0.5 MeV. This effluent will be stored in the existing TURF waste tanks for subsequent transfer to the ORNI liquid radioactive waste reatment and storage syster.

The rolume of solid radioactive vaste (shoe covers. rubber gloves, swabs, ops. rags, etc.l that will be generated is estimated to be 14 ar about $500 \mathrm{ft}^{3}$, uncompacted. This waste will be packaged for storage and retrieval at the existing oRNL burial ground. Contaminated equipaent will be decontaminated and packaged for long-ter storage and retrieval at the oR wl burial ground.

Decomissioning of the project 111 have no adverse effect on the environment, and no increase in the size of the existing waste treatment and storage facilities will be required to handle the products of decomissioning.

\section{B. Accidents}

The accidents postulated for the proposed project have a very lom proability of occurrence and are therefore separated from any consideration of probable environmental impact. The safety analysis for the TUR was used in assessing the effects of maxim credible accidents, but it should be recognized that that analysis was based on possible accident conditions during fuel reprocessing operations in wich large quantities of fission products vold be present. Because of the absence of fission products during the fuel refabrication operations described in this report, the estimates of radiation exposure resulting from possible accidents in the proposed pilot plant are far lover than those reported in the TrRP safety and IIs. The facility. syste and process 
designs are such that should an accident occur. 1ittle or no effect would reach the environment. In the event that external aste handing systes were damaged, the pilot plant would be shut down and isolated from these systems to prevent the uncontrolled release of effiuents to the environment. These accidents and their possible environmenta 1 effects are discussed in detail in the following subsections.

1. Fire

The probability of a fire in the HTGR Fuel Refabrication Pilot plant ill be low since the quantity of conbustible material $i 11$ be kept to a mini that is consistent ith process and building requirements. Hovever, there is still the possibility of fire in the pilot plant because organic oils and solvents paper, and combustible gases are used in fuel refabrication. The TURF fire protection systems ill provide complete coverage to all parts of the pilot plant. The interior of the cell bank ill be protected by a high-pressure, gaseous carbon dioxide systen, and regions outside the cells will be protected by a conventional sprinkler system.

In the TuRP safety analysis, the maximul credible accident resulting from a fire could release radioactivity to a cel1. If such an accident should occur, the maximu personnel dose downind would be less than 200 men to the total body. 3 rew to bone, and 7 ren to the 1 ung. No isolation of land area outside of the controlled access area would be required. The affected area would be less than that of the proposed site. The results of an independent analysis of the potential for radioactivity release following a fire were in general concurrence with the estimates previously made. In all but the most extreme conditions of structure damage and adverse meteorological conditions. personnel doses should be less than 200 rem.

\section{Explosions}

The credible types of cherical explosions in the HTGR Fuel Refabrication Pilot Plant would in of Ixtures of hydrogen, organic gases or vapors or

pyrophoric dust ith air. Explosive mixtures that would comprise a significant fraction of the olume of a processing cell in the pilot plant are not credible because of the favorable balance beteen the cate of cell exhaust and the rate of formation of explosive aterial.

The control measures to be used to limit the probability of 1imited-volume explosions include procedures to minimize the occurrence of explosive ixtures and sources of ignition. vessels which liberate radiolytic hydrogen and organic vapors wil be purged with air to maintain lower-than-explosive 
concentrations. Fuel refabrication processes that enploy hydrogen. combustible gases and organic vapors will be monitored and wenever practicable. pre-diluted wth inert gases to assure nonexplosive concentrations. Special operating procedures will be used to minimize the possibility of accumulation of potentially explosive mixtures of pyrophoric dust.

Process operations 111 be limited to those which cannot result in credible types of limited-volume explosions that would exceed the design capabilities of the TuR processing cells. The instantaneous gas generation accompanying the maximu credible explosion in TUR could result in an increase of the gas pressure in a processing cell to a axinum of about 4 in. of ater (gage). The pressure Till return to below atmospheric in less than 1 second. The escape of aerosol through the air intakes wil be negligible because of the backfiow preventers on the intakes. The intake filters would not be ruptured. The integrity of all components of the containment membrane will be aintained under these accident conditions.

In the TURP safety analysis, 7 the maximum credible accident resulting from a cherical explosion considered was one in wich an aerosol of irradiated fuel element dissolver solution as dispersed in the cell air. The outlet filters 111 ithstand any shock wave or overpressure generated by the postulated chemical explosion because they ere designed to withstand greater pressure than the intake filters and the ful1 effects of a shock wave cannot reach them. If some factor other than the explosion resulted in filter failure during an explosion, the maxiul population dose downind vold be less than 1 mren.

In the ITGR Fuel Refabrication Pilot plant, uranium-233 which has been separated from the najority of the fission products 11 be used. Therefore, the environimtal effect of a chemical explosion with the purified uranium-233 should be less than that in the case considered in the ron safety analysis. Therefore, no adverse environmental effects are expected to result from a chemical explosion in the HTGR Puel Refabrication pilot plant.

\section{3.- Criticality}

The probability of a criticality accident in the HTGR Fuel Refabrication pilot plant ill be mantained at a 10\% level by strict adinistrative control and by other safety measures, such as ass linitation of hazardous material. However, if such an accident should occur, gaseous fission products and an aerosol of nonvolatile fission products could be dispersed within the shielded hot cells, and a sall portion of the materials could be released through the filtered ventilation. The high-efficiency particulate air filters are located at a sufficient distance from the 
processing cells that they would not be affected by a criticality incident.

In order to assess the environmental effects of a criticality accident in the proposed HTGR Puel Refabrication Pilot plant, a criticality incident involving $10^{19}$ fissions was hypothesized. It as assumed that the critical mass occurred in either a solution or in a water moderated bed of microspheres. In either case. it is expected that the heat released would boil the water, the critical mass would be dispersed, and the chain reaction would cease. It was assumed that all noble gases and halogens (or halides) would be discharged fro the plant stack 15 minutes after the incident. A decontamination factor of $10^{7}$ as used to determine the fractional release of all other fission products. For these calculations, it was also assumed that the accident occurred during stability conditions with a mind speed of 4.4 meters/second in the northeast direction.

A person standing at the effective perimeter boundary could receive a prompt neutron plus secondary gamma dose of 0.0036 rem. Submersion in the radioactive cloud would result in an aditional dose from external radiation 10.015 mrem and an internal dose comitment (dose integration period of 50 years) from inhalation of the radioactive gases and particulates $(0.00028$ mem to the whole body. 0.00029 rem to bone. 0.098 mren to thyroid, and 0.0022 rem to lung). If person remained at the effective perimeter boundary continuously, he could receive 0.011 mrem the first year and proportionately less each following year as the radionuclides decayed and entered the soil profile.

The maximu individual doses for all pathways of exposure except prompt neutrons and secondary gamas would occur 3000 meters from the TUR. The external dose from submersion would be 0.45 mrems. A person residing continuously at this location would receive an external dose of 0.39 mrem from the first year of exposure following the postulated accident and proportionately less each following year as the radionuclides decayed and entered the soil profile. Inhalation yould result in the largest dose: 0.0099 mrem to the whole body, $0.011 \mathrm{mrem}$ to bone, 3.2 re to thyroid (iodine radionuclides), and 0.082 mrem to the lung.

\section{Natura 1 Disturbances}

Consideration was given to the release of radioactivity from the proposed HTGR Fuel Refabrication pilot plant as a result of possible da me to the TuRF from natural disturbances. The disturbances considered included (a) earthquakes. (b) flooding, (c) high winds, and (d) tornados. 
(a) Earthquakes. The TURF site is located within a zone of low earthquake activity. as illustrated in Fig. 16

(subsection II.D.4). and the probability for significant earthquake damage to the TuRF has been estimated to be low (Appendix B). The epicenters of damaging earthquakes of intensity VII or larger have never been recorded in the area surcounding the TURF site. Prom the seismic risk map (Fig. 16). Which is based on known distributions of damaging earthquakes and corresponding intensities, no shockwaves from distant earthquakes that ight reach the TUR site are expected to be of sufficient frequency or amplitude to inpart physical da

The site is located in seisic risk zone 2 , wich has a corresponding potential for a maximu ground acceleration of from 0.03 to $0.09 \mathrm{~g}$. The areas in the TuRF that vill contain large amounts of special nuclear material will be surrounded b) thick concrete walls (subsection II.A.1). In addition, the relatively short operating life of the pilot plant vill decrease the probability of damaing earthquake activity in the site area. No structural or equipment damage which ould result in appreciable release of radioactive materials as a result of an earthquake is expected.

Lbl-Elooding. The possibility of extensive flooding of the proposed project site is considered to be extremely remote since the TuRF is located on a knoll well above the valley floor and therefore above any possible flood plain. The natural grade of the surrounding area should provide adequate drainage to accomodate any maxinu postulated rainfall intensity. Flooding is therefore not anticipated to result in damage to the proposed facility that would allow the release of radioactivity to the environment.

(c) High Hinds. The specifications to which the TuRF was built included the reguirement that it withstand wind speeds of at least 90 miles per hour. As the arimum ind speed recorded in the area during the last 20 years as 59 iles per hour, the possibility of high winds having an adverse effect on building integrity is considered to be remote.

(d) Tornados. The project site seems protected by the Apalachian and Cuberland hountain Ridges. Two small tornados have been identified in the vicinity of oak Ridge within the past 20 years. The probability of damage to the TUR from tornado activity is therefore considered to be very sma11. In addition the areas in the TuRF that will contain large amounts of special nuclear material wil be surrounded by thick concrete walls (Subsection II.A.1). The cell structures of the ToRF were designed to withstand an internal shock wave of 970 psf ithout failure, and this would make such areas ithstand damage from tornado activit. 
cell which is a glored-box aintenance cell, is not designed to ithstand a tornado. However, this cell wil contain only equipment which has been cleaned previously. and any residual surface contanination is not expected to be released to the environ ant in the event of a tornado.

\section{Hendling Accidents}

handing accident could occur during transfer of uranyl nitrate solution from tank storage in Building 3019 to tank storage in the TuRF. However the transfer process described in subsection II.B.3 is designed to minimize the probability of such an accident. Loading and uloading operations are performed in contained areas, and the operating procedures outlined on detailed checklists are enforced.

An accident involving overturn of the loaded trailer could possibly result in cracks in the solution carrier containment, permitting leakage of the carrier contents. There are on-site administrative controls and onitoring procedures that are intended to permit detection and confinement of any leakage under such conditions. cleanup and decontamination of the local area would be required under such conditions.

possible accidents during the transfer of completed fuel elements. described in subsection II. B.6. consist of the accidental dropping of a fuel element. Depending upon the stage of the process. the conseguences of aropping a fuel element could be the possible fracture of an elewent and the release of radioactivity into the processing ce11, into the crane bay area, or into the shipping cask. No radioactivity would be released from the TURF to the atmosphere under these conditions.

The shipping cask in wich completed fuel elements 111 be transported from the pilot plant to a reactor complies with the regulations for normal conditions of transport as well as those governing the hypothetical accident set forth by the USAE. ${ }^{5}$ Therefore, no release of radioactivity is expected as a result of a possible accident during shipment of completed fuel elements from the pilot plant.

A handing accident associated with project decomissioning could consist of the dropping of either a storage can or a transfer cask in the cell area or a truck accident enroute to a solid waste repository 1 to 2 miles avay from the TURF. only the truck accident could result in any release to the environment, but there yould be no airborne or transferrable radioacti vity because of the decontarination procedures followed prior to loading of the material in the transfer cask. 
6. Response to Accidenta1 Release of Radioactiyity

The ORNI fire department and erergency squad pould respond im im iate 1 to to any accident at the proposed HTGR Fuel Refabrication pilot plant. Accidental release of radioactivit would be detected by the network of alpha, beta-garma, and neutron detectors in the TURF and on the ORNL site. This system is described in tpendix $C$. If a release of radioactivity were large enough to pose the potential for exposure of the public to harmful amounts of radioactivity. state and local authorities would be notified. Contigency plans to provide this response are a part of the operating procedures at oRNI. Areas affected by an such release ould be isolated until surveyed by health physics personnel and decontaminated as required.

IV. UNAVOTDABL EDVERSE ENVIRONMENTAL BPTECTS

Construction and operation of the proposed HTGR Fuel Refabrication pilot plant will result in no known significant adverse environmental impacts which cannot be avoided. The unaroidable releases will cause a maximu potential individual exposure of $3.6 \times 10^{-3}$ mem per year from gaseous effluents (compared with 100 mren/year background) and 100 millionths of the concentration guide from liquid effluents. The chemical emissions in the 1 iguid releases will amount to $1 / 25$ of the concentration known to be lethal to sensitive organisms in the affected waters. However, these unaroidable releases are not expected to have any detectable effect on the environment.

\section{ALTERNAT IVES}

1ternatives to the proposed HTGR Fuel Refabrication Pilot plant fall generally into four categories. They are (1) the alternative of no recycling of HTGR fuel, in which case the pilot plant ould not be built at all and spent fuel would be stored indefinitely; (2) an alternate schedule for building the pilot plant, which would certainl wean a delay because advancenent of the present schedule is impossible: (3) alternatives to the flow sheet for fuel refabrication to be accoplished in the pilot plant because of changes in the design of recycle fuel or the development of better processes or both: and (4) an alternative location for the proposed pilot plant or for storage of completed fuel elements. 


\section{A. No Recycle}

The alternative of no recycle of HTGR fuel was discussed briefly in Subsection II.C.J (a) of this statement. In that subsection it as pointed out that failure to utilize bred fuel wonld increase the undiscounted fuel cycle cost by $\$ 3.4$ to $\$ 19.5$ billion. depending on the size of the HTGR economy. This amount is equivalent to an increase in the unit cost of power from HTGRs of about 0.45 mill/kwh on a levelized basis. According to the data given in Table 2 of subsection II.C.3(a). this represents a 40 to $47 \%$ increase in the fuel cycle cost, again depending on the size of the HTGR economy. and it akes the HTGR less competitive with other sources of electrical power. In adition, the uranium ore and separative work requirements for each HTGR are increased by approximately 54\% over those required by opti al recycle timing.

To estimate the overall environmental inpact of this alternative, one must perform an extensive analysis. containing numerous simplifying assumptions, of the influence in the marketplace of the higher $R T G R$ fuel cycle costs which result from not recycling bred fuel. It ould possibly mean that fever HTGRs would be built. while more coal-fired generating plants and more light-water-cooled reactor plants would be built.

\section{B. Delay in Recrcle}

Delaying the recycling of bred fuel would increase fuel cycle costs and would therefore influence the environmental. situation in a maner similar to that of no recycle. A study has been recently completed at ORN to provide an understanding of the econolics involved in the timing of the HTGR Fuel Recycle Development progran. A computer program was developed to "construct" a fuel cycle industry required to support a given HTGR econom and then compute the cost of operating this industry on the basis of available estimates of the costs of fuel cycle components. BY using this computer program, the influence of constraints, such as the timing of initial comercial recycling of HTGR fuel, can be studied.

For the HTGR construction and operation schedules discussed in subsection II.C.3(a). the lowest fuel cycle costs calculated occur then initial comercial recycling is to be begun in 1984 for the 20- and 41-reactor econories, in 1985 for the 124-reactor economy, and in 1986 for the 85-reactor economy. The penalties calculated for delaying the schedule for recycling spent HTGR fuel are illustrated in Fig. 13 (subsection II.C.2). The calculated dollar values of the penalties have been present worthed to January 1978 by using a $10 \%$ discount factor. Undiscounted penalties would, of course. be uch higher. The penalties represented both in 
present-worthed dollars and in percentages of the fuel cycle costs under optimal recycle timing are given in Table 9.

Table 9. Penalties Associated With Delay in Commercial Reprocessing of Spent HTGR Fuel

\begin{tabular}{|c|c|c|c|c|c|c|c|c|}
\hline \multirow{3}{*}{$\begin{array}{c}\text { Commercial } \\
\text { Reprocessing } \\
\text { Delayed } \\
\text { Unti1 }\end{array}$} & \multicolumn{8}{|c|}{ Pena1ty ${ }^{a}$ for HTGR Economy of } \\
\hline & \multicolumn{2}{|c|}{20 Reactors } & \multicolumn{2}{|c|}{41 Reactors } & \multicolumn{2}{|c|}{85 Reactors } & \multicolumn{2}{|c|}{124 Reactors } \\
\hline & $\left(\$ 10^{6}\right)$ & $(\%)$ & $\left(\$ 10^{6}\right)$ & $(\%)$ & $\left(\$ 10^{6}\right)$ & $(\%)$ & $\left(\$ 10^{6}\right)$ & $(\%)$ \\
\hline 1984 & 0 & 0 & 0 & 0 & 14.2 & 0.19 & 8.0 & 0.07 \\
\hline 1985 & 25.4 & 0.92 & 3.2 & 0.06 & 1.1 & 0.01 & 0 & 0 \\
\hline 1986 & 68.3 & 2.5 & 66.8 & 1.4 & 0. & 0 & 47.0 & 0.4 \\
\hline 1988 & 184.2 & 6.7 & 277.0 & 5.6 & 93.0 & 1.25 & 503.0 & 3.9 \\
\hline 1990 & 313.0 & 11.3 & 519.0 & 10.5 & 242.0 & 3.25 & 1154.0 & 8.9 \\
\hline
\end{tabular}

${ }^{a}$ Present worthed to January 1978 by using a $10 \%$ discount factor.

It is clear from both Fig. 13 and Table 9 that the penalties for delaying recycle are more severe for greater HTGR market penetration and for a rapid buildup of the number of on-line reactors (for example, compare the 85-reactor economy ith the 124-reactor economyl. From the percentage penalties given in Table 9, it appears that delays of 1 or 2 years are not significant but delays of 5 years or longer yould increase HTGR fuel cycle costs significantly.

\section{Plow Sheet Alternatives}

The alternatives to the fuel refabrication flow sheet for the proposed pilot plant involve the processes of kernel or microsphere preparation and coating and fuel rod fabrication and carbonization. Although alternate processes for fabricating recycle fuel would have different chemical effluents. these effluents would be handled by the waste handling facilities of the pilot plant in such a wanner that the environmental impact would not be significantly different from that for the reference processes.

\section{Hicrosphere_preparation}

The reference icrosphere preparation process is for the preparation of thoriu dioxide-uraniu dioxide fissile particles. These icrospheres are then coated and blended with thorium dioxide fertile particles which are fed into the 
refabrication pilot plant from a separate facility. This blended mixture is then formed into fuel rods.

The blending step could be eliminated by increasing the thorium-to-uraniu ratio in the microspheres so that the fuel rods from the refabrication pilot plant would contain only one type of particle. This would greatly increase the amount of heavy metal passing through the refabrication pilot plant, and that might be economically undesirable.

nother alternative would be to eliminate all thorium from the fissile particles, thereby inimizing the amount of heavy metal passing through the microsphere preparation and coating steps in the pilot plant. An advanced process, the weak acid resin process, appears to be economically attractive for this purpose, but particles prepared in this manner must be proved acceptable through extended irradiation testing before changes are made in the current reference designs.

\section{2.-_licrosphere Coating}

The reference microsphere coating process in the pilot plant calls for the application of a multi-layer coating consisting of a buffer layer followed by a pyrolytic carbon layer, a silicon carbide layer, and another pyrolytic carbon layer. This is called a TRISO coated particle.

An alternative to the TRISO coating process is the BISO coating process, which includes no silicon carbide layer and only one pyrolytic carbon layer. The BISo coating process is considerably cheaper, but it does not have the added coating strength and resistance to fission product diffusion provided by the silicon carbide layer. Should the reference refabrication flow sheet be changed to reflect the use of a BISO coated recycle particle, silicon carbide and Vacl would both be eliminated from the source term.

\section{3.-_Fuel_Rod Pabrication}

The reference fuel rod fabrication process is the slug infection process. Aternative processes are available but the effluents from these processes are identical to those from the reference processes.

4.-Fuel_Bod_Carbon ization

The reference fuel rod carbonization process calls for the fuel rods to be heated in the graphite fuel block. The alternative process calls for carbonization out-of-block in packed alumina. This out-of-block procedure produces about $10 \mathrm{~cm}$ of alumina per rod carbonized. Since the alumina would be contaminated, it would be added to solid waste storage. 
The hydrocarbon production for the reference and alternative processes is about the same.

\section{Iternative Locations}

The ToRr was designed and constructed to provide facilities necessary for the installation and operation of pilot plants such as the one being proposed. There are no other existing facilities available that can provide the need of the proposed pilot plant. To install the proposed HTGR Fuel Refabrication pilot plant in another location would necessitate the construction of a nevecility or ajor modifications to an existing facility. either of which would result in increased impact on the environment, extensive delay to the project, and a large capital investment for the facility itself. n alternate location for installation of the pilot plant therefore is not a viable alternative to the proposed project.

The TORF might provide a feasible location for storage of completed fuel iements as an alternative to shipment of these elements to Idaho for storage. However because these completed fuel elements wil be of the port st. Vrain design. they must eventually be shipped to that reactor in colorado or to Idaho for reprocessing. The environmental consequences of these alternatives uill not be appeciably different.

\section{RELATIONSHIP BETYEE SHORT-TERY USE AND LONG-TERV PRODUCTIVITI}

The HTGR Fuel Refabrication pilot plant 11 be a short-1ived project ith an operating duration of 2 to 3 years. Any consumption of natural resources by the proposed project ill be minimal because of the small scale of the operation and its short time span.

The proposed pilot plant 111 be installed in an existing facility (the TURF) and this installation vill involve the utilization of less than 1 acre of land exterior to the TURF for a small cooling tower for process water on a law area near the building. All of the decomissioning activities will occur within the existing TuRF building.

The construction operation, and decomissioning of the proposed HTGR Puel Refabrication Pilot plant wil therefore have an insignificant effect on the long-ter productivity of the environment. 
VII. STATE, LOCAL, OR REGTONAL CONFLICTS

There are no known conflicts with state, local or regional plans or prograns. The proposed pilot plant will be installed in an existing facility wich is entirely ithin a security fence on the OSAEC Oak Ridge Reservation. The installation will be in accordance ith local planning and zoning ordinances. All wates from the pilot plant will be expelied to existing waste disposal systems, and the incremental amount expelled will be an insignificant addition to the present waste streams. The existing linits on effluents from the waste systems will not be exceeded as a result of the addition of wastes from the pilot plant, and specific approval for waste disposal from the proposed project ill not be required.

Transportation of feed aterial to the proposed pilot plant will occur within the OSABC Reservation boundary loak Ridge National Iaboratoryl, and no public transfortation or roads will be involved. Transportation of the refabricated fuel elements fro the pilot plant 111 be in accordance ith all laws and regulations governing such shipment. The required licenses and certificates for shipment of fuel elements have been obtained.

There are no known archeological sites in the imediate area of the proposed project, and the only historic landmark is the oak Ridge Graphite Reactor, which is located 2 to 3 miles an from the TURF site. No activity associated with the proposed project vill affect the archeology or historic significance of the area.

VIII. IRREVERSIBLE AND IRRETRIEVABLE COMMITMENTS OF RESOURCES

OnI a small amount of resources is involved in the construction and operation of a pilot plant of the scale proposed for this project. Some expenditure of materials and capital for construction, power for operation, and human skill and labor will occur, but all of this will be inor hen compared with the expenditure for existing activities occurring in the area surrounding the proposed project site. The proposed HTGR Fuel Refabrication Pilot plant, wich will be installed in an existing facility, is a recycle pilot plant whose primary input ill be fissionable material that has been produced in and reclaimed from spent fuel which has already been reprocessed. The major resource that will be comitted irreversibly and irretrievably is the thorium in the feed material, and some process chemicals will also be comitted. The total thoriu consumption will be about 4000 $\mathrm{kg}$ over the entire life of the project, and about $90 \%$ of this ill be reclaimable after approximately 15 years. An 
additional resource to be consumed will be an estimated 70,000 to 100.000 gallons of fuel for truck transportation of the refabricated fuel elements from the pilot plant and about $4.4 \times 10^{6} \mathrm{khh} /$ year of electrical energy. Other resources wi11 be virtualiy undisturbed.

Use of the environment through implementation of the proposed project will not represent a significant commitment of resources because of the small scale of the pilot plant. the use of an existing facility, and the minimal release of effluents. In the event of an unanticipated release with the potential for detrimental environmental effects, the existing monitoring programs in the facility and the surrounding area would quickly detect and permit these effects to be remedied.

\section{BENETT-COST ANALYSIS}

The relationships among the economic, societal, and environmental benefits and costs for the proposed project are such that the potential for large benefits can result with essentially no societal and environmental costs. The benefits to be derived from implementation of the proposed project will occur at two levels: (1) advanced technology for fuel

refabrication and (2) the improved fuel cycle economics and resource utilization that ill result from this advancement in technology.

\section{A. Sumary of Benefits}

As discussed in section II.C. the calculated benefit of recycling HTGR fuel is about 0.45 mill/k whr with savings depending on the size of the HTGR economy. In addition to decreasing the cost of electric power, recycling of HTG $R$ fuel will save a considerable portion of uraniu reserves, thereby benefiting power costs for all reactor designs. Fuel recycling provides the additional benefits realized from not having to build and operate large, expensive facilities for storage of spent fuel.

The construction and operation of the proposed HTGR Fuel Refabrication Pilot plant ill provide essential information needed for the construction and operation of full-scale comercial fuel refabrication plants. I mplementation of the proposed project ill allow design changes to be made to processes. remote equipment, and handling procedures at a developmental stage when such changes are relatively inexpensive. Operation of the pilot plant will provide the information necessary to confir the design for processes and equipment, assess equipment reliability and safety standards, and perform economic evaluations for application to full-scale 
conmercial plants. This operation 11 also provide data which ill ake possible a better evaluation of the environiental effects of full-scale fuel recycle programs.

An additional benefit of the proposed project ill be the production of 150 to 200 refabricated HTGR 1 uel elements for eventual use in electric power generating stations.

\section{B. Sun nary of Costs}

The preliminary capital cost estilate for construction of this facility was estimated in 1973 to be $\$ 10$ million and the annual operating cost over the two-year period was projected to be about \$4 milion. The preliminary nature of the 1973 construction cost estiate was discussed in detail in section I. Construction activity associated with the existing facility (the TURF) vill result in no disruption of the local society or ecology.

The environmental ilpact that will result from operation of the proposed HTG Fuel Refabrication pilot plant 111 be the release of a small quantity of effluents. The gaseous celease to the atmosphere will be virtuall undetectable. ranging from $1 \%$ for co down to less than 1 ten illionth of ambient or allowable concentration for other effluents. The discharges of liquids are more significant, but the result in radioactive releases of only one hundred millionth of the allowable maximum permissible concentrations and cherical effluents of less than $1 / 25$ of the knoun lethal concentration for sensitive organisms in the waters affected. The disposal of solid wastes resulting from operation of the proposed pilot plant will not result in releases to the environient and will not require expansion of existing solid vaste disposal areas.

The sum of the environmental costs is therefore not expected to be significant over the entire life of the proposed project.

C. Benefit-Cost Evaluation of Alternatives

of the alternatives evaluated, only the alternatives of not recycling HrG fuel of delaying recycling, and of alternative locations ould result in a significanty different benefit-cost analysis. The no-recycle alternative has effects that would alter the HIG econow to the extent that the en ironental effects of such competing energy sources as fossil-fueled plants and light-water-cooled reactor plants ust be considered. This alternative is discussed in detail in subsection. but it is concluded here that the i molementation of this alternative would result in either a

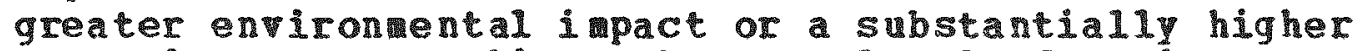
economic cost to achieve the same level of environiental 
impact that ould be afforded by comparable HTG plants. The proposed project vould be affected by implementation of this alternative because the need for the pilot plant is directly associated with the need for recycling of HTGR fuel. The no-recycle alternative was therefore refected.

The alternative of delaying the recycle of HTGR fuel affects the economics of HTGR operation but not as severely as the no-recycle alternative. This alternative is discussed in detail in subsection. . The delayed recycle alternative to the proposed project was judged unacceptable because delayed pilot plant operation vold result in a substantial decrease in the benefits to comercial refabrication plants from the pilot plant increased developmental costs incurred by conmercial plants and a subsequent delay in the ir operation pending pilot plant operation and increased fuel cycle costs during the interim.

process flow sheet alternatives would result in no significant change in the environmental impact of the pilot plant but ight result in slightly increased costs. Developing a new or alternate site would result in increased environmental impact. increased costs, and a delay in pilot plant operation of from 3 to 5 years.

\section{Conclusions}

In assessing and balancing the anticipated benefits against the environmental and economic costs, and after considering the a vallable alternatives and their environmental effects. it is concluded that the proposed HTGR Puel

Refabrication pilot plant project should be inplenented.

\section{SA FEGURD CONSIDERATIONS}

The HTGR Fuel Refabrication pilot plant will be operated within the framework of control procedures for special nuclear aterials applicable to all such operations being performed at oak Ridge National Laboratory. the present time the oRNL inventory of special nuclear aterials includes about $2000 \mathrm{~kg}$ of uranium-233 and $2000 \mathrm{~kg}$ of uraniu-235. The added inventory and throughput from the conduct of the proposed project 111 be but a small fraction of the curcent inventory.

\section{A. Hature and Quantities of Special Huclear Material}

Uraniu- 233 will be recelved fro the HTG fuel reprocessing facility in Idaho in the form of uranl nitrate 
solution or uranium trioxide powder. It will be stored and purified (to rewove the uraniul -232 daughter produrts and associated penetrating gama radiation) in the National storage racility for vraniu-233. After purification the aterial will be delivered as uranl nitrate solution in a 174-1iter shielded container to the HTGR Fuel Refabrication pilot plant. which is to be installed in the existing Thorium-Uranim fuel Cycle Developent Facility (TIRF). The concentration of uraniu 111 be 100 to 200 grams per 1 iter. with less than $1000 \mathrm{ppm}$ of uranium-232.

About $200 \mathrm{~kg}$ of uraniu-233 will be processed to produce 150 to 200 fuel elements during the two-year operating period (from mid-calendar-year 1978 to id-calendar-year 1980 ) of the proposed HTGR Fuel Refabrication pilot plant. Because of the biological hazard from the radiation associated with recycle uranium-233, all fabrication operations, including loading of the fuel rods into the hexagonal fuel elenents, will be performed in a remotell operated hot-cell facility. The fuel rods are graphite "sticks" $1 / 2$ to $5 / 8$ in. in diameter and 2 to 3 in. long. wich contain coated fissile (uranium-233) and fertile (thorium particles, ith about 0.1 to 0.4 gram of uranium-233 per rod. Each loaded fuel element ill contain approximately $0.5 \mathrm{~kg}$ of uranium-233. The elements will be stored in dry storage racks in the processing cell penaing shipment to a reactor or to the HTGR fuel storage facility in Idaho. Scrap fro the refabrication operation (reject coated particles and reject fuel rods) that cannot be recycled in the TURF will be returned to Idaho for reprocessing in the HTGR fuel reprocessing facility.

\section{B. Physical Protection}

Building 3019 (National storage Facility for Uranium-233). where the uranium-233 feed aterial 111 be stored and purified. Is ithin the perimeter fence surrounding the ORNL site. Entrance to the ORNL site is guarded. Within the building. the aterial is stored in locked vaults in the shielded hot-cell facilities. Building 7930 (TURF). where fabrication operations ill occur, is also with in a fenced and guarded area. The shielded carrier used to transfer the inaterial from the storage Facility to the noR pighs approximately 8 tons and is loaded and unloaded by a remotely operated pneumatic system ith continuous ionitoring of flows during transfer operations. as previously indicated, 211 fabrication operations wil be performed remotely in hot cells.

From the standpoint of possible diversion, the nost vulnerable point in the refabrication process ill occur after the urany 1 nitrate feed waterial has been purified from the uranium-232 daughter products and before its introduction into the cemotel operated hot-cell facility in the TuRP. At this 
point, the material could be handed in unshielded facilities. However, the systen used to handle the purified raterial and transfer it to and from the shielded carrier wil be shielded and remotely operated. Diversion of any uranium-233 would require extensive surrepitious modification of the systen or substitution of a transfer cask ith special fittings. To be successful, such surreptitous activities would require an extensive breakdown of the normal security systems and safeguards procedures.

\section{C._- Material Control_and Accountability}

The proposed HTGR Puel Refabrication Pilot plant vill be operated ithin the framework of the control procedures for nuclear materials applicable to all operations involving special nuclear aterial carried out at the oak Ridge National Laboratory. At the present time, the DRNL inventory includes about $2000 \mathrm{~kg}$ of uraniu -233 and $2000 \mathrm{~kg}$ of uranium-235. The control procedures are based on ritten requirements and are subject to the approval of the lanager of the AC Oak Ridge operations office.

In addition to the control procedures applicable to all operations involving special nuclear material specific procedures are being developed for the HTGR fuel refabrication operation. For example special equipent and procedures are being developed for the assay of uranium-233 thorium-232 fuel. Assa problems peculiar to remote HTG fuel refabrication that ill be investigated in tire to meet the pilot plant demonstration program schedule include the development of instruments for cenote operation: the adaptation and modification of assay techniques developed for uranium-235 fuels to the uranium-233 thorium-232 system: and the development and implementation of special techniques for that system, including the use of calorimetry for the assay of feed. in-process, and scrap material.

A special development program as initiated in id-fiscal-year 1974 under the direction of the AEC Division of Nuclear waterials Security now the Division of Safeguards and security). The first phase of this program deals ith the assay of HTGR fuel containing uraniullit-235, and it will be completed in the fall of 1975. here applicable. data from this phase of the progran ill be used for the recycle uraniu-233 fuel fabrication process.

\section{Safeguard Provisions for Materials in Transit}

The recycle fuel elements 11 be shipped in a fuel elewent cask which will veigh from 10 to 23 tons and wil hold two or three elements containing a total of about $1.5 \mathrm{~kg}$ of 
uranium-233. Comercial carriers vill be used to transport the cask in accordance vith AEC transportation safeguards requirements. About 70 round trips fro oak Ridge to the delivery point 111 be needed to transport the 150 to 200 fuel elements to be produced over the two-year operating period.

\section{E.-- Conclusions}

The added inventory and throughput of special nuclear waterial at the ORNI site from conduct of the proposed project ill be a small fraction of the current inventory at oRNL. The safekeeping of the uranium-233 feed materia 1 , fuel fabrication inter mediates, and final products ill not require ajor changes in the existing safeguards program at oRll. The inherent radioactivity of the products requires remote handing procedures which enhance the security of the material by minimizing direct operator contact and deter ring potential diverters.

The physical protection system now in existence at orNu is adequate for the anticipated forms and quantities of HTGR fuel materials. The plans for safeguarding the material. during shipment are adequate, and the security of the material in transit is enhanced by the fabricated form in which the uranium-233 is found, the penetrating radiation present in the fuel, and the massive shipping container used.

Research and development on measurement problems associated with HTGR fuel aterials are being conducted in a timely fashion so that improved measurement techniques wil be available to apply to the pilot plant operation and alidate the for later safeguards application at the full-scale commercial recycle fuel fabrication facility.

\section{REFER ENCES}

1. "Gas-Cooled Reactor and Thoriun utilization Programs. Annual Progress Report period Ending september 30. 1971. USA BC Report ORNL-4760, Oak Ridge National Laboratory. Januar $\$ 1973$.

2. R. W. Horton et al. "Criticality analysis: LWBR Asistance Program in Building 3019," UsAEC Report ORNI-TH-3469. Oak Ridge National Laboratory. March 1972.

3. R. W. Horton et al. Safet Analysis: LBR support Program in Building 3019 pilot plant, "usa BC Report ORN I-T -3567 . March 1972 . 
4. J. R. Parcot and R. E. Brooksbank. "The Handing of Kilogra Quantities of 2330 by Direct and Remote Methods at the oRNL Central Dispensing station, Proceedings of the Fifteenth Conference on Remote systems Technology. American Nuclear society. 1967.

5. Mina1 Design teport for Fort st. Vrain puel shipping Cask ith A-Built Information USAC Report GADR-55, Rev. 1. Gulf General tomic Conpany. San Diego. California. November 5,1971 .

6. Mo er Puels Processing Facility. National Reactor Testing station. Idaho, "ISAC Report WhH-1512, united states tomic Energy Comission. April 1972.

7. J. Anderson. S. E. Bolt. and J. H. Chandler. "Safety Analysis for the thorium-0ranium Recycle Facility USA RC Report ORNL-4278, Oak Ridge National Laboratory. Hay 1969.

8. Nuclear Power 1973-2000, USAEC Report WASH-1139, United States Atomic Energy Comission. Forecasting Branch. December 1. 1972 .

9. Daily, Monthly. a nd Annul Climatological Data for Oak Ridge. Tennessee. January 1951 through Decenber 1971," 0. S. Department of Comerce, National oceanic and tmospheric Adinistration. Air Resources Atmospheric Turbulence and Diffusion Laboratory. Oak Ridge. Tennessee, July 1972.

10. W. Master. Hydrologic Data for the cak Ridge Area. Tennessee" Geological survey ater-Supply paper. $1839-N, 1967$.

11. Clinch River steering comittee "Comprehensive Report of the CIInch River StudY, USABC Report ORNL-4035, Oak Ridge National Laboratory. 1967.

12. M. C. MCCIain and 0 . H. HeYers "Seisill History and Seismicity of the southeastern Region of the united states "USA EC Report ORNL-4582, Oak Ridge National Laboratory. 1970 .

13. J. S. olson. G. Cristofolini, and s. Cristofolini, editors. Mak Ridge. Tennessee. Flora: 1. PrelininarI Aphabetic Inventory of Vascular Plants " OSAEC Report ORNL-TH-1232, Oak Ridge Vational Laboratory. 1966.

14. F. G. Tay1or. Jr. Wak Ridge, Tennessee, Plora: 2. Spring lowering Datas Dniversity of Tennessee Arboretu societs Bulletin, 4: 13-19 (1969). 
15. J. W. Curlin. Morest magement Plan, AC Oak Ridge Reservation." OSAEC Report ORNL-TM-1317, Oak Ridge Nation al Laborator $\$$. 1965.

16. "Threatened MildIife of the United states, "1973 Edition v. S. Department of the Interior, U. S. Government Printing office. Washington, D. C. 1973.

17. S. E. Rolehmainen and D. J. Nelson. Mhe Balances of 37cs. Stable Cesiur and the Feeding Rates of Bluegill (Lepomis macrochicus Raf.) in wite oak take, "ISAEC Report ORNL-4445. Oak Ridge vational Laboratory. 1969.

18. Union Carbide Corporation. Nuclear Division. Mroposal to Designate the AEC Oak Ridge Reservation as an Environmental stud Park" oak Ridge National baboratory unnubered publication. November 1972.

19. K. E. Cowser et al. Evaluation of Radiation Dose to Man from Radionuclides Released to the Clinch River" pp. 639-671 in Proceedings of symposium on Disposal of Radioactive lastes into seas. Oceans and surface Maters. Internationa 1 tomic Energy Agency. vienna, 1966.

20. En ironmental Protection Agency. "National Primary and Secondary hir qulity standards," Federal Register. Vol. 36. No. 84. April 30, 1971.

21. "Standards for Protection Against Radiation "Title 10. Code of Federa 1 Requlations. Part 20, December 1969.

22. Internationa 1 Comission on Radiological protection. Recommendations of the Internationa 1 Connission on Radiological Protection lReport of Comnittee 2 on Permissible Dose for Internal Radiationl. ICRP publication 2, Pergamon Press, London, 1959.

23. W. D. Turner. S. V. Raye, and P. S. Rohwer, "EXRE and INREM, Computer codes for Estimating Radiation Doses to Populations from construction of a sea-level Canal with Nuclear Explosives, "USAEC Report $k-1752$, Union Carbide corporation, vclear Division, Conputing Technology center. Oak Ridge. Tennessee, September 1968.

24. W. D. Turner. "The EXREM II computer code for Estimating External Doses to populations from Construction of a sea-tevel canal ith viclear Explosives, USACC Report CTC-8, Union Carbide Corporation. Nuclear Division. Computing Technology Center, Oak Ridge. Tennessee, JulY 1969.

25. K. Z. Morgan and J. E. Turner editors Principles of Radiation protection. John Wiley and Sons. Inc.. New Tork, 1967 . 
26. G. J. Hine and G. I. Brome11, editors Radiation Dosimetry. Academic Press, New Iork, 1956.

27. J. E. MCKee and H. M. Molf, editors, Mater Quality Criteria," California state Water Resources Control Board Publication $3-1963$.

28. "Environmental Survey of Transportation of Radioactive Materials to and from puclear power plants." OSA EC Report WASH-1238, United States Atomic Energy Comission. Directorate of Regulatory standards. Decenber 1972 . 
APPENDIXES 
-

• 


\section{Appendix A}

SOURCE TERMS FOR WASTES TO BE GENERATED

BY HTGR FUEL REFABRICATION PILOT PLANT OPERATION

Table A.1. Chemical Effluents From Stack Resulting From HTGR Fuel Refabrication Pilot Plant Operation (Based on 25 Kilograms of Heavy Meta1, U + Th, per Day)

\begin{tabular}{|c|c|c|c|}
\hline \multirow[b]{2}{*}{ Species } & \multirow{2}{*}{$\begin{array}{c}\text { Annual } \\
\text { Release } \\
\text { Rate } \\
\text { (tonne/year) }\end{array}$} & \multicolumn{2}{|c|}{ Concentration $\left(\mu \mathrm{g} / \mathrm{m}^{3}\right)$} \\
\hline & & $\begin{array}{l}\text { At Stack } \\
\text { Exit }^{a}\end{array}$ & $\begin{array}{c}\text { At Site } \\
\text { Boundaryb }\end{array}$ \\
\hline $\mathrm{H}_{2}$ & 1.8 & $2.6 \times 10^{3}$ & 0.015 \\
\hline Inert (Ar, He) & 25.0 & $3.6 \times 10^{4}$ & 0.20 \\
\hline $\mathrm{CO}_{2}$ & 53.0 & $7.2 \times 10^{4}$ & 0.40 \\
\hline $\mathrm{CO}$ & 2.7 & $3.6 \times 10^{3}$ & 0.020 \\
\hline $\mathrm{NO}_{\mathrm{x}}$ & 0.124 & 174 & 0.00001 \\
\hline Surfactant & 0.0033 & 4.8 & 0.000029 \\
\hline $\begin{array}{c}\text { 2-ethyl-1- } \\
\text { hexanol }\end{array}$ & 0.0033 & 5.2 & 0.000029 \\
\hline
\end{tabular}


Table A.2. Solid Chemical Effluents Resulting From HTGR Fuel Refabrication Pilot Plant Operation (Based on 25 Kilograms of Heavy Metal per Day)a

\begin{tabular}{|c|c|}
\hline Chemical & $\begin{array}{l}\text { Annual } \\
\text { Release Rate } \\
\text { (tonne/year) }\end{array}$ \\
\hline$A s h^{b}$ & 0.0040 \\
\hline $\mathrm{NaCl}{ }^{\mathrm{C}}$ & 3.3 \\
\hline $\mathrm{SiC}^{\mathrm{c}}$ & 0.21 \\
\hline $\mathrm{NaNO}_{3}$ & 5.2 \\
\hline $\mathrm{NaHCO}_{3}$ & 2.6 \\
\hline $\begin{array}{l}\text { Volume of alpha-contaminated } \\
\text { non-burnable solids (filters, } \\
\text { tools, etc.) }\end{array}$ & $3 \times 10^{3} \mathrm{ft}^{3} / \mathrm{yr}$ \\
\hline \multicolumn{2}{|c|}{$\begin{array}{l}\text { aAll of these solid effluents will be contaminated } \\
\text { with the radionuclides listed in Table A.3 and will be } \\
\text { shipped to a waste management facility. } \\
\mathrm{b}_{\text {The ash will result from burning of waste carbon, }} \\
\text { based on the assumption that the soot and graphite } \\
\text { components from the coating furnace will be burned in } \\
\text { the HTGR Fuel Refabrication Pilot Plant. } \\
\text { c This is based on the assumption that all of the } \\
\text { particles coated in the HTGR Fuel Refabrication Pilot } \\
\text { Plant will be TRISO. If they are BISO, there will be } \\
\text { no NaCl or SiC. }\end{array}$} \\
\hline
\end{tabular}


Table A.3. Radionuclides in Solid Effluents Resulting From HTGR Fuel Reprocessing Pilot Plant Operation (Based on 25 Kilograms of Heavy Metal per Day)

\begin{tabular}{ll}
\hline \multicolumn{1}{c}{ Radionuclides } & $\begin{array}{c}\text { Annual } \\
\text { Release Rate } \\
\text { (Ci/year) }\end{array}$ \\
\hline $232 \mathrm{U}$ & 8.5 \\
$233 \mathrm{U}$ & 13.0 \\
$23{ }^{4} \mathrm{U}$ & 4.0 \\
$23{ }^{5} \mathrm{U}$ & $7.3 \times 10^{-4}$ \\
$236 \mathrm{U}$ & $3.7 \times 10^{-2}$ \\
$238 \mathrm{U}$ & $3.7 \times 10^{-5}$ \\
$212 \mathrm{Bi}$ & 0.20 \\
$212 \mathrm{~Pb}$ & 0.20 \\
$212 \mathrm{Po}$ & 0.13 \\
$216 \mathrm{Po}$ & 0.20 \\
$224 \mathrm{Ra}$ & 0.20 \\
$220 \mathrm{Rn}$ & 0.20 \\
$228 \mathrm{Th}$ & 0.20 \\
$232 \mathrm{Th}$ & $4.0 \times 10^{-3}$ \\
$208 \mathrm{Tl}$ & $7.3 \times 10^{-2}$ \\
\hline
\end{tabular}


Table A.4 Radiological Effluents From Stack Resulting From HTGR Fuel Refabrication Pilot Plant Operation (Based on 25 Kilograms of Heavy Metal per Day)

\begin{tabular}{|c|c|c|c|}
\hline Radionuclide & $\begin{array}{c}\text { Annual } \\
\text { Release Rate } \\
\text { (Ci/year) }\end{array}$ & $\begin{array}{c}\text { Concentration } \\
\text { At Stack } \\
\text { Exit }\end{array}$ & $\begin{array}{l}(\mu \mathrm{Ci} / \mathrm{m} 1) \\
\text { At Site } \\
\text { Boundary }\end{array}$ \\
\hline${ }^{232} \mathrm{U}$ & $1.7 \times 10^{-4}$ & $2.3 \times 10^{-13}$ & $1.3 \times 10^{-18}$ \\
\hline${ }^{23}{ }^{3} \mathrm{U}$ & $2.5 \times 10^{-4}$ & $3.6 \times 10^{-13}$ & $2.0 \times 10^{-18}$ \\
\hline${ }^{234} \mathrm{U}$ & $8.0 \times 10^{-5}$ & $1.1 \times 10^{-13}$ & $6.3 \times 10^{-19}$ \\
\hline${ }^{235} \mathrm{U}$ & $1.5 \times 10^{-8}$ & $2.0 \times 10^{-17}$ & $1.2 \times 10^{-22}$ \\
\hline${ }^{236} \mathrm{U}$ & $7.3 \times 10^{-7}$ & $1.0 \times 10^{-15}$ & $5.6 \times 10^{-21}$ \\
\hline $237 \mathrm{~Np}$ & $2.0 \times 10^{-15}$ & $2.7 \times 10^{-24}$ & $1.6 \times 10^{-29}$ \\
\hline${ }^{238} \mathrm{U}$ & $7.3 \times 10^{-10}$ & $1.0 \times 10^{-18}$ & $5.6 \times 10^{-24}$ \\
\hline${ }^{240} \mathrm{Pu}$ & $4.1 \times 10^{-27}$ & $5.5 \times 10^{-36}$ & $3.3 \times 10^{-41}$ \\
\hline $212 \mathrm{Bi}$ & $4.0 \times 10^{-7}$ & $5.8 \times 10^{-16}$ & $3.3 \times 10^{-21}$ \\
\hline${ }^{234} \mathrm{~Pa}$ & $7.3 \times 10^{-10}$ & $9.8 \times 10^{-19}$ & $5.6 \times 10^{-24}$ \\
\hline $212 \mathrm{~Pb}$ & $4.0 \times 10^{-7}$ & $5.8 \times 10^{-16}$ & $3.3 \times 10^{-21}$ \\
\hline 212 Po & $2.6 \times 10^{-7}$ & $3.7 \times 10^{-16}$ & $2.1 \times 10^{-21}$ \\
\hline $216 \mathrm{Po}$ & $4.0 \times 10^{-5}$ & $5.8 \times 10^{-14}$ & $3.3 \times 10^{-19}$ \\
\hline $228 \mathrm{Ra}$ & $5.6 \times 10^{-8}$ & $7.6 \times 10^{-17}$ & $4.3 \times 10^{-22}$ \\
\hline${ }^{224} \mathrm{Ra}$ & $4.0 \times 10^{-5}$ & $5.8 \times 10^{-14}$ & $3.3 \times 10^{-19}$ \\
\hline $220 \mathrm{Rn}$ & $4.0 \times 10^{-5}$ & $5.8 \times 10^{-14}$ & $3.3 \times 10^{-19}$ \\
\hline $228 \mathrm{Th}$ & $4.0 \times 10^{-6}$ & $5.8 \times 10^{-15}$ & $3.3 \times 10^{-20}$ \\
\hline $231 \mathrm{Th}$ & $1.5 \times 10^{-8}$ & $2.0 \times 10^{-17}$ & $1.2 \times 10^{-23}$ \\
\hline $232 \mathrm{Th}$ & $8.0 \times 10^{-8}$ & $1.1 \times 10^{-16}$ & $6.3 \times 10^{-22}$ \\
\hline $234 \mathrm{Th}$ & $7.3 \times 10^{-10}$ & $9.8 \times 10^{-19}$ & $5.6 \times 10^{-24}$ \\
\hline $208 \mathrm{~T} 1$ & $1.5 \times 10^{-7}$ & $2.1 \times 10^{-16}$ & $1.2 \times 10^{-22}$ \\
\hline
\end{tabular}

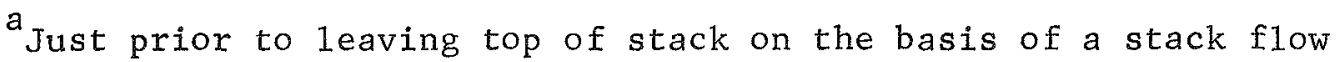
rate of $60,000 \mathrm{scfm}$.

$\mathrm{b}_{\text {Based on }}$ a dispersion factor $(X / Q)$ of $2 \times 10^{-7}$. 
Appendix $B$

\section{CHARACTERIZATION OF EXISTING ENVIRONMENT}

The United States Atomic Energy Comission's oak Ridge Reservation present1y consists of approximately 37,000 acres of 1 and adjacent to the city of oak Ridge in Anderson and Roane Counties. Tennessee. The land is part of an original 92 -square mile tract purchased in 1942 to serve as an atomic development and production center for the U.S. Arm $y$ corps of Engineers Manhattan Project. The Reservation, hich may be visualized as an irregular land mass encompassing the USAEC installations illustrated in ig. 14 (Subsection IT.D). is located 15 iles west of Knoxville. Tennessee, the major population center in the area. The Tennessee valley Authority's Melton Hill and latts Bar Reservoirs on the clinch and Tennessee Rivers, respectively. form eastern, southern. and vestern boundaries of the property and the City of oak Ridge lies along the northern perimeter.

The Reservation is located in the Ridge and valley physiographic province, wich is characterized by parallel ridges of sandstone, shale, and cherty dolomite separated by valleys of less weather resistant limestone and shale. The ridges are oriented southwest-northeast, and elevations range Erom 750 to 800 ft at the valley floor to 1000 to $1200 \mathrm{ft}$ at the ridge crests.

The ecological systems of the Reservation are characteristic of those found in the inter ountain regions of Apalachia from the 1 legheny loutains in southern pennsylvania to the southern extension of the cumberlands in northern Alabama. The area has been under governinental control for the past 30 years and has not been unduly disturbed except for experimental use and regulated forest management.

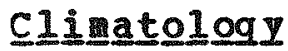

The National oceanographic and trospheric Adinistration (NOAA) has operated a meteorological observation progran at oak Ridge for over 20 years. In addition to recording day-to-day weather data for the plant sites $(X-10, Y-12$, and $\mathrm{K}-25$ ) and Oak Ridge townsite, the NOA staff has aintained a research and development progra to improve the reliability of prediction and measurement of meteorological parameters which influence safe conduct of operations on the oak Ridge Reservation. A onthly climatic sumary for the oak Ridge area based on 20 years of records, is given in Table B. 1. seasonal wind speeds and directions in the oak Ridge area during periods of lapse and inversion conditions are presented in Fig. B. 1 . 
Table B.1. Monthly Climatic Summary for the Oak Ridge Area Based on a 20-Year Recorda

\begin{tabular}{lcccccc}
\hline & \multicolumn{3}{c}{ Temperature $\left({ }^{\circ} F\right)$} & \multicolumn{2}{c}{ Precipitation (in.) } & \multicolumn{2}{c}{$\begin{array}{c}\text { Solar Radiation } \\
\text { Month }\end{array}$} & \cline { 2 - 4 } Mean & Maximum & Minimum & Rain & Snow & month $^{-1}$ ) \\
\hline Jan & 37.9 & 47.0 & 28.8 & 5.3 & 3.4 & 5.6 \\
Feb & 40.9 & 51.2 & 30.6 & 5.3 & 2.6 & 6.7 \\
March & 47.5 & 58.7 & 36.3 & 5.6 & 1.3 & 10.1 \\
Apri1 & 59.0 & 71.1 & 46.9 & 4.4 & 0.01 & 12.3 \\
May & 66.8 & 79.1 & 54.5 & 3.6 & 0 & 15.3 \\
June & 74.0 & 85.2 & 62.7 & 4.0 & 0 & 15.1 \\
Ju1y & 76.9 & 87.3 & 66.4 & 5.6 & 0 & 13.4 \\
Aug & 76.0 & 86.7 & 65.2 & 3.8 & 0 & 13.5 \\
Sept & 70.1 & 81.5 & 58.7 & 3.3 & 0 & 11.3 \\
Oct & 59.3 & 71.3 & 47.2 & 2.7 & 0 & 9.6 \\
Nov & 46.9 & 57.8 & 35.9 & 4.2 & 0.5 & 5.8 \\
Dec & 39.7 & 48.8 & 30.6 & $\underline{5.7}$ & 2.5 & 4.7 \\
Annual & 57.9 & & & 53.5 & 10.3 & 123.4 \\
\hline
\end{tabular}

a"Dai1y, Month1y, and Annual Climatologica1 Data for Oak Ridge, Tennessee, January 1951 through December 1971," Air Resources Atmospheric Turbulence and Diffusion Laboratory, Oak Ridge, Tennessee, Ju1y 1972 .

During the 20-year period of record (1951-1971), the extremes of daily temperature have varied from a low of -9 degrees $F$ in January to $a$ high of 105 degrees $F$ in July.

The average wind speed in the Oak Ridge area is 4.4 miles per hour (mph). The peak gust of record was 59 mph. Calm conditions prevail $10 \%$ of the time. Storm tracks travel northwest to southeast.

The average annual ra infall in the Oak $\mathrm{Ridge}$ area is 53.5 in. Annul snowall averages 10.3 in.. and $95 \%$ of this precipitation occurs between December and March. The average number of thunderstorms per year is 53 , and there are 24 days of heavy fog. clear conditions prevail $30 \%$ of the time: partly cloudy, 25\%: and cloudy, 45\%. 

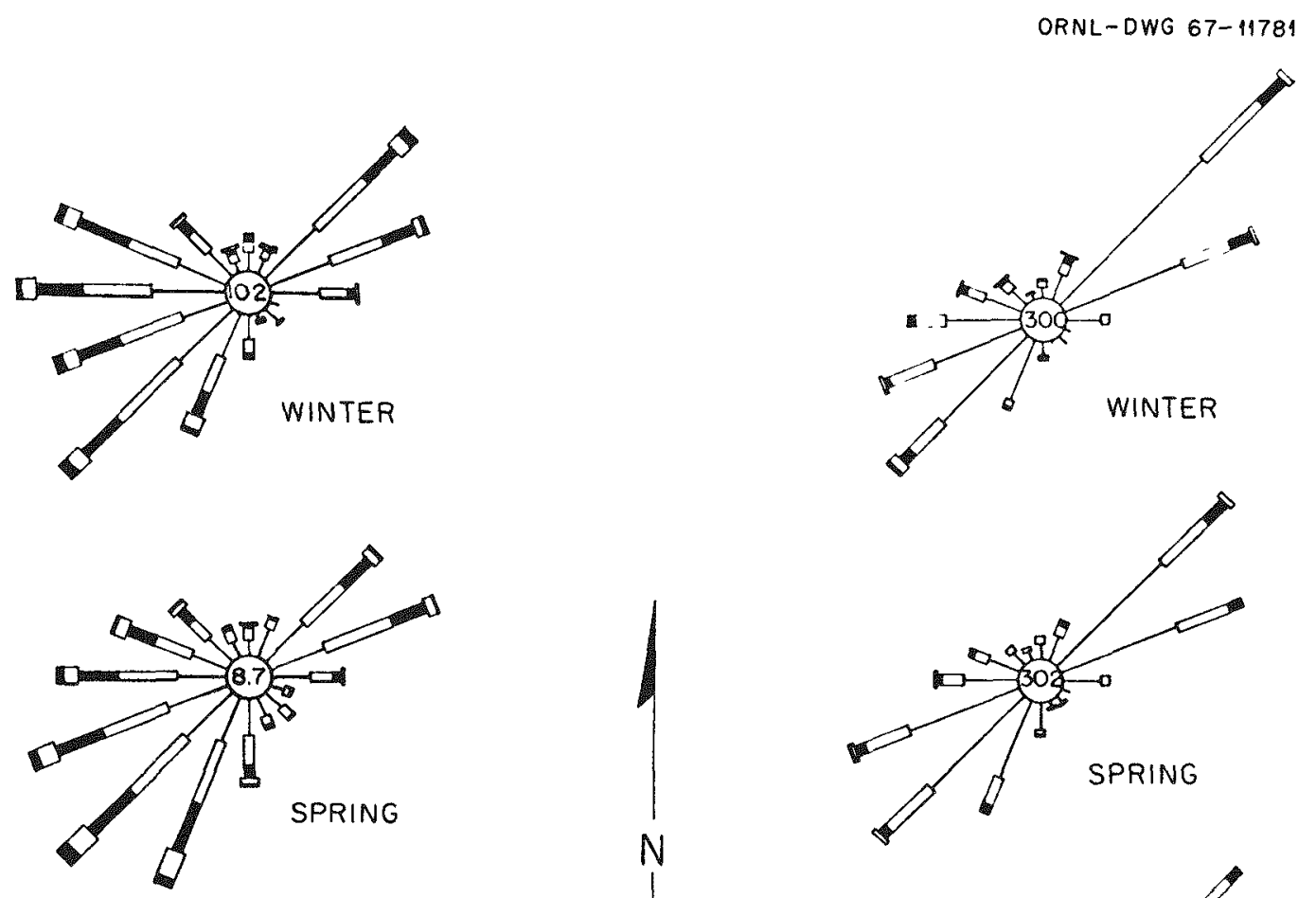

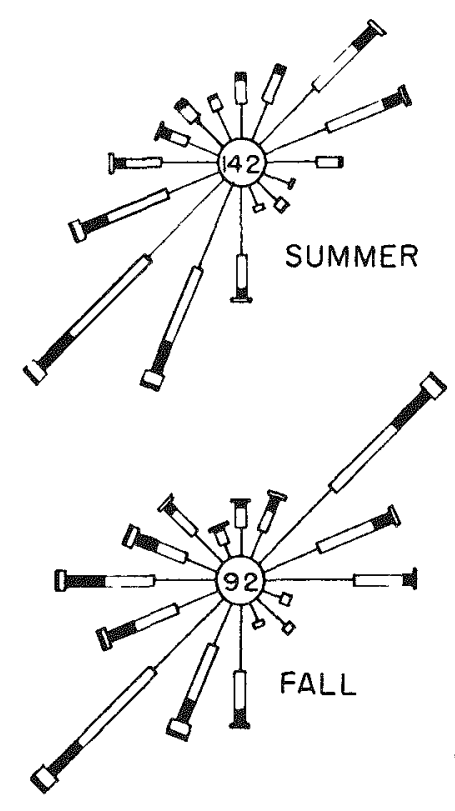

LAPSE

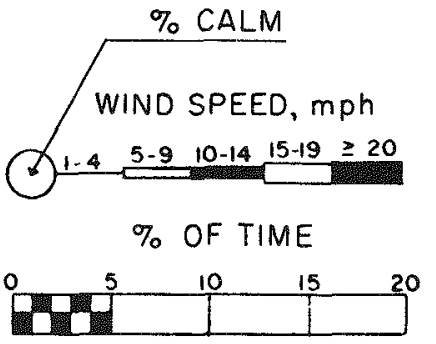

\%
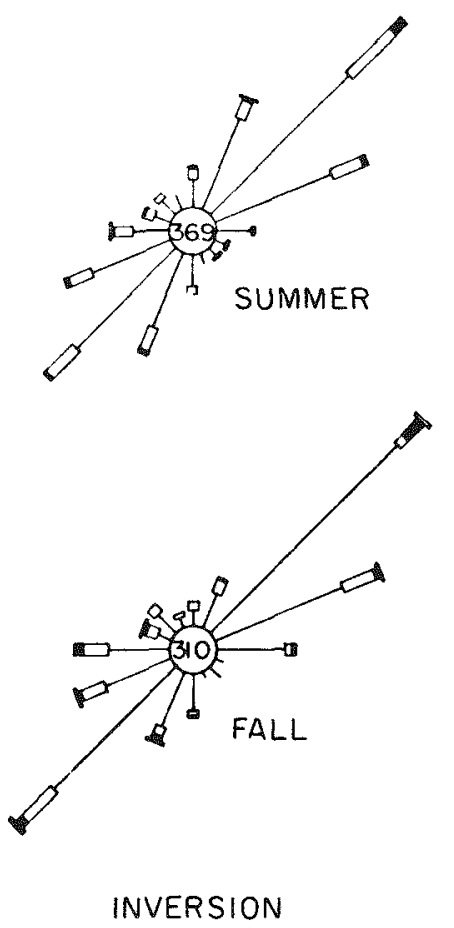

Fig. B.1. Wind Speed and Direction During Lapse and Inversion. 


\section{Geology_and Soils}

The geology and soils of the oak Ridge area have been reported on by several investigators. A generalized soils map which includes summarizations of mineralogical soil and rock types is given in Ref. B.1. A geologic map of the area is presented in Ref. B.2.

of particular importance to the present project is a discussion of the geologic features of White Dak Creek Basin, which is located in Roane county. Tennessee in the southern part of the oak Ridge Reservation. The Basin has an area of 6.01 square iles, and it arains to the Clinch River by way of white oak creek.

Four major rock units or formations occur in the Basin. In descending order of age, these are the Rome formation. underlying Haw Ridge: the Conasauga Group underlying chestnut Ridge and Melton Hill: and the chickamauga limestone,

underlying Bethel valley. These rocks originated early in the Paleogoic era as masine sediments and became uplifted toward the end of the era. A mantle of residual material is nearly everywhere present, extending to depths of 100 ft in some areas, particularly over the Rnox Dolomite.

Soils of the area are described in detail in Ref. B. 1. These belong prinarily to the broad groups of red-yellow podsolic, reddish brown lateric, and lithosols and are, in general, strongly leached, acidic, low in organic matter, and ith exchange capacities of less than 10 millieguivalent per 100 grams of soil. Depths of soil profiles within the basin vary from 6 in. in some of the shale and sandstone areas to more than $15 \mathrm{ft}$ in areas overlying dolomitic limestone and ithin alluial deposits along drainageways.

Soils derived from Knox Dolomite contain kaolinite as the principal clay fraction, those from the conasauga shale contain illite and vermiculite, and those derived from Chickamauga limestone contain a mixture of kaolinitic and ilitic naterials, with some units having significant montmorillonitic contents. The base saturation ranges from 10 to $60 \%$ within the various groups. The radionuclide specificity of the respective clay inerals has been determined, particularly with respect to the behavior of radioactive cesium. strontium, and cobalt, in sediments of White oak Lake and the Clinch River (Ref. B.3).

\section{Hydrology}

Drainage of the area is to the clinch River by way of various small streams. Included among these streams is white oak Creek, which courses through Oak Ridge Naticnal Laboratory and forms the principal drainage systen for the site. The average annual discharge measured at white oak Dam for the 
period 1968-1972 is 11 cfs.

within the area, major aquifers are associated with the Knox Dolomite formation. Water occurs to a lesser extent in small openings along points and bedding planes in the shale and sandstone rocks of Pottsville age and of the Rome Formation. Belts of residual naterials overlying bedrock are relatively thin. reducing the volume available for grounduater storage. conseguently. it is estimated that the average well in the oak Ridge area would yield less than 10 gpm (Ref. B.4). The clinch River, including its Melton Hili Lake impoundment has a drainage area of 4413 square miles, and it is the source of most of the vater in the area. Water pumped by the oak Ridge pumping station is delivered to ORNI the Y-12 Plant, and to the city of oak Ridge. Waste water from ORNL is returned to the clinch River via white oak creek, from the 1-12 Plant via East Fork Poplar creek, and from the city of Oak Ridge via East Pork Poplar Creek and ia a tributary at river mile 51.1. The Gaseous Diffusion plant $(K-25)$ is served by a separate pumping station. with vaste water from the plant being returned directly to the river.

operation of the TV multipurpose dams for flood control. navigation, and power generation results in regulated flow in the Clinch and Tennessee Rivers. Navigation locks are incorporated in a 11 dais on the Tennessee River and in Melton Hill Daw on the Clinch. During the vinter months, following cessation of heavy precipitation and runoff reservoir levels are raised to provide increased hydroelectric capability. subsequent power releases cause pulsations in river flows. Within the Clinch River, these discharges may reach 18,000 cfs, and they are not attenuated significantiy between welton Hill Dam and the mouth of white oak creek.

These high flow releases cause water levels to rise rapidly. blocking the outflow of water from white oak creek for about 6 hours each day. Upon cessation of power generation. the vaters of white oak creek begin to flow into the main stream and are flushed downstream with the next power release, becoming thoroughly mixed in about 7 miles

(Ref. B. 4).

Morton (Ref. B.5) observed that the dispersion process due to intermittent releases by Melton Hill Dam was not greatly different than that for steady flow conditions, and that downstream dye concentrations could be predicted on the basis of a uni-dimensional transport equation incorporating eddy diffusion coeficients conputed from steady-flow tracer tests.

In general, the waters of small strea ms in the oak Ridge area are of the calcium-magnesium-bicarbonate type. uncontaninated a jor sources range in hardness from oderate to very hard. with low contents of sodium, potassiun, and chloride (Ref. B. 4). No significant irrigation usage is apparent. 


\section{Seismology}

The oak Ridge Reservation lies in the southern Appalachian seismotectonic province, wich is characterized by a series of northeast to southwest trending folds and thrust faults in Paleozoic rocks. The region has been the source of continuing minor seismic activity. A chronological listing of the complete seismic history of the southeast region (including earthquakes with epicenters outside the region which produced detectable tremors within the specified area) is presented in Ref. B.6.

The epicenters of 270 earthquakes which occurred during the 40-year period. 1930-1969, are plotted in Fig. B. 2 according to their equivalent Richter magnitude. An approximate relationship is given bY $R=(2 / 3) \mathrm{M}+1$. where $R=$ Richter magnitude and = intensity. This plot does not include the two largest seismic events in the history of the southeast. These were the 1811-1812 shocks at New Madrid. Missouri. Intensity XI, and the 1886 shcck of Charleston. South Carolina. Intensity $x$. The intensity at the project site from these shocks was probably about VI or less. Two major centers of seistic activity are apparent from Fig. B.2. These centers are within the Mississippi Valley area and on the coast of south Carolina in the charleston area. A third zone of relatively high seismicity coincides with the southern portion of the Appalachian hountain geologic province.

A more detailed analysis of the seismicity of the southeastern united states can be obtained from an analysis of recurrence curves of the type shown in Fig. B.3. While the "fit" of the data are not good. extrapolation of the curve for the Southern Appalachian Region suggests a once-per-40-year quake of intensity VIII (modified Mercalli). a once-per-100-year shock of intensity IX, and a recurrence interval between destructive shocks of 106 years, as determined from statistical treatment of past records (Ref. B.6). Seismic evaluations of the Dak Ridge area suggest that within a 100-year period there exists a $50 \%$ probability for ground motion acceleration to exceed 0.03 to $0.09 \mathrm{~g}$.

\section{Area Access}

Access for other than employees to the USA EC Oak Ridge Reservation is limited to public roads. However, the public road network within the area is well developed. State highway 62 bisects the Reservation east and west, providing a direct route to knoxville. State highways 95 and 61 run north and south through oak Ridge, while 0 . S. Highway 25 "which connects Rnoxville. Tennessee, and Lexington. KentuckY, passes 4 miles northeast of the eastern boundary of the Reservation. Interstate Highway 40 connecting Rnoxville and Nashville. 


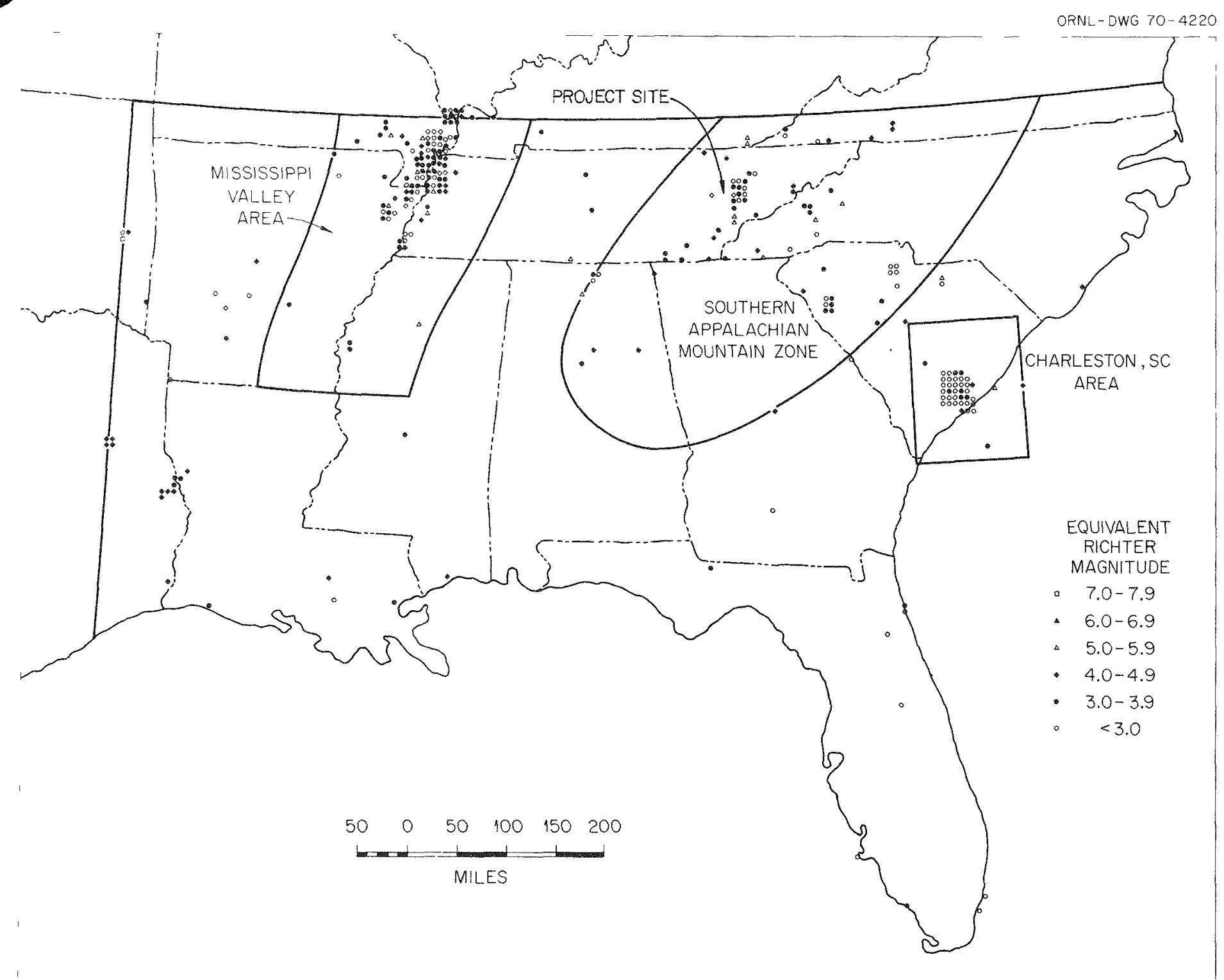

Fig. B.2. Epicenter Locations for Southeast Region Earthquakes in the Period 1930 Through 1969 . 

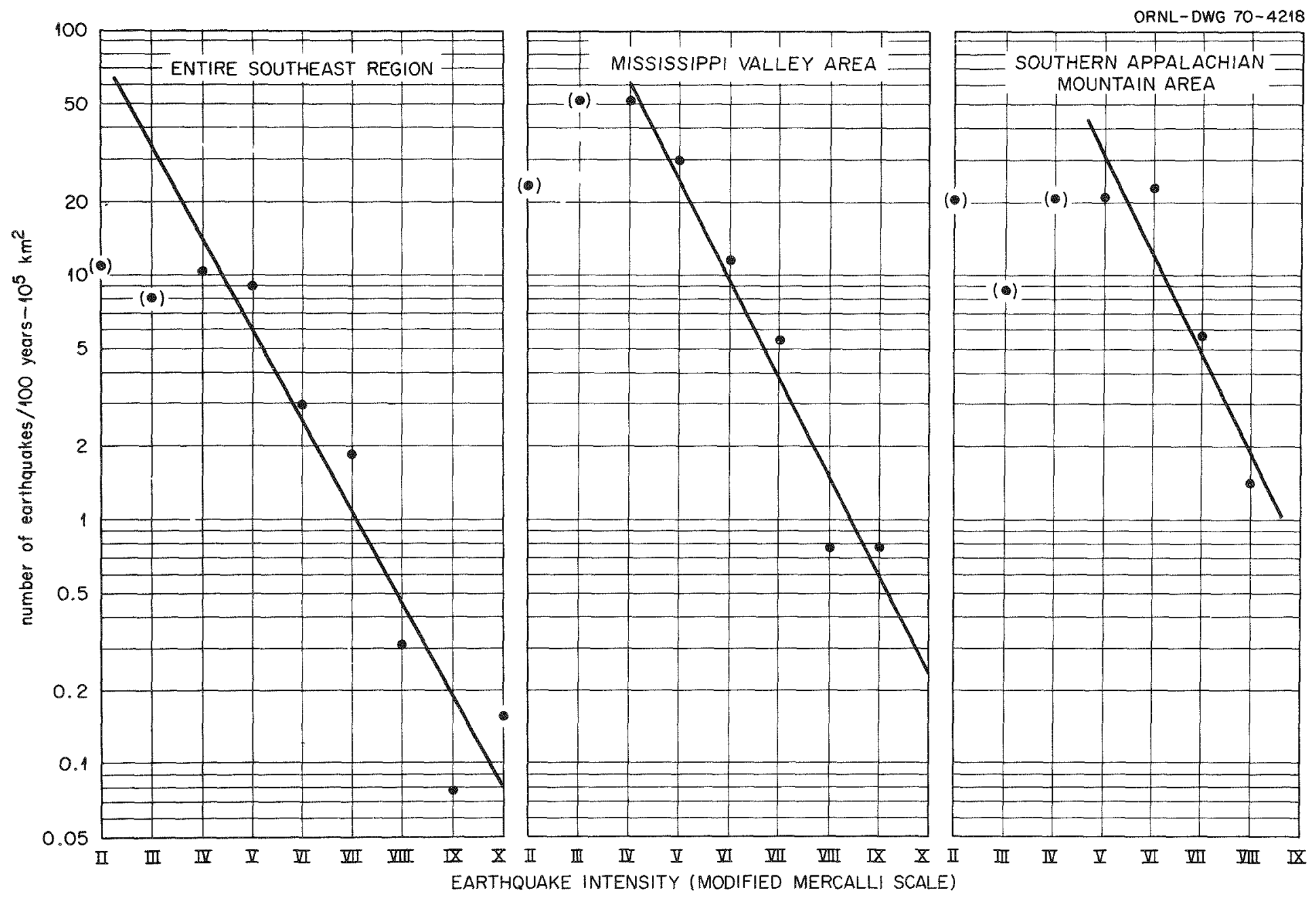

Fig. B.3. Recurrence Curves for (a) Total Southeast Region, (b) Mississippi Valley Area, and (c) Southern Appalachian Mountain Zone. (Curves represent least-squares fits of the relationship $\log \mathrm{N}=a+b I$, where $\mathrm{N}$ is the number of earthquakes per 100 years and per 100,000 $\mathrm{km}^{2}$ of intensity, I.) 
Tennessee. is 2 miles southeast of the western boundary of the Reservation. The primary and secondary road systen of the Reservation is excellent.

The area is adequately served by rail transportation. with connecting points located at Harriman. Tennessee. The Clinch River waterway forms the southern boundary of the Reservation and joins the Tennessee River syste 10 miles downstream. A-ft navigation channel extends above clinton. Tennessee, to Clinch River Mile 61.

\section{Ecology of site and Environs}

The Oak Ridge Reservation is tyical of the landscape and ecological systems which occur in the Appalachian Region of the eastern Inited states. As such, the area is comprised of a nuber of representative terrestrial and aquatic ecosystems that range from smaller, established southern coniferous forests to northern hardwood types and from small strea tributaries to man-made reservoir systems.

A preliminary inventory of the flora of the general oak Ridge area was completed in 1966 (Ref. B.7). This inventory has since been supplemented wh observations of spring flowering for 171 species of herbaceous and woody plants representing 55 plant families (Ref. B.8).

Five Appalachian forest types occur natura 11y on the Reservation (Ref. B.9). The oak-hickory type shares equal prominence with the yellow pine-hardwood type. cove hardwoods are found interspersed between dissected ridge systems, and northern hardwoods occurr in sheltered areas with northern exposures. minor type, white pine-hardwood, is found along the northern boundaries of the property. Between 1947 and 1950. large areas of open land vere planted to loblolly pine. creating a sixth forest type.

A detailed ap of the dominant vegetation within the immediate area of the proposed facility is illustrated in Fig. B.4. The area is relatively heavily wooded with a large proportion of the total cover being comprised of sweet gum and white and red oaks. Hellow poplar, ash, and red maple are present on more wesic sites, and short-leaf and irginia pine are scattered along coads and in open areas generally as a result of managed plantings.

There are several available studies describing the fauna of the area, with special reference to lelton valley wherein lies the site of the proposed fuel refabrication pilot plant. A 1958 survey of summer bird populations at 157 stations resulted in the recording of 1870 individuals representing 65 separate species (Ref. B.10). Density of individuals as highly correlated with vegetation cover with the greater numer of birds being observe in habitats characterized by 1ov growing herbaceous material interspersed with younger trees. greater diversity of species. with lesser numbers of individuals as found to be typical for forested habitats. 


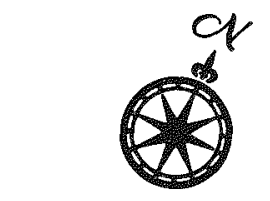

ORNL OWG $73-1614$

PART I
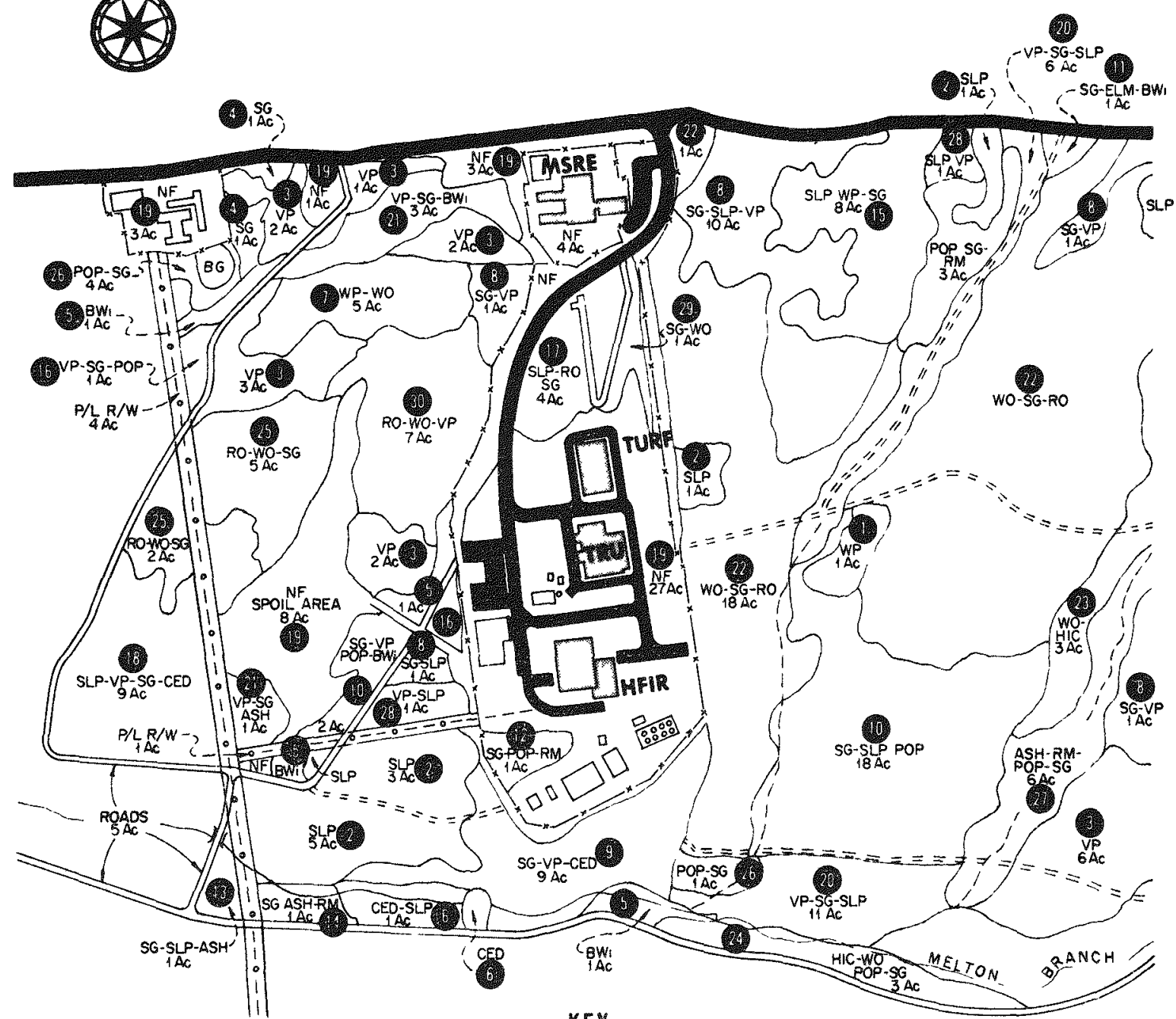

KEY

\begin{tabular}{clc}
\hline STRA \# & VEGETATION TYPE & ACRES \\
\hline 1 & WP & 1 \\
\hline 2 & SLP & 10 \\
\hline 3 & VP & 19 \\
\hline 4 & SG & 2 \\
\hline 5 & BWI & 3 \\
\hline 6 & CED, CED-SLP & 1 \\
\hline 7 & $W P-W O$ & 5 \\
\hline 8 & SG-VP, SG-SLP, SG-SLP-VP & 15 \\
\hline 9 & SG-VP-CED & 9 \\
\hline 10 & SG-SLP-POP, SG-VP-POP-BWI & 20 \\
\hline 11 & SG-ELH-BWI & 1 \\
\hline 12 & SG-POP-RM & 1 \\
\hline 13 & SG-SLP-ASH & 1 \\
\hline 14 & SG-ASH-RM & 1 \\
\hline 15 & SLP-WP-SG & 8 \\
\hline 16 & YP-SG-POP & 1 \\
\hline
\end{tabular}

\begin{tabular}{|c|c|c|}
\hline 17 & SLP-RO-SG & 4 \\
\hline 18 & SLP-YP-SG-CED & 9 \\
\hline 19 & NF BUILDING SITES & 46 \\
\hline 20 & VP-SG-SLP & 18 \\
\hline 21 & VP-SG-ASH, VP-SG-BWI-VP-SG-POP & 5 \\
\hline 22 & WO-SG-RO & 52 \\
\hline 23 & WO-HIC & 3 \\
\hline 24 & HIC-WO-POP-SG & 3 \\
\hline 25 & RO-WO-SG & 7 \\
\hline 26 & POP-SG, POP-SG-RM & 4 \\
\hline 27 & ASH-RM-POP-SG & 6 \\
\hline 28 & SLP-VP, VP-SLP & 2 \\
\hline 29 & SG-WO & $T$ \\
\hline 30 & $R O-W O-V P$ & 9 \\
\hline 31 & POWER LINE R/W & 5 \\
\hline 32 & ROADS & 5 \\
\hline & TOTAL ACREAGE & 275 \\
\hline
\end{tabular}

Fig. B.4. Vegetation Type Map for the Area Surrounding the TURF. 
ORNL DWG $73-1614$

PART 2

\begin{tabular}{lll}
\hline COMMON NAME & CODE & SCIENTIFIC NAME \\
\hline ASH & ASH & FRAXINUS SP. \\
\hline BLACK GUI & BG & NYSSA SYLVATICA \\
\hline CEDAR & CED & JUNIPERUS YIRGINIANA \\
\hline ELI & ELM & ULMUS AMERICANA \\
\hline HICKORY & HIC & CARYA SP. \\
\hline RED MAPLE & RM & ACER RUBRUI \\
\hline YELLOW POPLAR & POP & LIRIODENDRON TULIPIFERA \\
\hline NORTHERN RED OAK & RO & QUERCUS RUBRA \\
\hline SWEETCUM & SG & LIOUIDAMBAR STYRACIFLUA \\
\hline SHORTLEAF PINE & SLP & PINUS STROBUS \\
\hline BLACK WALNUT & BWI & JUGLANS NIGRA \\
\hline WHITE OAK & WO & QUERCUS ALBA \\
\hline WHITE PINE & WP & PINUS MONTICOLA \\
\hline VIRGINIA PINE & VP & PINUS VIRGINIANA \\
\hline
\end{tabular}

Legend for Fig. B.4.

Summer birds typical of habitats represented in Fig. $B .4$ include the red-eyed vireo. Carolina wren, tufted titmouse, carolina chickadee and numerous other pure forest as well as edge species.

In contrast to area bird populations, which were shown to be dependent upon vegetation cover. mamalian faunal makeup is more directly inked with soil fertility and depth of humus and litter layers (Ref. B.11). Typical species include mice, shrews, opossums, racoons, woodchucks, cottontail rabbits, and the gray fox. White-tail deer have been observed in the area. and appear to be increasing in numbers, as evidenced by an increasing frequency of road kills on the Reservation.

The herpetofauna of the area have been described. including a categorization of habitat types (Ref. B.12). Various species of salamanders turtles, frogs and toads. lizards, and snakes, including the northern copperhead, make up this particular component of the area's biota. Various facets of the aquatic syste represented by the white oak Creek-White oak Iake-Clinch River-Tennessee River continuum, have been studied over the past several decades, particularly ith regard to the behavior and transport of radioactive materials in the aquatic environment (Ref. B.13). For the most part these investigations vere conducted prior to the establishment of welton Hil Reservoir, and they were primarily concerned with selected organisms (e.g.. tubificid vorms, crayfish, Chironomid larvae, clams, and several species of fish, including white crappies, carp, and smallmouth buffalo) as they related to the transport of radioactive materials.

A characterization of fishes common to the clinch River system prior to the establishment of Melton Hill Reservoir 
(Ref. B. 13) showed major groups to include the Centrarchidai (sunfishes, basses and crappies). Catostomidae (suckers), and Ictaluridae (catfishes). Bxcept for carp, the cyprinidae (minnows) were poorly represented, primarily due to a lack of suitable habitat. Forage for piscivorous fish is provided by large populations of clupeidae (threadin shad, gizzard shad). In addition to the above groups, sauger and white bass, both carnivorous species, are regularly caught.

The fisheries resources of the Tennessee River system are exploited by both commercial and sports fishermen. Some comercially harvested nongame species (e.g., carp, buffalo) are marketed for human consumption. Records of commercial takes from the Tennessee River, 1946-1963, show harvests ranging from a 10 of $1.073,0001 \mathrm{~b}$ in 1947 to $8.532 .0001 \mathrm{~b}$ in 1963. comprised mainly of catfish and buffalo (Ref. B.13). Typical of the present aquatic system downstream from Helton Hill Reservoir and immediately adjacent to the proposed facility is the biotic composition of White oak Lake at ORNL. The lake has been characterized as having high phytoplankton productivity and a well-developed benthic fauna, with the most common forms being comprised of various insect larvae (Ref. B. 14). Fishes present in the shallow embayment (maximum depth $7.3 \mathrm{ft}$ include bluegill and redear sunfish. largemouth bass, warmouth, gizzard shad, golden shiners, goldfish, and the osquitofish, Gambusia affinis affinis.

\section{Land Use}

The 92-square-mile oak Ridge Reservation was originally acquired as a site for production facilities and nuclear research, and a security buffer and safety zone were established around each AEC plant. The original 59,000 acres acquired in 1942 have since been reduced to approximately 37,000 acres through land transfers to the municipal government and to state and federal agencies (Ref. B.9). A study of aerial photographs made in 1942 indica tes that about 43\% of the area was at that time comprised of pastures and flelds. The remaining areas vere forested.

The a mount of timber harvested for construction of the oak ridge facilities is unknown. In 1947, Management services Incorporated, an AC contractor, began a reforestation program Which ended in 1960. During that period, approximately 9 million pine seedlings were planted in old field and open areas to the extent that as of 1965, approximately 4300 acres of shortleaf. loblolly, and eastern white pine plantations existed in the Reservation (Ref. B.9).

A 1961 survey of forest lands by the TVA sumarized then extant timber resources of the Reservation, leading to the establishment of a forest management program at ORNL in 1964. The present allocation of land use among plant installations is given in Table 3 (subsection II.D.6). Buffer 
areas around each of the facilities provide increased security and protection against accidental release of chemical or radioactive materials and also provide room for future expansion. Little forested acreage is included in the buffer areas around the $\mathbb{T}-12$ and $R-25$ plants, but extensive forested areas lie within the ORN and UT-AEC sections. Excluding buffer areas around USABC facilities, the remainder of the Reservation is subdivided into 24 management compartments that range in size fro 400 to 1200 net manageable acres (Ref. B.9). Approximately 93\% of the total manageable land $(15,000$ acres) is forested in pine $(36 \%)$. upland hardwoods (32\%), mixed pine-hardwoods $(21 \%)$, and cedar and miscellaneous species $(11 \%)$.

Objectives of the present forest mangement plan are a maximization of yield and quality of timber resources to assure a substantial yield of high-quality stumpage within the constraints of primary research and production objectives of the AC facilities. Twenty-five research areas, totalling 2300 acres, are reserved for ecological studies. These areas provide a variety of landscape units for research and permit the use of a holistic approach to ecosystem analysis. It was recently proposed that the oak Ridge Reservation be designated an Environmental study Park (Ref. B.15). Within this context. a total of 41 study areas were delineated as being unique and important in terms of present-day environmental problems. The location of the existing TORF and its conversion as proposed herein ill not jeopardize or exert an measurable influence on any of the designated study areas.

One historic landmark, the Oak Ridge Graphite Reactor, is located on the USAEC Oak Ridge Reservation at Oak Ridge National Laboratory.

\section{Regiona1_Demograah표}

As previously discussed, the proposed HTGR Fuel Refabrication pilct Plant is to be installed in the existing TORF, which is located in the lelton valley area of oak Ridge National laboratory. Incremental population data, based on the 1970 United states Census, out to a distance of 70 miles in all directions from the TURF site are given in Table B.2. The total population in this area is 1.025 .864 . The two largest cities near the plant site are knoxville, Tennessee, and oak Ridge, Tennessee. The city limit of Knorville, which has a population of 175,000 , is approximately 13 miles toward the east of the plant site. The populated area of Oak Ridge (population, 28,000) begins at approximately 5 iles north of the plant site. 
Table B.2. Incremental Population Data for TURF Site

\begin{tabular}{|c|c|c|c|c|c|c|c|c|c|c|c|c|}
\hline \multirow[b]{2}{*}{ Direction } & \multicolumn{12}{|c|}{ Distance (miles) } \\
\hline & $\overline{0-1}$ & $1-2$ & $2-3$ & $3-4$ & $4-5$ & $5-10$ & $10-20$ & $20-30$ & $30-40$ & $40-50$ & $50-60$ & $60-70$ \\
\hline $\mathrm{N}$ & 0 & 0 & 0 & 0 & 1,490 & 5,578 & 2,177 & 1,441 & 2,223 & 4,509 & 13,686 & 7,314 \\
\hline NNE & 0 & 0 & 0 & 0 & 1,461 & 13,783 & 4,362 & 11,189 & 12,674 & 6,119 & 7,978 & 17,980 \\
\hline$N E$ & 0 & 0 & 0 & 0 & 0 & 9,713 & 12,479 & 7,167 & 4,392 & 7,476 & 21,097 & 8,781 \\
\hline ENE & 0 & 0 & 0 & 0 & 0 & 0 & 27,462 & 74,686 & 18,723 & 13,872 & 23,240 & 31,800 \\
\hline $\mathrm{E}$ & 0 & 0 & 0 & 0 & 0 & 3,059 & 44,883 & 100,488 & 11,793 & 12,900 & 8,965 & 21,468 \\
\hline ESE & 0 & 0 & 0 & 0 & 0 & 6,096 & 5,363 & 36,015 & 4,132 & 6,840 & 346 & 0 \\
\hline $\mathrm{SE}$ & 0 & 0 & 0 & 0 & 0 & 1,167 & 4,304 & 15,010 & 46 & 0 & 0 & 0 \\
\hline SSE & 0 & 0 & 0 & 0 & 1,374 & 7,277 & 1,200 & 4,091 & 469 & 0 & 0 & 0 \\
\hline S & 0 & 0 & 0 & 0 & 0 & 943 & 8,742 & 7,309 & 6,560 & 1,222 & 4,101 & 2,055 \\
\hline SSW & 0 & 0 & 0 & 0 & 0 & 721 & 2,055 & 7,897 & 21,582 & 10,527 & 17,018 & 34,253 \\
\hline SW & 0 & 0 & 0 & 0 & 0 & 733 & 1,840 & 1,909 & 3,962 & 8,578 & 10,312 & 21,909 \\
\hline WSW & 0 & 0 & 0 & 0 & 0 & 622 & 9,862 & 3,495 & 4,562 & 4,204 & 5,894 & 2,799 \\
\hline W & 0 & 0 & 0 & 0 & 0 & 666 & 13,099 & 4,595 & 9,038 & 7,318 & 4,129 & 14,856 \\
\hline WNW & 0 & 0 & 0 & 0 & 0 & 587 & 2,971 & 1,543 & 0 & 4,151 & 5,055 & 29,862 \\
\hline $\mathrm{NW}$ & 0 & 0 & 0 & 0 & 0 & 1,073 & 4,804 & 1,538 & 1,896 & 7,552 & 2,396 & 9,358 \\
\hline NNW & 0 & 0 & 0 & 0 & 0 & 1,495 & 0 & 1,152 & 4,559 & 4,676 & 2,097 & 8,030 \\
\hline Total & 0 & 0 & 0 & 0 & 4,325 & 53,518 & 145,673 & 279,525 & 106,611 & 99,433 & 126,314 & 210,465 \\
\hline
\end{tabular}




\section{References}

B.1. Dorothy Carroll, "Soils and Rocks of the Oak Ridge Area, Tennessee," USAEC Trace Elements Investigations Report 785 , June 1961.

B.2. M. M. Master, "Geologic Map of the oak Ridge Reservation. Tennessee," OSAEC Report ORNL-TM-713, Oak Ridge National Laboratory. 1964.

B.3. P. H. Carrigan, Jr. R. J. Pickering, T. Tamura, and R. Forbes, "Radioactive Materials in Bottom Sediment of Clinch River: Part $A$, Investigations of Radionuclides in opper Portion of sediment," USAEC Report ORNL-3721, Supplement 2A, Oak Ridge National Laboratory. 1967.

B.4. W. Master, "Hydrologic Data for the oak Ridge rea, Tennessee, "Geological Survey Water-Supply Paper, $1839-N, 1967$.

B.5. R. J. Morton, Eaitor, "Status Report No. 5 on Clinch River Study." USAEC Report ORNL-3721, Oak Ridge National Laboratory. 1965.

B.6. W. C McClain and $O$. H. Meyers, "Seismic History and Seismicity of the southeastern Region of the United States, "USABC Report ORNL-4582, Oak Ridge National Laboratory. 1970 .

B.7. J. S. Olson, G. Cristofolini, and S. Cristofolini, Editors, "Oak Ridge, Tennessee, Flora: 1. preliminary Alphabetic Inventory of Vascular Plants, "USAEC Report ORNI-TM-1232, Oak Ridge National Laboratory, 1966.

B.8. F. G. Taylor, Jr., "Oak Ridge, Tennessee, Flora: 2. Spring Flowering Dates, "university of Tennessee Arboretunㅗ society Bulletin, $4: 13-19$ (1969).

B.9. J. M. Curlin, "Porest hanagement Plan, laC oak Ridge Reservation," USAEC Report ORNL-TM-1317, Oak Ridge National Laboratory, 1965.

B.10. J. C. Howe11, "Long-Range Ecological Study of the oak Ridge Area: 1. Observations of the sumer Birds in Melton Valley." USAEC Report ORNL-CF-58-6-14, Oak Ridge National I aboratory, 1958.

B.11. J. C. Howell and P. B. Dunaway, "Long-Term Ecological study of the Oak Ridge Area: II. observations of the Mamals ith Special Reference to Melton Valley." USA EC Report ORNL-CF-59-10-126, Oak 
Ridge National Laboratory. 1959.

B.12. R. M. Johnson, "The Herpetofauna of the oak Ridge Area," USAEC Report ORNL-3653, Oak Ridge National Laboratory. 1964 .

B.13. Clinch River steering Comittee " Comprehensive Report of the Clinch River Study, USAEC Report ORNt-4035, Oak Ridge National Laboratory. 1967.

B.14. S. E. Kolehmainen and D. J. Nelson, The Balances of $137 \mathrm{Cs}$, stable cesium, and the reeding Rates of Bluegill (Leporis macrochirus Raf.) in thite oak Lake." USAEC Report ORNL-4 445, Oak Ridge National Laboratory. 1969.

B.15. Union Carbide Corporation. Nuclear Division. "Proposal to Designate the AEC Oak Ridge Reservation as an Environmental study Park, "Oak Ridge National Laboratory unumbered publication. Novenber 1972. 


\author{
Appendix C \\ ENVIRONMENTAL MONITORTNG OF EXISTING ENVIRONMENT
}

The oak Ridge National Laboratory conducts a continuous program of surveillance over the oak kidge reservation and its surrounding environs to monitor all types of environmental pollution. This program has been in effect for approximately 30 years to assure the continuing safety and protection of installation personnel and the general public. Similar programs of surveillance are conducted at the oak Ridge $Y-12$ Plant and the oak Ridge Gaseous Diffusion Plant $(R-25)$ which are close bl and share the same environment. 11 programs are coordinated by the inter-plant office of safety and Environmental protection.

\title{
Radioactive Effluents
}

Information derived from the ORNL radioactivity monitoring program is contained in the "Annual Environmental Monitoring Report, USAEC Oak Ridge Facilities" issued by the union Carbide office of Safety and Environmental Protection. In adition. the ORNL Inspection Engineering Department issues reports on testing of pollution control devices chiefly filters.

\section{Atmospheric Releases}

tmospheric releases are monitored with in-plant and in-stack monitors, a local air monitoring network, perimeter air monitoring network, and remote air monitoring network, and a milk sampling network.

(a) In=plant and In-stack ponitors. It has been a long-standing policy to wontor a 11 effluents at the points of release to the environment to obtain accurate estimates of total releases. Monitoring data indicate that yearly releases have decreased steadily although operations involving radioactivity are still idespread and the sensitivity and accuracy of monitoring equipment have in proved.

(b) Loca1 Air Monitoring IAl Network. Ntwospheric contamination and fallout on the ORNI site are on 1 tored 1 th continuous airflow filters, fallout trays, and rain collectors. There are 22 onitoring stations hich comprise the LAM network at ORNL. Three of these stations are located in the felton Valley area, and one of these (station 20) is adjacent to the TURF. The real-time readings for instruments at all IA sites are telemetered to a central readout panel. 
(c) Perimeter Air Monitoring (PAM) Network. The PAM network consists of nine stations located on the perimeter of the AEC-controlled area, as illustrated in Fig. C.1, and it provides data for evaluation of the impact of all oak Ridge operations on the immediate environment. These stations are siluilar to the ones in the cal network, and the readings are also continuously telemetered to a central ceadout panel.

(d) Remote Air Monitoring (BA Network. The Ram network consists of eight stations located outside the AEC-controlled area at distances of from 12 to 75 miles from ORNL, as is shown in Tig. C.2. This system provides data to aid in the evaluation of local conditions and to assist in determining the spread or dispersal of contamination if a major incident should occur.

lel_mik Sampling Network. samples of rav mik are collected at 12 sampling stations located within a radius of 50 miles of ORNL. Samples are taken on a weekly basis from the eight stations shown in Fig. C.3. These stations are located outside the ACC-controlled area vithin a 12-nile radius of ORNL. Samples are collected every 5 weeks from the four remaining stations, all of which are located outside the 12-mile radius up to distances of about 50 iles. The samples are prepared in a radioanalytical laboratory for counting iodine-131 and strontiu -90 .

\section{Liquid Releases}

Lom-level radioactive liquid wastes originating from oRN operations are discharged. after preliminary treatment, to white oak creek. which is a small tributary of the clinch River. The radioactive content of the white oak creek discharge is determined at hite oak Daw, which is the last control point along the strea prior to the entry of white oak creek into the clinch River.

(a) In-Plant Monitors. 11 facilities at ORNI are equipped ith continuously operating radiation monitors. Radiation and contamination detection and alarm systems are installed in the TURF to continuously and automatically monitor the air contamination level and gama and neutron radiation levels.

(b)-White oak Dan Monitoring station. Sa ples of white oak creek effluent are collected at white oak Dal by a continuous strea flow proportional samler. The samples are analyzed reekly for transuranic alpha emitters, total

strontium. and iodine-131. Composite samples are analyzed for all individual radionuclides present in detectable quantities. The onitoring station at wite oak Da provides information to deter ine the percentage distribution and concentrations of 


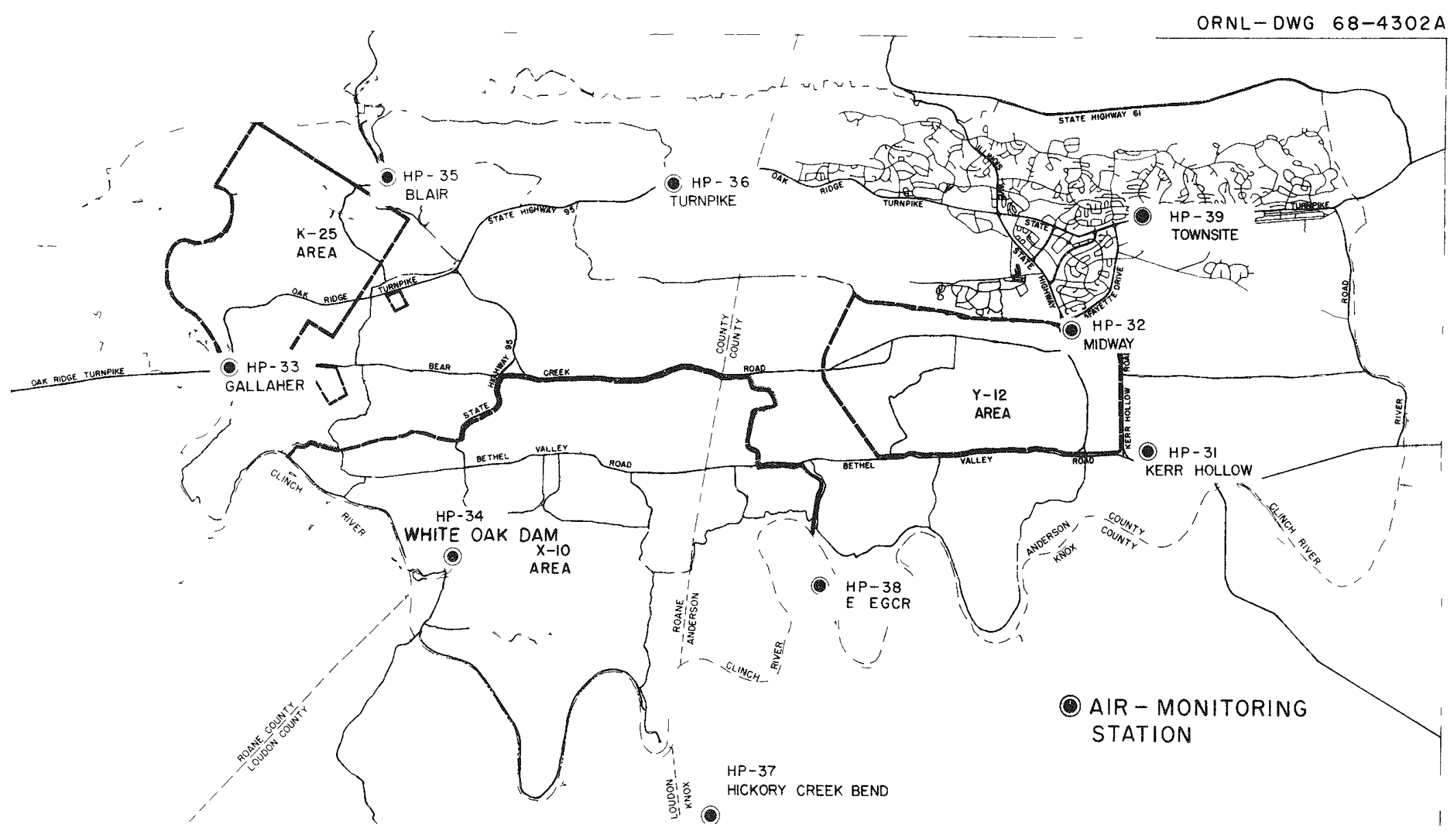

Fig. C.1. Perimeter Air Monitoring (PAM) Network. 


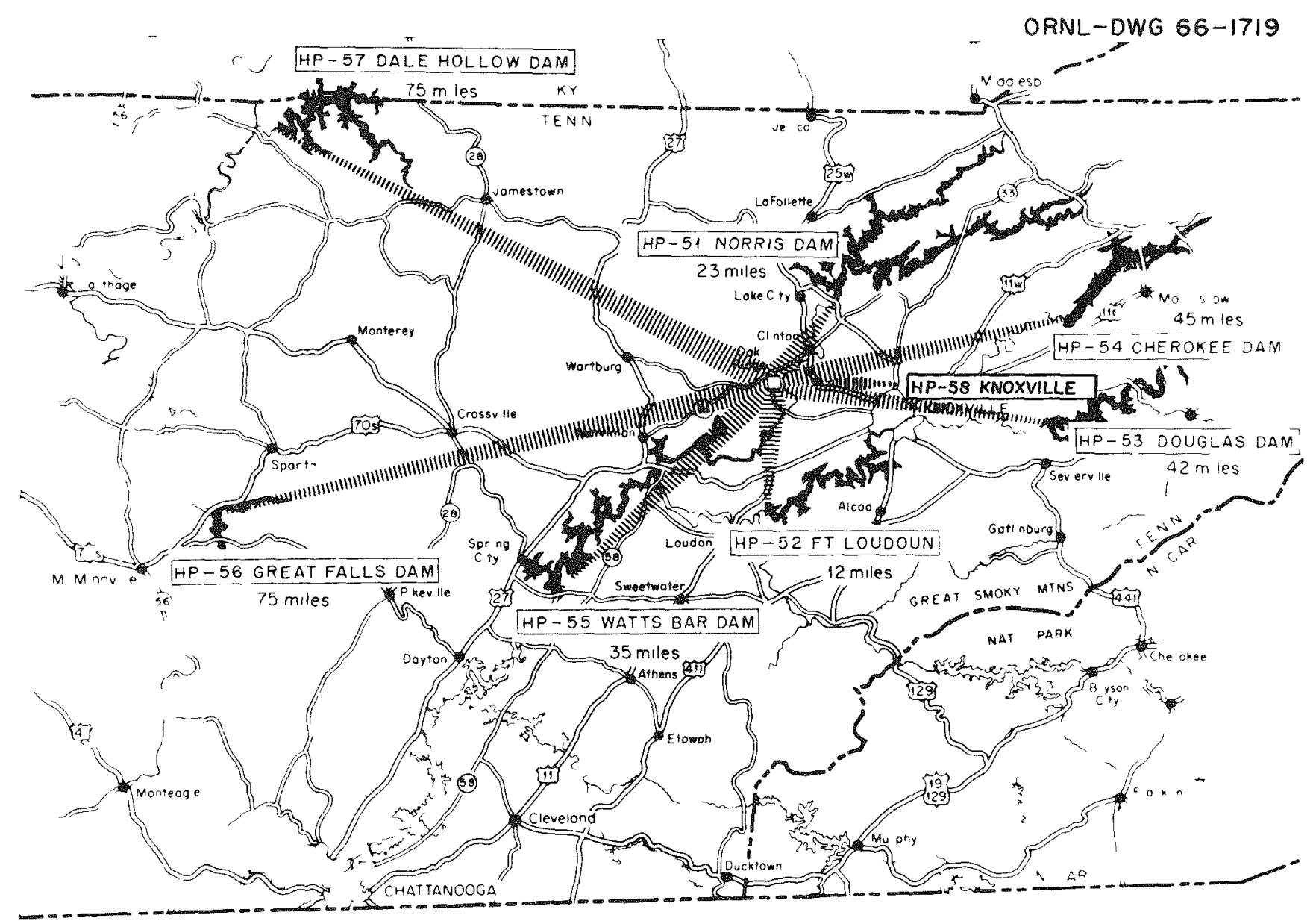

Fig. C.2. Remote Air Monitoring (RAM) Network. 


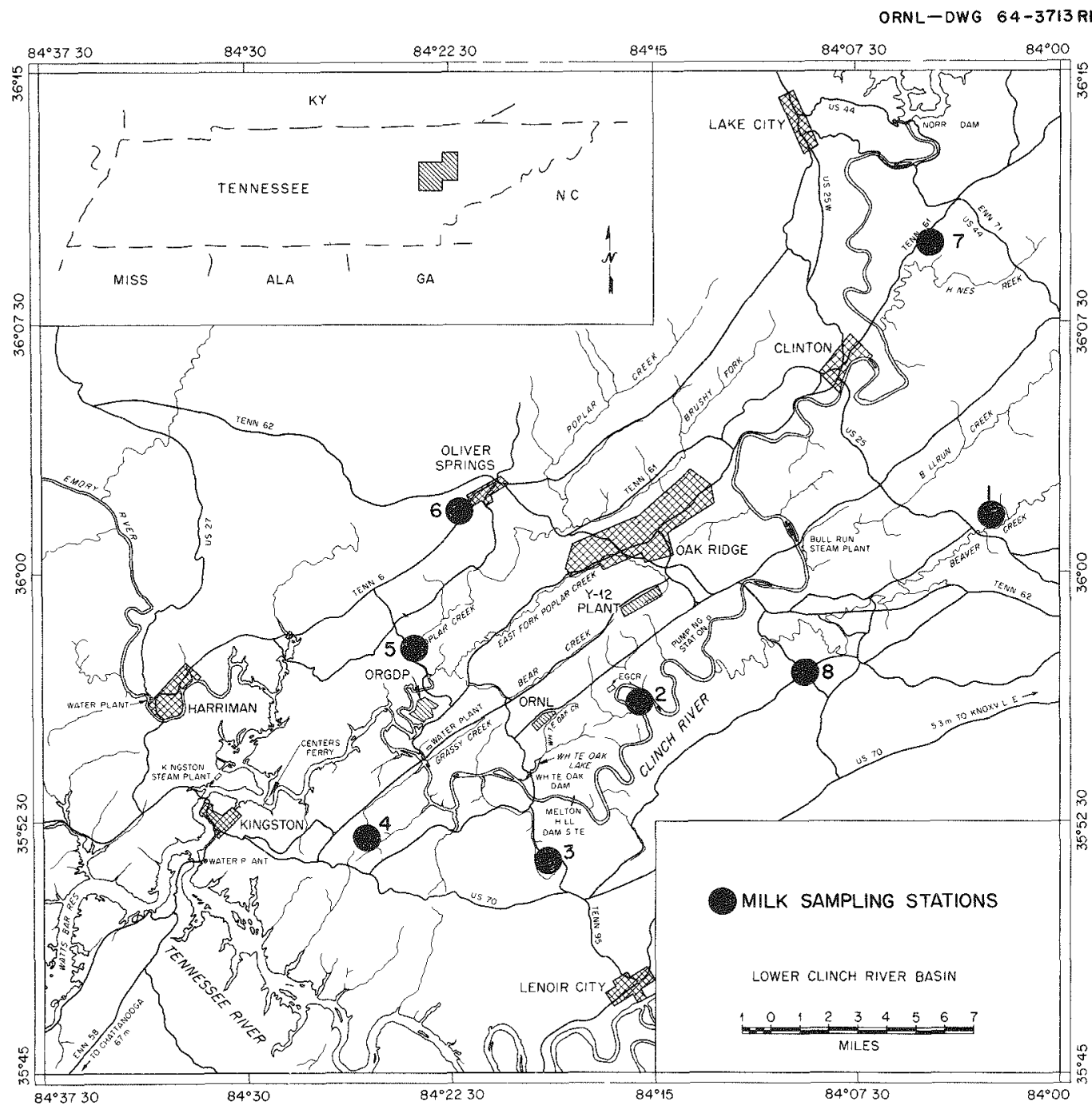

Fig. C.3. Location of Milk Sampling Stations.

the various radionuclides in the effluent strea and to calculate the quantity of each radionuclide released to the Clinch River.

(c) Clinch River Monitoring stations. As a follow-up to monitoring at wite Oak Dam, two sampling stations are maintained in the clinch River below the point cf entry of the wastes. One is located at the water intake to the Oak Ridge Gaseous Diffusion Plant, and the other is located at Centers Perry, near kingston. Tennessee. Background or comparison data are provided by a sampling station at Melton Hill Dam. located upstrea from the confluence of white oak creek and the Clinch River. 


\section{Nonradioactive Effluents}

A surveillance progra for assessing effluent waste maters from ORNI and the subsequent levels of chemical pollutants in the Clinch River has been in operation since 1962. The locations of six sampling points are shown on Fiq. C.4. 


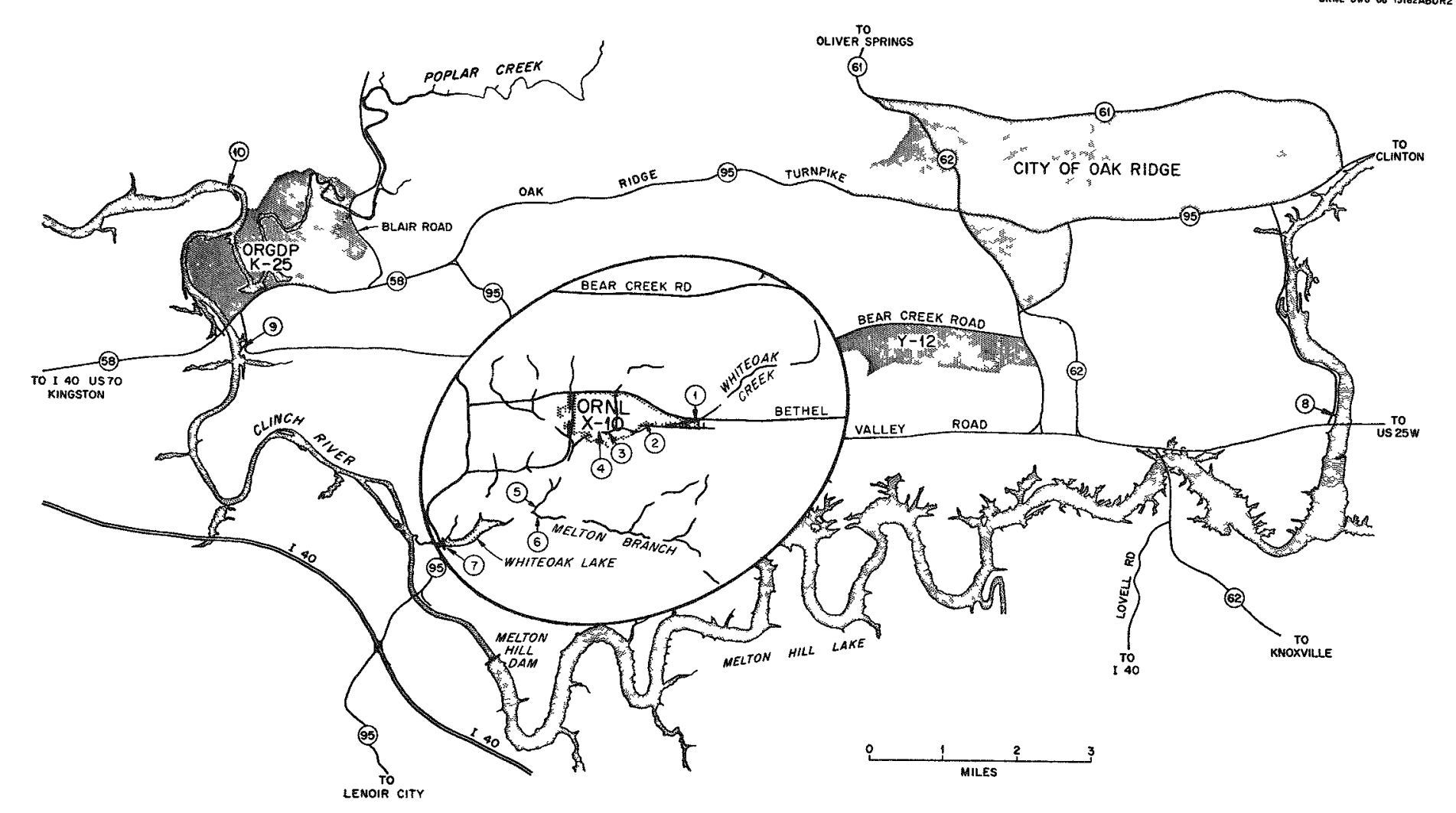

Fig. C.4. Location of Sampling Stations for Nonradioactive Effluents. 
Appendix D

ATMOSPHERIC DISPERSION OF STACK RELEASES

The equation used to estimate the radionuclide air concentrations at ground level is the Gaussian plume equation of Pasquill ${ }^{1}$ as modified by Gifford.2

$$
x=\frac{Q}{\pi \sigma_{y} \sigma_{z} \mu} \exp \left(-\frac{y^{2}}{2 \sigma_{y}^{2}}-\frac{h^{2}}{2 \sigma_{z}^{2}}\right)
$$

where

$x=$ radionuclide concentration in air at ground level at a point $\mathrm{x}$ meters downwind from the plant and $\mathrm{y}$ meters in the crosswind direction, $\mathrm{Ci} / \mathrm{m}^{3}$,

$Q=$ uniform rate of release of the radionuclide from the plant, $\mathrm{Ci} / \mathrm{sec}$,

$\mathrm{y}=$ distance crosswind from the center line of plume, $\mathrm{m}$,

$\mathrm{h}=$ effective stack height, $\mathrm{m}$,

$\mu=$ wind speed, $\mathrm{m} / \mathrm{sec}$,

$\sigma_{\mathrm{y}}=$ horizontal dispersion coefficient, $\mathrm{m}$, and

$\sigma_{\mathrm{z}}=$ vertical dispersion coefficient, $\mathrm{m}$.

The downwind distance $(x)$ comes into the Pasquil1 equation through the parameters $\sigma_{y}$ and $\sigma_{z}$, which are functions of both $x$ and the degree of atmospheric stability. Pasquill devised a classification scheme for atmospheric stability that consists of six categories ranging from $\mathrm{A}$, the most turbulent category, to $F$, the most stable category. The plume disperses rapidly in both the horizontal and vertical directions in category $\mathrm{A}$, and it disperses slowly in category $F$. Plots of $\sigma_{y}$ and $\sigma_{z}$ as a function of $x$ for each of the six atmospheric stability categories derived from Pasquill's classification scheme can be found in the USAEC report Meteorology and Atomic Energy $1968 .^{3}$

The meteorological information required to compute average groundlevel air concentrations of a radionuclide as a function of distance and direction from a plant uniformly releasing a radionuclide from its stack is 
1. the annual frequency of each of the six Pasquill atmospheric stability categories,

2. the annual frequency with which the wind blows toward each of 16 directions away from the plant, and

3. wind speeds as a function of wind direction and atmospheric stability category.

Meteorological data for the plant site, based on U. S. Weather Bureau observations, are given in Tables D. 1 and D.2 for $\mathrm{C}$ and $\mathrm{E}$ stabilities, the two generalized stabilities applicable to the area.4

The effective stack height, $h$, in the Pasquill equation is the sum of the physical stack height, $h_{0}$, and the plume rise, which is $\mathrm{k} / \mu$ for a plume rise resulting from momentum. The physical stack height is 80.8 meters and the stack constant, $k$, is 29 meters $s^{2} / \mathrm{sec}$.

An effective perimeter was established for the AEC-controlled reservation with respect to the plant site." Dilution factors at ground level were obtained in a computer run using the input data of Tables D. 1 and D.2. The dilution factors for each direction from the stack at the distance in meters at the edge of the effective area perimetex are given in Table D.3. The log polar isopleths of expected annual average stack dilution factors for the plant site are shown in Fig. D.1. A low inversion lid was assumed for category $\mathrm{E}$, and this maximizes the ground-1evel air concentrations for this category because it imposes a restriction on vertical dispersion. No correction was made for ground deposition of particulates. The dilution factors in Table D.3 are thus maximized because a plume is depleted by particle deposition.

The least dilution occurs in the northeast sector and results in a $X / Q$ of $2 \times 10^{-7} \mathrm{sec} / \mathrm{m}^{3}$ (see Table D.3). This conservative $X / Q$ is used to dilute the expected annual average atmospheric releases 1 isted in the text. 
Table D.1. Frequency of Wind Speed and Wind Direction Under C-Stability

Conditions at Oak Ridge National Laboratory (Based on Observations Made by the United States Weather Bureau)

\begin{tabular}{lcccccccc}
\hline \multirow{2}{*}{$\begin{array}{c}\text { Wind } \\
\text { Direction }\end{array}$} & 0.5 & 2.5 & 7.0 & 12.0 & 17.0 & 22.0 & 27.0 \\
\hline & \multicolumn{1}{c}{ Nind Speed (Miles per Hour) } \\
\hline SSW & 0.001065 & 0.002813 & 0.004800 & 0.004610 & 0.003561 & 0.002337 & 0.000238 & 0.000016 \\
SW & 0.001828 & 0.005818 & 0.009219 & 0.008774 & 0.005102 & 0.002766 & 0.000366 & 0.000016 \\
WSW & 0.001319 & 0.003513 & 0.005977 & 0.003942 & 0.001701 & 0.000397 & 0.000016 & 0.0 \\
W & 0.001780 & 0.004753 & 0.004514 & 0.001749 & 0.000397 & 0.000207 & 0.000016 & 0.000016 \\
WNW & 0.001001 & 0.001812 & 0.001399 & 0.000477 & 0.000032 & 0.000048 & 0.000016 & 0.0 \\
NW & 0.001272 & 0.002225 & 0.001510 & 0.000525 & 0.000111 & 0.000064 & 0.0 & 0.000032 \\
NNW & 0.001303 & 0.002051 & 0.002003 & 0.000954 & 0.000334 & 0.000191 & 0.000079 & 0.000032 \\
N & 0.002051 & 0.005341 & 0.008854 & 0.005945 & 0.003227 & 0.002066 & 0.000477 & 0.000318 \\
NNE & 0.001685 & 0.005293 & 0.010221 & 0.006469 & 0.003449 & 0.001764 & 0.000620 & 0.000207 \\
NE & 0.002607 & 0.008758 & 0.013543 & 0.008536 & 0.003227 & 0.001446 & 0.000350 & 0.000302 \\
ENE & 0.001240 & 0.004546 & 0.008266 & 0.007566 & 0.003052 & 0.001828 & 0.000604 & 0.000493 \\
E & 0.001224 & 0.004006 & 0.008138 & 0.008917 & 0.005786 & 0.003481 & 0.001256 & 0.000445 \\
ESE & 0.000381 & 0.002273 & 0.003815 & 0.005818 & 0.003672 & 0.001987 & 0.000477 & 0.000127 \\
SE & 0.000381 & 0.001780 & 0.003799 & 0.003910 & 0.002130 & 0.001160 & 0.000159 & 0.000048 \\
SSE & 0.000302 & 0.001160 & 0.001907 & 0.001319 & 0.000890 & 0.000318 & 0.000048 & 0.0 \\
S & 0.000556 & 0.002130 & 0.002655 & 0.001764 & 0.000922 & 0.000556 & 0.000048 & 0.0 \\
\hline
\end{tabular}


Table D.2. Frequency of Wind Speed and Wind Direction Under E-Stability

Conditions at Oak Ridge National Laboratory (Based on Observations Made by the United States Weather Bureau)

\begin{tabular}{|c|c|c|c|c|c|c|c|c|}
\hline \multirow{2}{*}{$\begin{array}{c}\text { Wind } \\
\text { Direction }\end{array}$} & \multicolumn{8}{|c|}{ Wind Speed (Miles per Hour) } \\
\hline & 0.5 & 2.5 & 7.0 & 12.0 & 17.0 & 22.0 & 27.0 & 29 \\
\hline SSW & 0.002035 & 0.006533 & 0.012573 & 0.013861 & 0.011620 & 0.005850 & 0.000286 & 0.000079 \\
\hline SW & 0.004324 & 0.013050 & 0.026275 & 0.026371 & 0.016817 & 0.007312 & 0.000429 & 0.000064 \\
\hline WSW & 0.002480 & 0.006915 & 0.012033 & 0.008965 & 0.002416 & 0.000572 & 0.0 & 0.0 \\
\hline W & 0.004419 & 0.010380 & 0.012478 & 0.005198 & 0.000970 & 0.000223 & 0.0 & 0.0 \\
\hline WNW & 0.002464 & 0.005198 & 0.004085 & 0.001415 & 0.000302 & 0.000079 & 0.0 & 0.0 \\
\hline NW & 0.003799 & 0.007662 & 0.006215 & 0.002225 & 0.000668 & 0.000254 & 0.000016 & 0.000016 \\
\hline NNW & 0.002394 & 0.006994 & 0.007741 & 0.004292 & 0.001224 & 0.000684 & 0.000127 & 0.000095 \\
\hline $\mathrm{N}$ & 0.004657 & 0.013336 & 0.023494 & 0.017262 & 0.008393 & 0.004165 & 0.000509 & 0.000350 \\
\hline $\mathrm{NNE}$ & 0.004832 & 0.013018 & 0.023859 & 0.017676 & 0.007487 & 0.002813 & 0.000318 & 0.000143 \\
\hline $\mathrm{NE}$ & 0.007662 & 0.022715 & 0.037211 & 0.019663 & 0.006104 & 0.001749 & 0.000254 & 0.000175 \\
\hline ENE & 0.002066 & 0.007646 & 0.014576 & 0.013527 & 0.005214 & 0.001860 & 0.000302 & 0.000207 \\
\hline $\mathrm{E}$ & 0.002432 & 0.007010 & 0.015673 & 0.015291 & 0.007423 & 0.002893 & 0.000493 & 0.000064 \\
\hline ESE & 0.001446 & 0.003576 & 0.008250 & 0.007487 & 0.003259 & 0.001319 & 0.000318 & 0.000095 \\
\hline $\mathrm{SE}$ & 0.001701 & 0.004260 & 0.008250 & 0.007328 & 0.002686 & 0.000699 & 0.000048 & 0.000048 \\
\hline SSE & 0.000827 & 0.002925 & 0.004769 & 0.003116 & 0.001256 & 0.000334 & 0.000016 & 0.0 \\
\hline $\mathrm{S}$ & 0.001780 & 0.004276 & 0.007884 & 0.006152 & 0.002861 & 0.000779 & 0.000079 & 0.0 \\
\hline
\end{tabular}


Table D.3. Annual Average Stack Dilution Factors of Effective Area Perimeter

\begin{tabular}{llc}
\hline $\begin{array}{c}\text { Direction from } \\
\text { Stack }\end{array}$ & $\begin{array}{c}\text { Distance } \\
\text { (meters) }\end{array}$ & $\begin{array}{c}\text { Dilution Factor } \\
\left(\mu \mathrm{Ci} / \mathrm{m}^{3} \text { per } \mu \mathrm{Ci} / \mathrm{sec}\right)\end{array}$ \\
\hline N & 3465 & $1.08 \times 10^{-7}$ \\
NNE & 3925 & $9.30 \times 10^{-8}$ \\
NE & 3315 & $1.72 \times 10^{-7}$ \\
ENE & 3315 & $7.20 \times 10^{-8}$ \\
E & 3355 & $7.52 \times 10^{-8}$ \\
ESE & 3160 & $4.21 \times 10^{-8}$ \\
SE & 2780 & $4.76 \times 10^{-8}$ \\
SSE & 2935 & $2.47 \times 10^{-8}$ \\
S & 3505 & $3.62 \times 10^{-8}$ \\
SSW & 3580 & $5.62 \times 10^{-8}$ \\
SW & 3660 & $1.06 \times 10^{-7}$ \\
WSW & 3885 & $5.30 \times 10^{-8}$ \\
W & 4380 & $6.20 \times 10^{-8}$ \\
WNW & 3350 & $4.03 \times 10^{-8}$ \\
NW & 3085 & $6.26 \times 10^{-8}$ \\
NNW & 3050 & $5.38 \times 10^{-8}$ \\
\hline
\end{tabular}




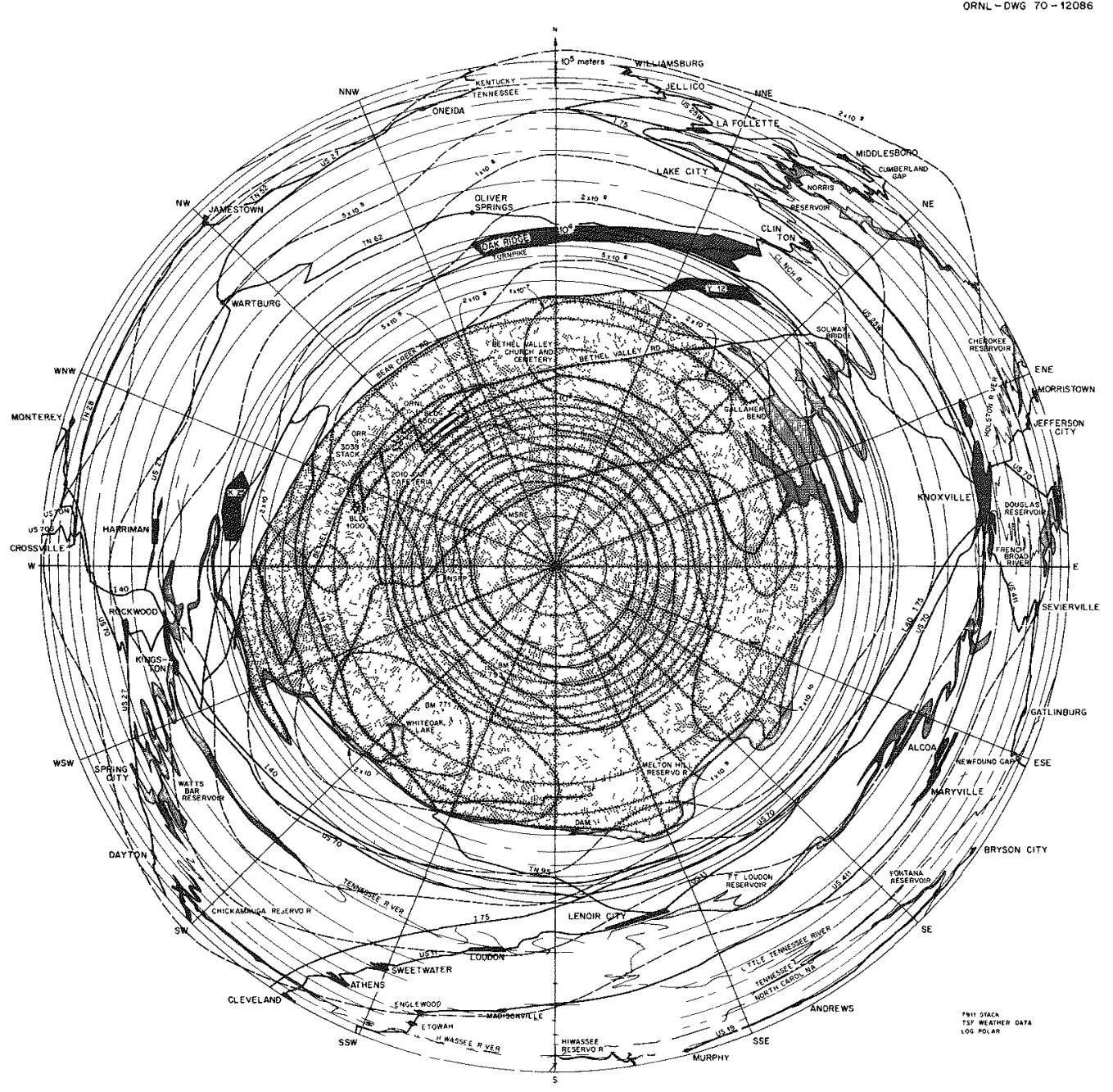

Fig. D.1. Log Polar Isopleths of Expected Annual Average Stack Dilution Factors for the Plant Site. 


\section{References}

1. F. Pasqui11, Meteorol. Mag., Vol. 90, p. 1063 (1961).

2. F. Gifford, Nuclear Safety, 4(2): 47 (1961).

3. D. H. Slade, editor, "Meteorology and Atomic Energy 1968," USAEC Report TID-24190, U.S. Atomic Energy Commission, latest printing August 1972 .

4. F. T. Binford, T. P. Hamrick, and Beth H. Cope, "Some Techniques for Estimating the Results of the Emission of Radioactive Effluent from ORNL Stacks," USAEC Report ORNL-TM-3187, Oak Ridge Nationa1 Laboratory, October 1970. 
Appendix E

ENGINEERING DRAWINGS

Drawing Number

F-11416-EP-001-E

F-11416-EM-001-D

F-11416-EM-007-D

W-11416-EM-008-D
Title

SOLEX Process for (ThU) $\mathrm{O}_{2}$ Microsphere Preparation, Pilot Plant Flow Sheet

Microsphere Coating Process, Pilot Plant Flow Sheet

Fue1 Rod Fabrication, In-Block Carbonization Flow Sheet

Fuel Element Assembly, In-Block Carbonization Flow Sheet 


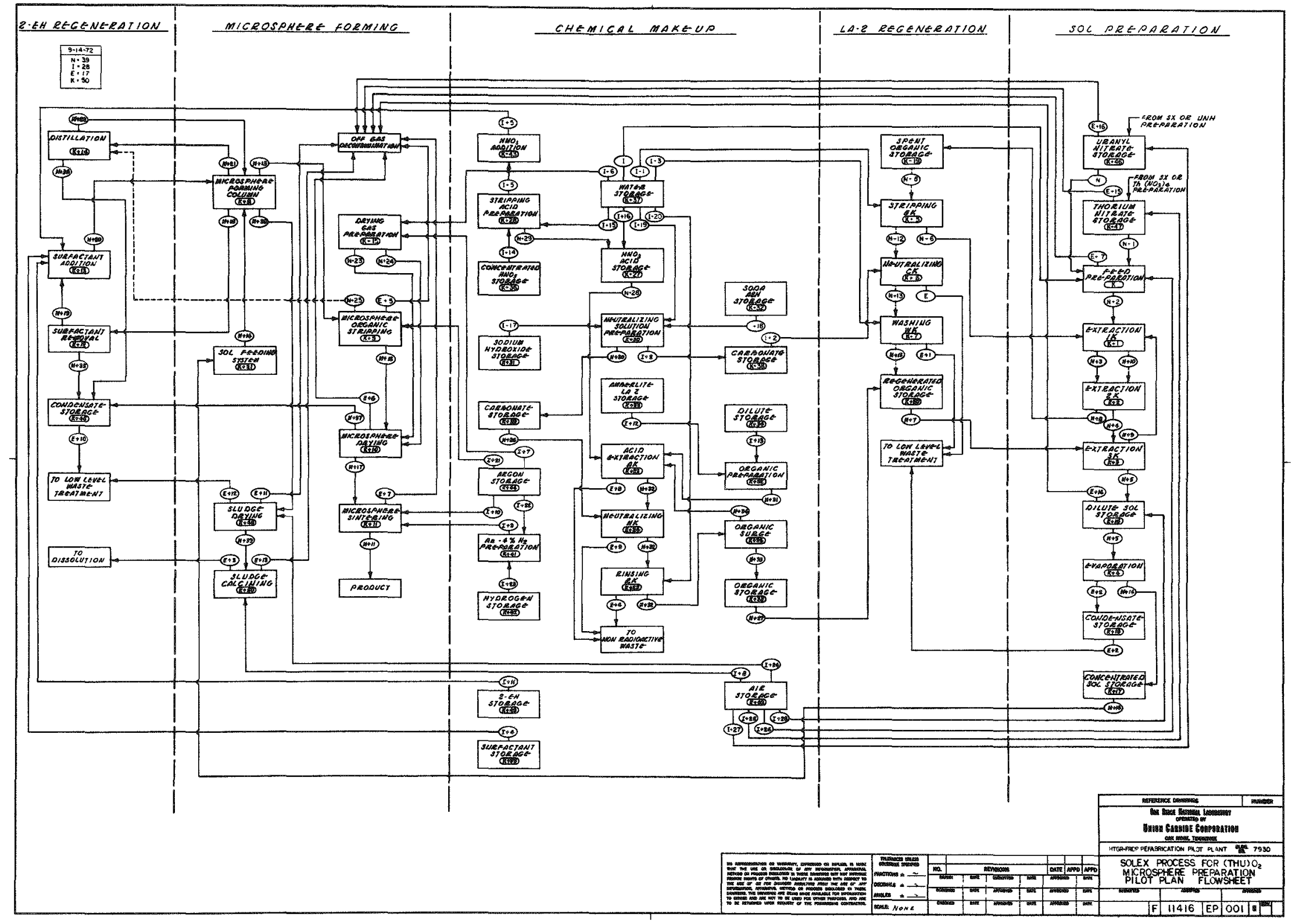





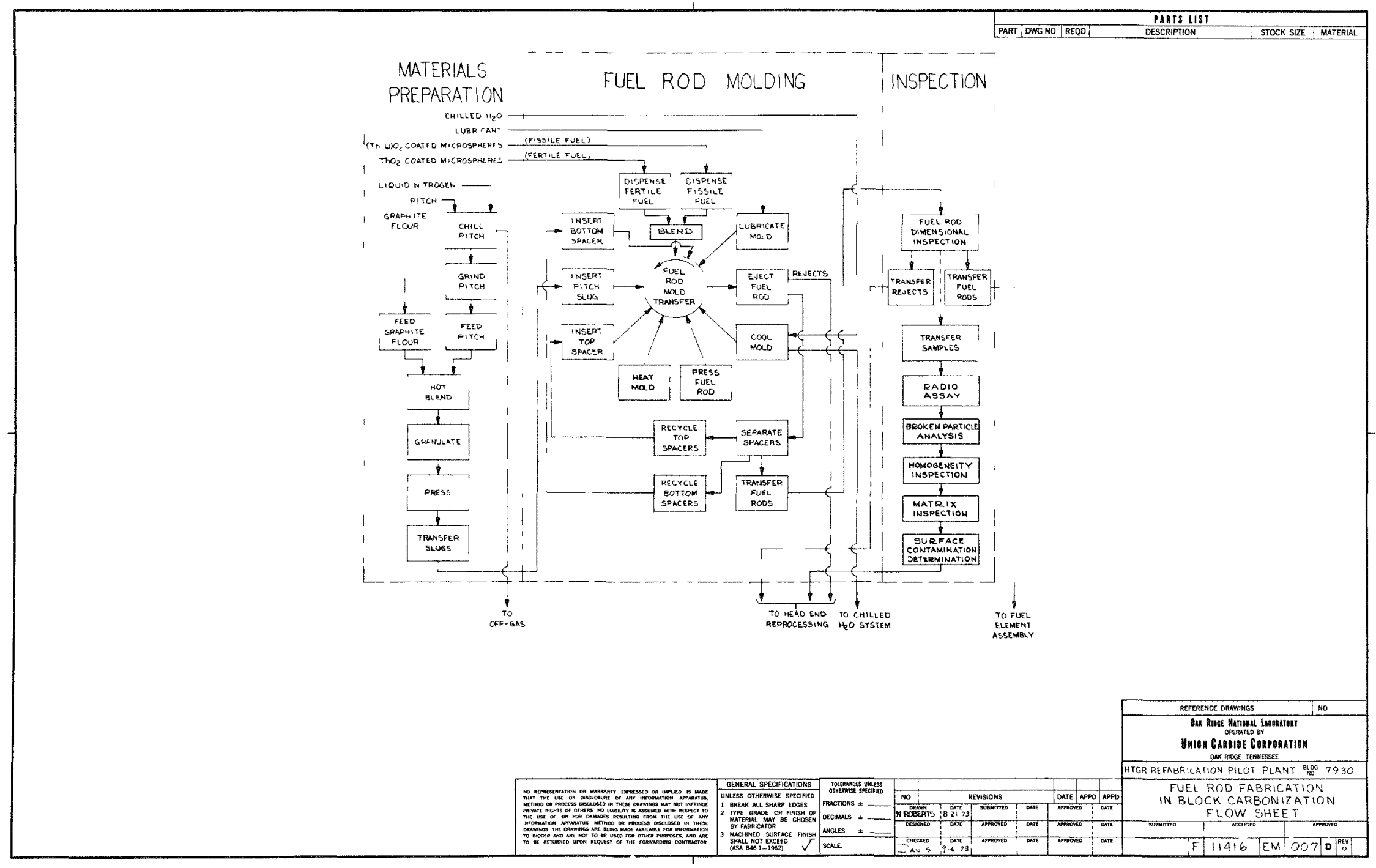




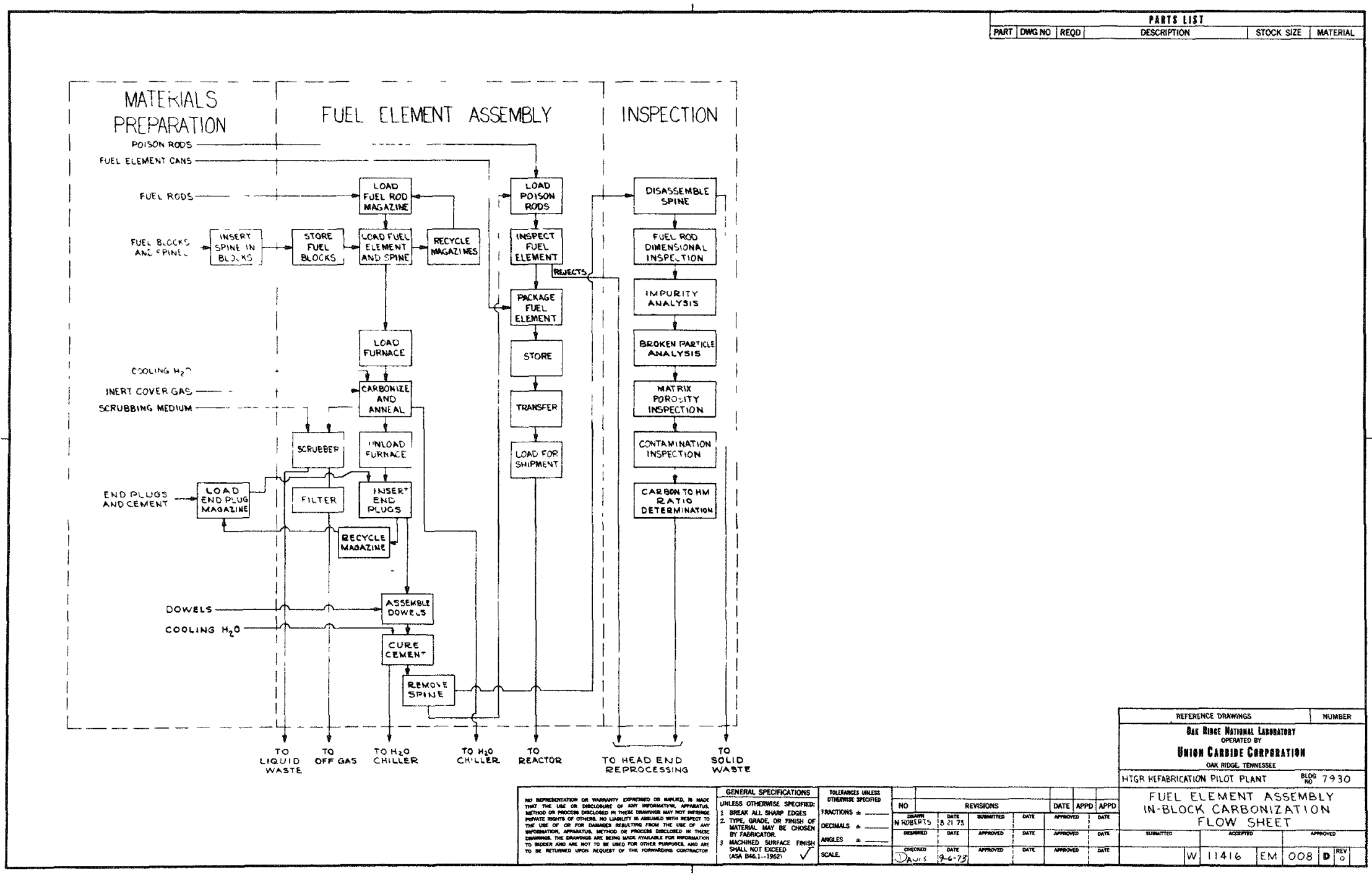




\author{
Appendix F \\ COMMENTS RECEIVED ON THE DRAFT ENVIRONMENTAL \\ STATEMENT AND AEC'S RESPONSE
}

The following letters were received by the $\mathrm{AEC}$ in response to a request for comments on the draft Environmental Statement (WASH-1533) for the HTGR Fue1 Refabrication Pilot Plant which was issued for comments in January 1974.

\title{
$\underline{\text { Agency }}$
}

$\underline{\text { Page }}$

Department of Agriculture, Agricultural Research Service

Department of Commerce

119

State of Tennessee

Department of Hea1th, Education, and Welfare 123

Department of Transportation

Department of the Interior

Department of Agriculture, Forest Service

Department of Agriculture, Soil Conservation Service

Environmental Protection Agency 


\section{UNITED STATES DEPARTMENT OF AGRICULTURE AGRICULTURAL RESEARCH SERVICE \\ WASHINGTON, D.C. 20250}

February 19, 1974

Mr. J. L. Liverman

Biomedical and Environmental

Research and Safety Programs

U.S. Atomic Energy Commission

Washington, D.C. 20545

Dear Mr. Liverman:

The Agricultural Research Service has received three

Atomic Energy Commission Draft Environmental Impact

Statements: WASH-1532; WASH-1533; and WASH-1534.

We have reviewed these and have no comments to make

at this time.

Sincerely,

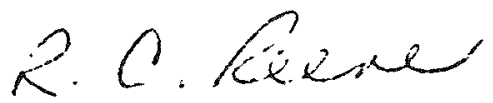

Ronald C. Reeve

Acting Assistant Administrator

National Program Staff 
UNITED STATES

ATOMIC ENERGY COMMISSION

WASHINGTON, D.C. 20545

AUG $16 \quad 1974$

Mr. Ronald C. Reeve

Acting Assistant Administrator

National Program Staff

U.S. Department of Agriculture

Washington, D.C. 20250

Dear Mr. Reeve:

Thank you for your letter of February 19, 1974 concerning your review of the Atomic Energy Comission's draft environmental statenent for the HTGR Fuel Refabrication Pilot Plant, Oak Ridge National Laboratory, Oak Ridge, Tennessee, and advising us that you have no comments. The statement has been revised in response to comments received from other reviewing organizations.

We appreciate your continued interest in our programs. Copies of the final statement are enclosed for your information.

Sincerely,

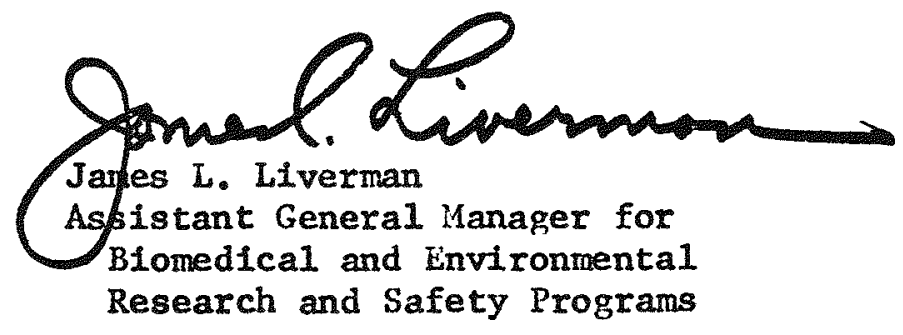

\section{Enclosure:}

Final linvironmental Statement for HTGR

Fuel kefabrication Pilot Plant, ORNL,

Oak Ridge, Tennessee (5 copies) 


\section{9}

OFFICE OF THE ASSISTAUT SECAETARY OF COMNE:CE Washington, D.C. 20230

March 19, 1974

Mr. James L. Liverman

Assistant General Manager

for Biomedical and Environmental

Research and Safety Programs

Atornic Energy Commission

Washington, ${ }_{3}$. C. 20545

Dear Mr. Liverman:

The draft environmental impact statement for WASH-1533 - HTGR Fuel Refabrication Pilot Plant, Oak Ridge National Laboratory, Tennessee, which accompanied your letter of February 5, 1974, has been reviewed and the following comments are offered for your consideration.

Since the effluent release from the proposed facility is through a common stack shared also by the High-Flux Is otope Reactor and the Transuranium Processing Plant, the assessment of the environmental impact should be on the sum of all three facility gaseous effluents. Only effluent releases from the proposed facility are listed.

There is a discrepancy in the height of the stack. Page 61 lists $75.8 \mathrm{~m}$ while Appendix D (p. 142) lists $80.8 \mathrm{~m}$.

Thank you for giving us an opportunity to provide these comments, which we hope will be of assistance to you. We would appreciate receiving a copy of the final statement.

\section{Since rely,}

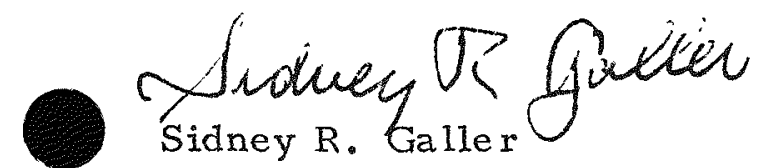

Deputy Assistant Secretary

for Environmental Affairs 


\author{
UNITED STATES \\ ATOMIC ENERGY COMMISSION \\ WASHINGTON, D.C. 20545
}

AUg 161974

Dr. Sidney R. Galler

Deputy Assistant Secretary

for Environmental Affairs

U. S. Department of Commerce

Washington, D. C. 20230

Dear Dr. Galler:

Thank you for your letter of March 19, 1974, which provided comments on the Atomic Energy Commission's draft environmental statement for the HTGR Fuel Refabrication Pilot Plant, Oak Ridge National Laboratory (ORNL), Oak Ridge, Tennessee. The statement has been revised in response to your comments and comments from other agencies.

With respect to your suggestion that we assess the environmental impact of gaseous effluents from other facilities where a common stack is used, the scope of this statement is limited to effluents from the subject fuel refabrication plant which contributes only a small percentage of the effluents. However, an assessment of the environmental impact of all the operations at the ORNL site is in preparation and will be completed by the end of this year. This assessment will cover all the waste management activities at the site including the gaseous effluents from the other operating facilities using the common stack.

We appreciate your continued interest in our programs. Copies of the final statement are enclosed for your information.

\title{
Sincerely,
}

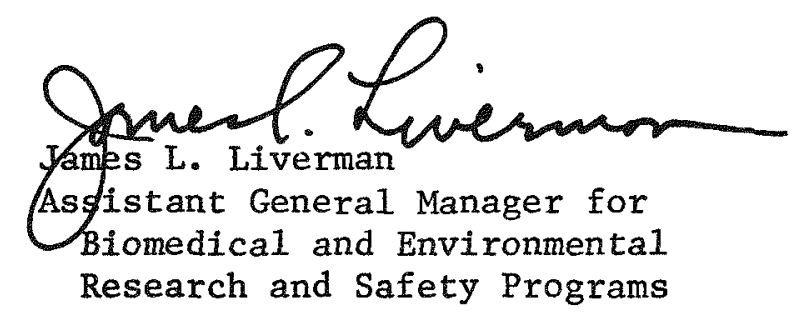

Enclosure:

Final Environmental Statement - HTGR

Fuel Refabrication Pilot Plant, ORNL,

Oak Ridge, Tennessee (WASH-1533)

( 4 copies) 


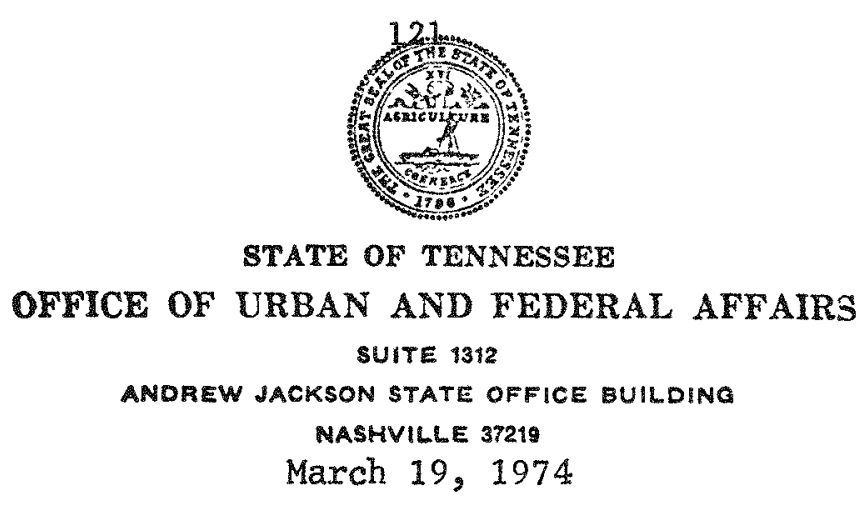

3.8.74.2714

Dincton

Mr. James L. Liverman

Assistant General Manager for

Blomedical \& Environmental Research

and Safety Programs

United States Atomic Energy Commission

Washington, D. C. 20545

Re: Draft Environmental Statements

1. Radioactive Waste Facilities (WASH-1532

2. HTGR Fuel Refabrication Pilot Plant (WASH-1533)

Dear Mr. Liverman:

In conformance with guideline procedures stipulated in OMB Circular A-95 and in conformance with the Governor's Executive Order 6, designating the Office of Urban and Federal Affairs as the State Clearinghouse for Federal grant programs, we have reviewed your draft environmental statements for the above mentioned proposed projects at the Oak Ridge National Laboratory.

Our evaluation of submitted materials identified no conflicts with existing or planned state activities. Therefore, we deem the proposal acceptable on the basis of information made available to us at this time. If our office, as the State Clearinghouse, can be of further assistance, please do not hesitate to contact us.

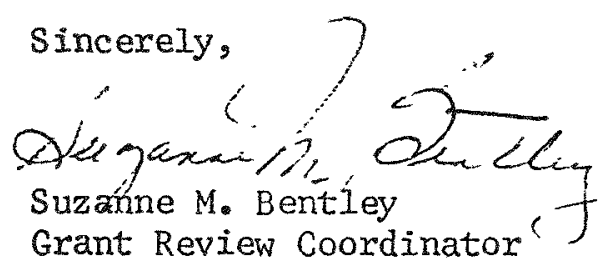

$\mathrm{SMB} / \mathrm{prp}$ 


\section{UNITED STATES}

ATOMIC ENERGY COMMISSION

WASHINGTON, D.C. 20545

\section{AUG 161974}

Honorable Winfield Dunn

Governor of Tennessee

Nashville, Tennessee 37219

Dear Governor Dunn:

Thank you for the letter of March 19, 1974 from the Office of Urban and Federal Affairs, State of Tennessee, concerning your review and comments on the Atomic Energy Commission's draft environmental statement for the HTGR Fuel Refabrication Pilot Plant, Oak Ridge National Laboratory, Oak Ridge, Tennessee. The statement has been revised in response to comments received from the reviewing organizations.

We appreciate your continued interest in our programs. A copy of the final statement is enclosed for your information.

\section{Sincere $1 \mathrm{y}$,}

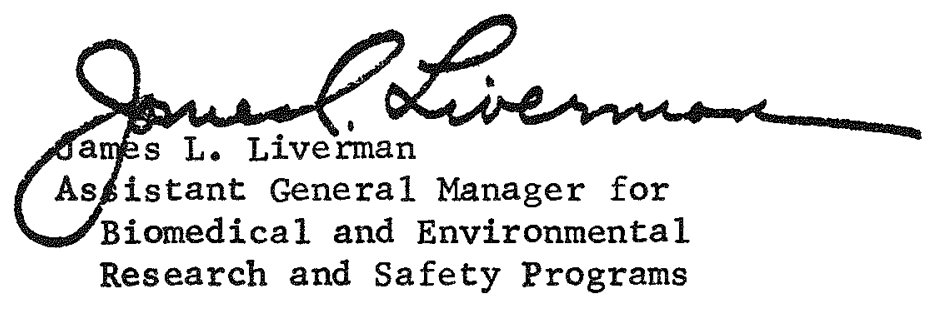

Enclosure:

Final Environmental statement for HTGR

Fuel Refabrication Pilot Plant, ORNL,

Oak Ridge, Tennessee ( 1 copy)

cc: Tilden J. Curry, Exec. Dir, , State Planning Office, w/encl。( 1 copy)

Suzanne M. Bentley, Grant Review

Coordinator, Office of Urban and

Federal Affairs, State of Tennessee,

w/enc1. ( 1 copy) 


\author{
DEPARTMENT OF HEALTH, EDUCATION, AND WELFARE \\ OFFICE OF THE SECRETARY \\ WASHINGTON, D C. 20201
}

\title{
MAR 221974
}

IIr. James I. Iivcriman

issistant Goneral "anager

for Biorndical and invirommental

Research and safet? Programs

Atomic Inergy Comission

Washington, D. C. 20545

iear ir. Liverman:

Thank you for your lettor of Eomuary 5 reruesting coments on the araft invironmental Imbact Statoment for kefaiorication Pilot Plant, Oak ridge -iational La'oratory, Iennessee. Based on the revier by acpromriate program agencios and regional offices, we nave cetormines tiat the prowosed construction, oneration and decomissioning of tie Ims? Iuel refaimication Pilot plant vould be expected to have a uirimal impact on the enviromront. $A 11$ effluents from tie pronosed projoct :ijll be controlled releases through cxisting waste disposal systams. rine construction of tile facilit? ijill in fact require only randification of alreacy constructed facjilities.

Unavoidable racioactivity releases to tie enviroment rill caure a maximm potantial individual exposure of $3.6 \times 10^{-3}$ rillirons per year froin gaseous effluents. rise concentration of radioactivity in tie lirquid effluents vill be 100 milliontl of the concentration guicio and the resultant exposure to poculations will be negliqible.

The result of accidents lave been analyzed in the reoort. The major impact from radiation pould ve the result of a firc. Tie maxinu? personnel dose dorn-wind in tise case of a maximu credible accicent of this type voula be less than 200 millirem to any indiviciual and no isolation of land area outsire the controlled access area rould be required. The consecmonces of explosions or criticality accicents vould be less. insposures resulting from tie transportation of natorials to and from the pilot plant would aproar to be insignificant and provajy unmeasurawle.

Thank you for the opportumity to comment on this statoment.

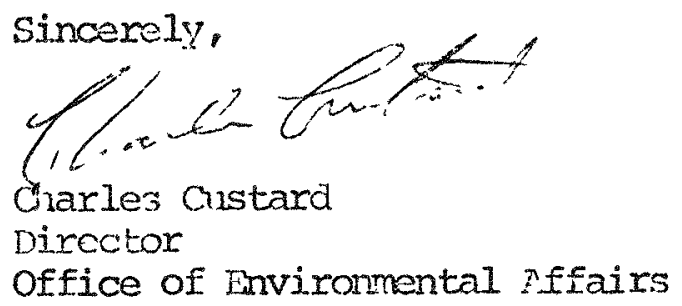




\section{UNITED STATES \\ ATOMIC ENERGY COMMISSION \\ WASHINGTON, D.C. 20545}

AUG 161974

Mx. Charles Custard, Director

Office of Environmental Affairs

U.S. Department of Health, Education, and Welfare

Washington, D.C. 20201

Dear Mr. Custard:

Thank you for your letter of March 22, 1974 concerning your review and comments on the Atomic Energy Commission's draft environmental statement for the HTGR Fuel Refabrication Pilot Plant, Oak Ridge National Laboratory, Oak Ridge, Iennessee. The statement has been revised in response to coments recelved from the reviewing organizations.

We appreciate your continued interest in our programs. Coples of the final statement are enclosed for your information.

sincerely,

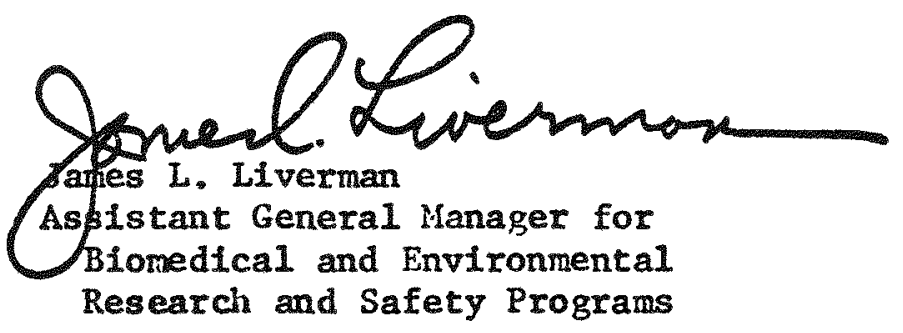

Enclosure:

FInal Environmental statement for HTGR

Fuel Refabrication Pilot Plant, ORNL,

Oak Ridge, Tennessee ( 3 copies) 


\section{DEPARTMENT OF TRANSPORTATION UNTTED STATES COAST GUARD}

MAILING ADDRESS:

U.S. COAST GUARD (G-WS/73)

400 SEVENTH STREET SW.

WASHINGTON. D.C. 20590

PHONE: (202) 426-2262

- 95 m 1974

Mr. James L. Liverman

Assistant General Manager for

Biomedical and Environmental

Research and Safety Programs

Atomic Energy Commission

Washington, D. C. 20545

Dear Mr. Liverman:

This is in response to your letter of 5 February 1974 addressed to

Mr. Martin Convisser concerning the draft environmental impact statement for the HTGR Fuel Refabrication Pilot Plant, Oak Ridge, Anderson County, Tennessee.

The concerned operating administrations and staff of the Department of Transportation have reviewed this draft statement. We have no comments to offer nor do we have any objection to this draft statement.

The opportunity to review this draft statement is appreciated.

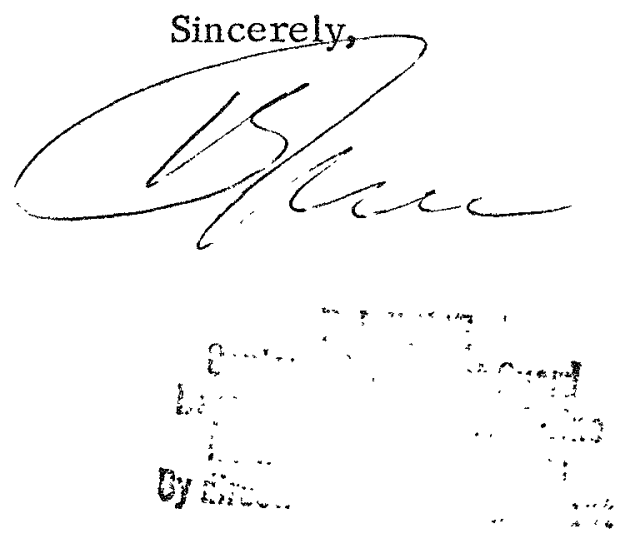




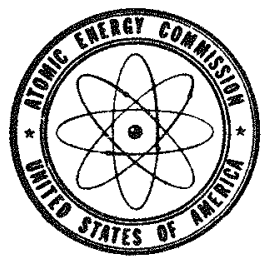

\section{UNITED STATES \\ ATOMIC ENERGY COMMISSION \\ WASHINGTON, D.C. 20545 \\ AUG 161974}

Captain R. I. Price

Deputy Chief

Office of Marine Environment

and Systems

U.S. Coast Guard

400 Seventh Street, SW.

Washington, D.C. 20590

Dear Captain Price;

Thank you for your letter of March 25, 1974 concerning your review of the Atomic Energy Commission's draft environmental statement for the HTGR Fuel Refabrication Pilot Plant, Oak Ridge National Laboratory, Oak Ridge, Tennessee, and advising us that you have no comments. The statement has been revised in response to comments received from other reviewing organizations.

We appreciate your continued interest in our programs. A copy of the final statement is enclosed for your information.

$$
\text { Sincerely, }
$$

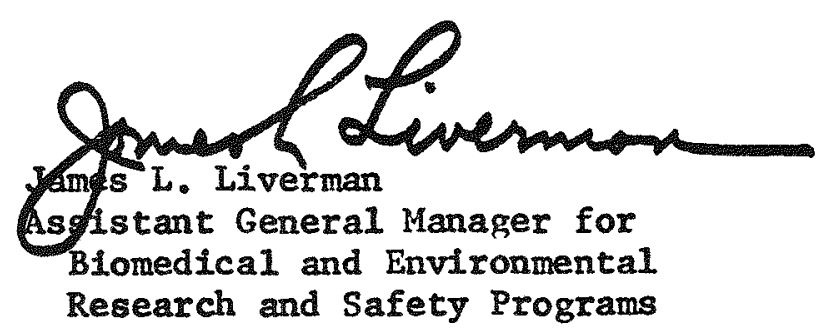

Enclosure:

Final Environmental statement for HTGR

Fuel Refabrication Pilot Plant, ORRL,

Oak Ridge, Tennessee 


\title{
United States Department of the Interior
}

\author{
OFFICE OF THE SECRETARY \\ WASHINGTON, D.G. 20240
}

In reply refer to:

PEP ER 74/179

APR 1974

Dear Mr. Liverman:

Thank you for your letter of February 5, 1974, transmitting copies of the AEC's draft environmental statement dated January 1974, on the HTGR Fuel Refabrication Pilot Plant, Oak Ridge National Laboratory, Roane County, Tennessee.

Our comments are presented according to the format of the statement or according to subject.

General

We recommend that a comprehensive impact statement be prepared for the oak Ridge National Laboratory site as we note that WASH-1532, ER 74/180, entitled Radioactive Waste Facilities, Oak Ridge National Laboratory is also currently under review in the Department, and the effluents produced by the HTGR refabrication facility are to be processed in the referenced waste facility. We suggest that evaluation of separate units can sometime allow pertinent aspects of the total system to escape evaluation as noted in Effluents and Solid Wastes, below.

We also recommend that all comments in this statement be correlated with WASH-1532, ER 74/180.

\section{Fuel Element Shipment}

Safe operation of high-temperature, gas-cooled reactors is dependent upon the integrity of the graphite coating on the uranium-thorium microspheres. Thus, moisture must not be allowed to contact this coating during storage or transfer. While we assume moisture in the storage areas and in the shipping container will be monitored, a statement to this effect in the final statement is suggested.
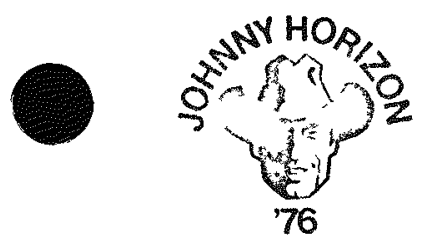
Effluents and Solid Wastes

Storage tanks to be used for the liquid radioactive wastes from the plant have been referred to briefly. For example, it is estimated on page 29 that about 1,000 gallons of such wastes would be stored in existing TURF waste tanks following the decommissioning of the plant. Another draft statement WASH-1532 shows on page 23 that 760,000 gallons of such wastes would be produced annually by operation of the Pilot Plant, and that storage would initially be in stainless steel tanks. However, neither draft statement provides a description of the storage tanks, on whether they are doubly contained, or whether they are equipped with adequate monitoring devices to detect leakage of radioactive liquids. It seems essential to include a discussion of the design and safeguards for these tanks in the final statement.

The only reference to storage of liquid radioactive wastes from the plant appears to be in conrection with the 1,000 gallons of wastes resulting from decommissioning, as referred to above, and this relatively small quantity of liquid would have a level of activity of less than 4 curies per gallon. With regard to liquid wastes expected to be generated by normal operation of the plant, however, it is stated on page 68 only that "all known radioactive wastes are pumped directly . . to the ORNL Intermediate-Level vaste Collection and Treatment system." It is also stated on the same page that "the liquids are made basic and piped into a 600gallon-per-hour waste evaporator." These statements give no suggestion that the wastes would not be promptly processed by the evaporator, nor is lengthy storage of the wastes mentioned anywhere in the environmental statement. It is only by reference to another environmental statement, WASH-1532, that information on this can be obtained, indicating that Pilot Plant liquid wastes would be allowed to decay for at least 5 years, even before being processed by the evaporator. We recommend that the final statement should discuss any potential environmental impacts of storage of the liquid wastes for more than 5 years, and clarify the planned ultimate disposition of the wastes.

Although the statement provides a comprehensive description in Table 6 of radionuclides anticipated in the radioactive liquid wastes, the concentrations shown are in the greatly diluted effluent. The original concentrations would evidently be higher by a factor of $5 \times 1018$. Using the factors given on page 70 , it appears that the liquid must originally have 
a concentration equivalent to about 2.6 curies per gallon of uranium-232 and 4.2 curies per gallon of uranium-233. The total activity of the liquid waste at the time of final processing prior to discharge would evidently be in the vicinity of 20 curies per gallon. If these estimates are correct based on incomplete information in the statement, each gallon of the liquid waste would contain about twice the radioactivity of a cask containing three completed fuel elements for offsite shipment. In addition, information in the other environmental statement previously referenced, WASH-1532, page 22 , suggests that this level of activity is present after at least 5 years of decay and at an unspecified amount of dilution. Both environmental statements should provide an unequivocal estimate of the radioactivity of the waste as it is initially stored, and of the total radionuclide content at that time. For example, no mention has been made of its content of cesium-137, strontium-90, or cerium-144. In addition, the toxic longevities of the various waste components should be specified.

With regard to the analysis of potential accidents, no consideration appears to have been given to the possibility of leakage of the liquid waste from its storage tanks. Since leakage of Pilot Plant waste was not discussed in the environmental statement for Radioactive Waste Facilities, WASH-1532, we feel that the present statement should discuss the environmental consequences of tank leakage and adequacy of monitoring devices and other safeguards.

Need for Project

Justification of the project on the basis of a lack of experience with remote fabrication of these fuel elements is presented. This justification is unclear because of the statement on page 19 that says the Fort St. Vrain Reactor, which uses the same type of fuel element, is currently nearing commercial operation. Thus, the justification does not appear to be adequately substantiated.

To support the need for the pilot plant, the statement on page 41 might better read, "There presently is no experience relative to the remote refabrication of HTGR fuels on any scale. Further, except for production of minor quantities of fuel for the Fort St. Vrain Reactor, there is no experience in remote fabrication of these fuels." 
$\underline{\text { Seismology }}$

In regard to seismic risk, it is stated on page 55 that "the TURF site is in an area.. assigned a zone -2 risk, indicating a potential for moderate damage." The only specific mention of ground accelerations considered in design of the plant is the statement on page 119 that "within a 100-year period there exists a $50 \%$ probability for ground motion acceleration to exceed 0.03 to $0.09 \mathrm{~g} . "$ However, the actual ground accelerations used as a basis for design of the plant have not been identified. Although it seems evident that the design of the thick-walled hot cells is more than adequate, it would be advisable to include a discussion of seismic design because highly radioactive material will not be confined entirely to the cells. It is noted on pages 33 and 73 that each shipment of three completed fuel elements would contain total radioactivity of about 10 curies, and would be protected by a 23-ton cask. However, it seems evident that a single gallon of liquid waste from the plant would contain considerably more than 10 curies of activity, yet no information has been provided on the adequacy of the facilities to contain this liquid in the event of seismic activity. The seismic design criteria applied to all structures that would be used for fabrication of HTGR fuel elements and for containment of the resulting radioactive wastes should be evaluated in the final statement, and any significant differences in these criteria for the various structures should be explained.

Land Use

We understand that at a previous date, the AEC transferred about 800 acres of former Reservation lands bordering the Clinch River to the City of Oak Ridge for future development as a regional park and that, to date, no development has taken place because of lack of funds.

We note that brief mention is made of a recent proposal, ". . that the Oak Ridge Reservation be designated an Environmental Study Park." The information presented is limited, and a considered judgment cannot be made regarding the matter of best potential land use. Thus, we suggest that the final statement present and assess all environmental and related aspects of the Environmental Study Park proposal. 
5

We hope these comments will be helpful to you in the preparation of a final statement.

\section{Sincerely yours,}

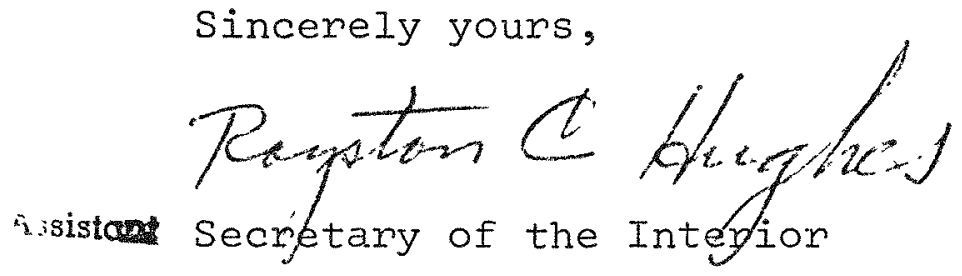

Mr. James L. Liverman

Assistant General Manager

For Biomedical and Environmental

Research and Safety Programs

Atomic Energy Commission

Washington, D. C. 20545 
Mr. Royston C. Hughes

Assistant Secretary of the Interior

U.S. Department of the Interior

Washington, D.C. 20240

Dear Mr. Hughes:

Thank you for your letter of Apri1 1, 1974 which provided comments on the Atomic Energy Commission's draft environmental statement for the HTGR Fuel Refabrication Pilot Plant, Oak Ridge National Laboratory (ORNL), Oak Ridge, Tennessee. The statement has been revised in response to your comments and comments from other agencies.

With respect to your recommendation that a comprehensive impact statement be prepared for the ORNL site, an environmental assessment of the impact of a 11 operations at the ORNL site is in preparation and will be completed by the end of this year. The assessment will cover the waste management activities including radioactive effluents from other operating facilities. The radioactive effluent contribution of the subject fuel refabrication pilot plant represents only a sma 11 percentage of the tota1. The enclosed staff response covers other specific concerns which you raised.

We appreciate your continued interest in our programs. Copies of the final statement are enclosed for your information.

sincerely,

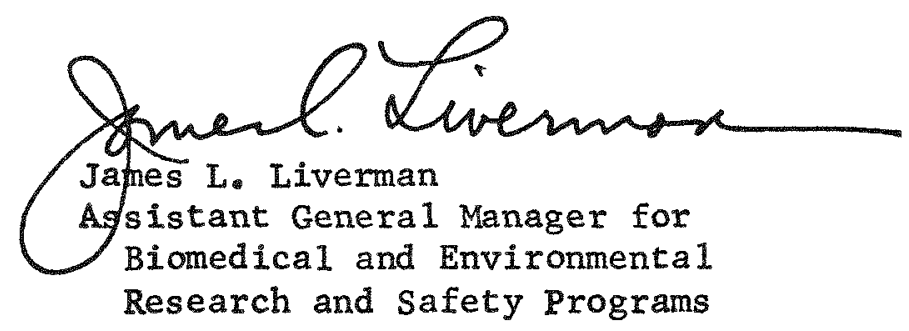

Enclosures:

1. Staff Response to Interior Comments

2. Fina1 Environmental Statement - HTGR

Fuel Refabrication Pilot Plant, ORNL, oak Ridge, Tennessee (WASH-1533)

(7 copies) 


\section{ENCLOSURE 1 \\ STAFF RESPONSE TO COMMENTS FROM THE \\ DEPARTMENT OF THE INTERIOR}

Fue1 Element Shipment

Atmospheric moisture has no detrimental effect on the pyrolytic carbon coating of fuel microspheres. The dense pyrolytic carbon coating is impermeable to and nonreactive with atmospheric moisture. The assembled graphite fuel element will not be adversely affected by atmospheric moisture expected to be encountered in storage or shipping.

Effluents and Solid Wastes

The final statement has been revised to include a description of the TURF waste tanks for collecting the liquid radioactive wastes prior to transferring them to the ORNL Intermediate-Leve1 Waste Collection and Treatment system.

It should be noted, however, that the 760,000 gallons per year of Pilot Plant Wastes referred to in the comments from the Department of the Interior are for the operation of several pilot plants postulated in WASH-1532 (Environmental Statement, Radioactive Waste Facilities, Oak Ridge Nationa1 Laboratory), not for the HTGR Fuel Refabrication Pilot Plant. The quantities and radionuclide contents of the liquid radioactive effluents expected from the HTGR Fuel Refabrication Pilot Plant are as was indicated in WASH-1533. They will be processed by the evaporator of the ORNL Intermediate-Leve1 Waste Collection and Treatment System without lengthy holdup.

The liquid radioactive wastes from the HTGR Fuel Refabrication Pilot Plant wil1 contain about 0.00012 curies per gallon. These wastes will be concentrated by evaporation in the ORNL Intermediate-Leve 1 Waste Collection and Treatment System. About $2 \times 10^{-6}$ of the radioactivity in the liquid effluents from the HTGR Fuel Refabrication Pilot Plant will be released to the environment in the condensate from the evaporators. The concentration of radionuclides at the point of release from the ORNL site, considered to be White Oak Dam, resulting from the operation of the HTGR Fuel Refabrication Pilot Plant can best be determined by applying the decontamination factor for the evaporator and the dilution factor for White Oak Creek to the expected annual release rate for each radionuclide. The concentrations determined in this manner are given in table 8 of WASH - 1533. 
Need for Project

The initial fuel for the Fort St. Vrain Reactor will contain ${ }^{235} \mathrm{U}$ and thorium, which was fabricated by contact means in an unshielded facility. on $1 y$ the recycle fue 1 , which contains ${ }^{23} 3_{\mathrm{U}}$ or recycle ${ }^{235} \mathrm{U}$ requires remote fabrication. At present there is no experience in the remote fabrication of HTGR fuels.

$\underline{\text { Seismology }}$

The final statement has been revised to incorporate information on the seismic design criteria for the facility (TURF). It should be noted, however, that the liquid effluents from the HTGR Fuel Refabrication Pilot Plant will contain about 0.00012 curies per gallon. The ten curies per gallon mentioned in the comments from the Department of the Interior were apprent1y determined from the data given in WASH-1532, "Radioactive Waste Facilities, Oak Ridge National Laboratory," for "future pilot plants," which is not relevant to the HTGR Fue1 Refabrica. tion Pilot Plant.

Land Use

The final statement has been revised to indicate that the HTGR Fuel Refabrication Pilot Plant will have no influence on the proposed designation of the Oak Ridge Reservation as the Environmental Study Park. 
United States Department of Agriculture

FOREST SERVICE

Southeastern Area, State and Private Foresiry

Ailante, Gecrgia 30300

$r_{\text {Mr. James L. Liverman }}$

Assistant General Manager

Biomedical \& Environmental Research and Safety Programs

AEC, Oak Ridge National Laboratory

Lak Ridge, Tennessee 37830

Dear Mr. Liverman:

Here are Southeastern Area, State and Private Forestry comments on the draft environmental statement covering the HTGR Fuel Refabrication Pilot Plant at Oak Ridge National Laboratory.

We see no environmental conflict in conducting needed fuel refabrication research on a short-term, pilot basis within the ORNI reservation. We commend your delineation of 41 areas within the reservation for the study of unique or important environmental problems.

Please keep us fully informed of study areas established in forested sections of the reservation and let us know if we can be of assistance in the design of such studies.

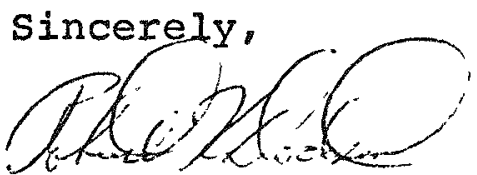

FREDERICK W. HONING

Area Environmental Coordinator 


\section{UNITED STATES \\ ATOMIC ENERGY COMMISSION \\ WASHINGTON, D.C. 20545}

AUG $1: 1979$

Mr. Frederick W. Honing

Area Environmental Coordinator

Forest Service

U.S. Department of Agriculture

Atlanta, Georgia 30309

Dear Mr. Honing:

Thank you for your letter of Apri1 2, 1974 concerning your review and comnents on the Atomic Energy Comission's draft environmental statement for the HTGR Fuel Refabrication Pilot Plant, Oak Ridge National Laboratory, Oak Ridge, Tennessee. The statement has been revised in response to coments recelved from the reviewing organizations.

We appreciate your continued interest in our programs. Copies of the inal statement are enclosed for your information.

sincerely,

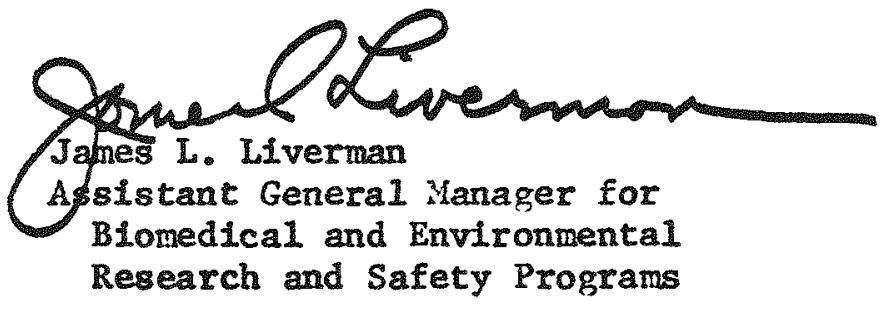

Enclosure:

Final Environmental Statement for HTGR

Fuel Refabrication P1lot Plant, ORNL,

Oak Ridge, Tennessee (5 copies) 


\section{UNITED STATES DEPARTMENT OF AGRICULTURE} SOIL CONSERVATION SERVICE

561 U. S. Courthouse, Nashville, Tennessee 37203

April 2, 1974

Mr. James L. Liverman

Assistant General Manager

Biomedical and Environmental Research and Safety Programs

Oak Ridge National Laboratory

Oak Ridge, Tennessee

Dear Mr. Liverman:

Subject: Draft Environmental Statement, HTGR Fuel Refabrication Pilot Plant and Radioactive Waste Facilities, Oak Ridge National Laboratory, Oake Ridge, Tennessee

Reference is made to the draft environmental statement for subject HTGR Fuel Refabrication Pilot Plant and Radioactive Waste Facilities, Oak Ridge National Laboratory, Oak Ridge, Tennessee which was referred to the Soil Conservation Service for review and comment.

The proposed project will not conflict with any present or proposed programs of this agency.

The primary concern of this agency is with adequate control of erosion and sedimentation during and after construction of a project. Since this project involves an insignificant amount of soil disturbance, soil erosion and sedimentation does not appear to be an environmental problem.

We appreciate the opportunity to review and comment on this draft environmental statement.

Sincerely,

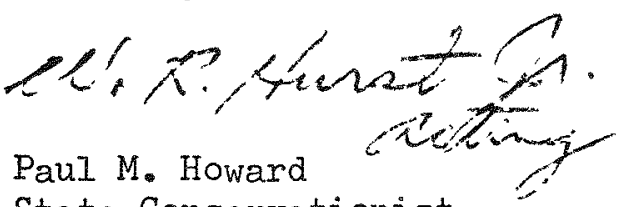

State Conservationist

cc: Kenneth E. Grant, Administrator Soil Conservation Service Washington, D. C.

Council on Environmental Quality 722 Jackson Place, N. W. Washington, D. C. 20006 Attention: General Counsel

Office of the Coordinator of Environmental

Quality Activities

Office of Secretary, USDA

Washington, D. C. 20250 


\section{UNITED STATES \\ ATOMIC ENERGY COMMISSION \\ WASHINGTON, D.C. 20545}

AUG 161974

Mr. Paul M. Howard

State Conservationist

Soil Conservation Service

U.S. Department of

Agriculture

561 U.S. Courthouse

Nashville, Tennessee 37203

Dear Mr. Howard:

Thank you for your letter of April 2, 1974 concerning your review and comments on the Atomic Energy Combission's draft environmental statement for the HTGR Fuel Refabrication Pilot Plant, Oak Ridge National Laboratory, Oak Ridge, Tennessee. The statement has been revised in response to coments received from the reviewing organizations.

We appreciate your continued interest in our programs. Coples of the final statement are enclosed for your information.

Sincerely.

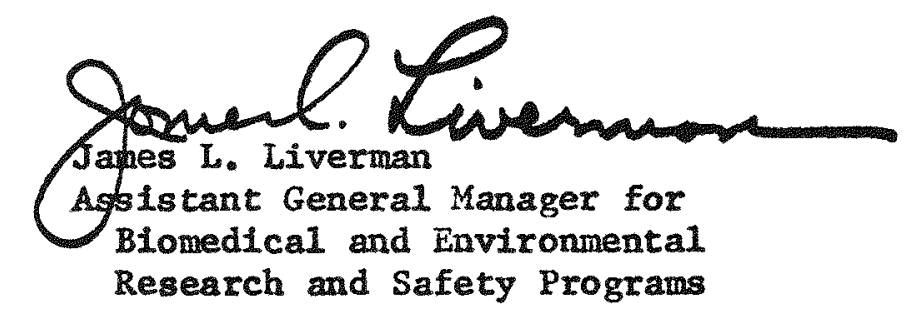

Enclosure:

Final Environmenta1 Statement for HTGR

Fuel Refabrication Pilot Plant, ORNL, Oak Ridge, Tennessee (5 coples) 


\section{UNITED STATES ENVIRONMENTAL PROTECTION AGENCY}

WASHINGTON, D.C. 20460

\section{$10 \sin 1974$}

Dr. James A. Liverman

Assistant General Manager

for Biomedical and Environmental Research

and Safety Programs

U.S. Atomic Energy Commission

Washington, D.C. 20545

Dear Dr. Liverman:

The Environmental Protection Agency has reviewed the draft environmental statement for the HTGR Fuel Refrabrication Pilot Plant-Oak Ridge National Laboratory, Oak Ridge,

Tennessee, issued on February 6, 1974. Our detailed comments are enclosed.

In our opinion, in order to provide a more complete and useful analysis of this facility, the following three additional subjects should be included in the final statement:

1. An analysis of the consequences of the discharge and dispersal of long-lived radionuclides into the general environment. The recently published EPA report entitled "Environmental Radiation Dose Commitment: An Application to the Nuclear Power Industry," presents general concepts for calculating the cumulative consequences of the release of long-lived radionuclides to the environment.

2. An evaluation of the amount of increased radiation exposure due to inhalation since the gaseous effluents from this facility are to be combined with those from two other facilities on the Oak Ridge site and released through a common stack. 
3. A discussion of the alternative of storing the fabricated fuel at ORNL rather than shipping the assemblies to the NRTS in Idaho as presently planned.

In light of the above and in accordance with EPA procedure, we have classified the project as ER (Environmental Reservations) and rated the draft statement as Category 2 (Insufficient Information). If you or your staff have any questions concerning our classification or comments, please don't hesitate to call on us.

sincerely,

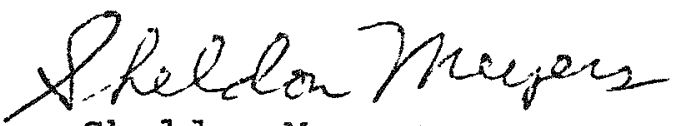

Sheldon Meyers

Director

Office of Federal Activities

Enclosure 
ENVIRONMENTAI PROTECTION AGENCY

WASHINGTON, D.C. 20460

APRIL 1974

ENVIRONMENTAI IMPÄCT STATEMENT COMMENTS

HTGR Fuel Refabrication Pilot Plant

TABLE OF CONTENTS

\section{PAGES}

INTRODUCTION AND CONCLUSIONS

1

RADIOLOGICAI ASPECTS

2

Radiation Exposure

Air Cleaning

Decommissioning

Accidents

Transportation

NON-RADIOLOGICAL ASPECTS

Biological

Chemical 
The Environmental Protection Agency has reviewed the draft statement for the HTGR Fuel Refabrication Pilot Plant-Oak Ridge National Laboratory, Oak Ridge, Tennessee, prepared by the Atomic Energy Commission (AEC) and issued on Eebruary 6, 1974. Following are our major conclusions:

1. The final statement should include an analysis of the consequences of the discharge and dispersal of long-lived radionuclides into the general environment. The recently published EPA report entitled "Environmental Radiation Dose Comitment: An Application to the Nuclear Power Industry," presents general concepts for calculating the cumulative consequences of the release of long-lived radionuclides to the environment.

2. The radioactive discharges from this plant are mixed in a common stack with the discharge from two other facilities. The amount of increase in radiation exposure due to the additional inhaled radioactivity from this facility should be discussed in the final statement.

3. The alternative of storing the fabricated fuel at ORNL rather than shipping the assemblies to the NRTS in Idaho was not discussed in the draft statement. We believe this alternative should be discussed in the final statement. 
RADIOLOGICAL ASPECIS

Radiation Exposure

The draft statement indicates that the gaseous effluents from the HTGR Fuel Refabrication Pilot Plant are to be released to the atmosphere through the 250 ft. High Flux Isotopes Reactor (HFIR) stack. The radioactive discharges from this plant and their relationship to the overall radiation levels in the area due to the combined releases from all site plants should be discussed in the final statement. The expected increase in radiation exposure due to inhaled radioactivity should be included in this discussion.

The final statement should also include an analysis of the consequences of the discharge and dispersal of longlived radionuclides into the general environment. By virtue of the long persistence of these materals their consequences may extend over many generations and, in this respect, these discharges can represent irreversible public health commitments. The recently published "Environmental Radiation Dose Comitment: An Application to the Nuclear Power Industry" (EPA-520/4-73-002) presents general concepts for calculating the cumulative consequences of the release of long-lived radionuclides to the environment. In our opinion, such cumulative consequences should be added to other environmental costs in the cost-benefit anaysis.

Air Cleaning

The methods of air cleaning for the process cell exhaust are described as being, "...four HEPA (high-efficiency particulate air) filters in series...", on page $34 ;$ and "...five parallel compartments, each of which contains six HEPA Iilters," on page 36. The final statement should clarify the discussion of the HEPA filter system.

Decommissioning

Decommissioning is not discussed in any detail in the draft statement. The final statement should include the added environmental costs of decommissioning the facility. These costs should include descriptions and quantities of wastes in the form of solids or air and water-borne releases. 
Acciaents

In the discussion of possible accidents within the facility, the radiation dose from releases during a fire (page 78) indicates the personnel dose downwind would be less than $200 \mathrm{mrem}$. This discussion should be expanded in the final statement to indicate the radiation dose expected to the lung and bone in addition to the wholebody dose.

The discussion of the criticality accident (page 80) should be expanded in the final statement. The maximum dose to an individual at the site boundary should be estimated for release of iodines, noble gases and any direct radiation. The probability of a criticality and the estimated yield should indicate the dose commitment period considered. Also, the probability and effects of a tornado on the plant should be estimated.

While the probability of occurrence for each type of accident or natural disturbance is small, each could involve the release of radioactivity to the environment. The draft statement does not indicate the emergency response capability of the operator to minimize the environmental impact of different types of events. The final statement should include emergency plans of the operator as well as any involvement of state and local authorities.

Transportation

With regard to the transportation of the completed fuel assemblies, it is stated that they will be shipped to Idaho or to a reactor. If the fuel is shipped to Idaho, the accident rate would be 0.55 accidents plus those potential accidents which would eventually occur curing shipments from Idaho to the reactors. The alternative of storing the fuel at ORNL until shipment directly to the reactors was not addressed although it is apparent that this alternative would have a significantly smaller impact based on current projected locations of HTGR's. We believe this alternative should be considered in the final statement. 
NON-RADIOLOGICAL ASPECTS

Biological

Storm drainage is to be discharged directly to the Melton valley storm drainage system and the sanitary wastes are to be discharged to the Melton Valley area municipal treatment plant. Both the storm and sanitary wastes are to be monitored prior to discharge. Additional discussion is necessary to describe the nature of the agreement with the Melton Valley waste disposal authority, the quantities and nature of wastes involved, and the additional burden to be placed on the existing system. Also, with regard to the sanitary wastes, a discussion is needed on the pretreatment standards that will be met prior to discharge to the municipal treatment system. In addition, the final statement should further discuss the cumulative effects of the wastes from the proposed pilot facility in relation to the discharges from other Facilities at ORNI.

\section{Chemical}

The discharge of chemical emissions in the liquid waste releases, while containing only $1 / 25$ of the concentrations known to be lethal to aquatic organisms (page 85), could have long-term chronic effects that have not been considered. We recommend that the long-term effects of such emissions be examined in the final statement. 
Mr. Sheldon Meyers, Director office of Federal Activities U.S. Environmental Protection Agency Washington, D.C. 20460

Dear Mr. Meyers:

Thank you for your letter of Apri1 10, 1974 which provided comments on the Atomic Energy Commission's draft environmental statement for the HTGR Fuel Refabrication Pilot Plant, Oak Ridge National Laboratory (ORNL), Oak Ridge, Tennessee. The statement has been revised in response to your comments and comments from other agencies.

With respect to your suggestion that an assessment be made of the radioactive discharges from this plant and their relationship to the overall radiation levels in the area due to the combined releases from all site plants, the scope of this statement is limited to effluents from the subject fuel refabrication plant which contribute only a small percentage of the effluents. However, we are preparing an environmental assessment of the impact of al1 operations at the ORNL site including the radioactive effluents from other operating facilities. This assessment will be completed by the end of this year. The enclosed staff response covers other specific concerns which you raised.

We appreciate your continued interest in our programs. Copies of the final statement are enclosed for your information.

Sincere1y,

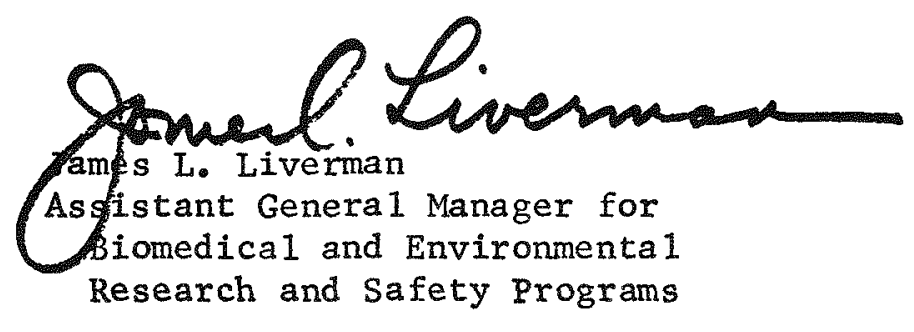

Enclosures:

1. Staff Response to EPA Comments

2. Fina1 Environmenta1 Statement - HTGR

Fue1 Refabrication Pilot Plant, ORNL, Oak Ridge, Tennessee (WASH-1533)

(3 copies) 


\section{ENCLOSURE 1}

STAFF RESPONSE TO COMMENTS FROM THE ENVIRONMENTAL PROTECTION AGENCY

\section{RADIOLOGICAL ASPECTS}

\section{Radiation Exposure}

The final statement has been revised to indicate that the dose shown in table 5 of WASH-1533 is the increase in dose to man due to additional inhalation of radionuclides resulting from the operation of the HTGR Fue 1 Refabrication Pilot Plant.

Revisions were also made to include an analysis of the consequences of the discharge and dispersal of long-lived radionuclides into the general environment.

\section{Air Cleaning}

Corrections have been made to indicate that the vessel hot off-gas system has two roughing filters and four HEPA filters in series before it ties into the cell exhaust system. The cell exhaust passes through one roughing filter and two HEPA filters in series.

\section{Decommissioning}

The final statement has been revised to include descriptions and quantities of wastes resulting from decommissioning the facility.

\section{Accidents}

The final statement has been revised to provide the radiation dose expected to the lung and bone in the event of a fire in the facility.

Revisions have been made to provide calculated doses expected from the release of halogens and noble gases and from direct radiation resulting from a criticality accident of $10^{19}$ fissions. Revisions have also been made to describe the probable effects of a tornado.

\section{Transportation}

The final statement has been revised to consider the alternative of storing the completed fuel elements at TURF rather than shipping them to Idaho. 
It should be noted that since the purpose of the HTGR Fue1 Refabrication Pilot Plant is only to develop and demonstrate the technology for remote fabrication of recycle fuel and not to fabricate large quantities of fuel for reactors, the projected locations of HTGRs have little bearing on the choice of storing the fuel at ORNL or shipping it to Idaho for storage.

\section{NONRADIOLOGICAL ASPECTS}

\section{Biologica 1}

The final statement has been revised to provide additional discussion on the treatment and discharge of storm drain and sanitary effluents and the pretreatment standards expected to be met prior to discharge.

\section{Chemica1}

The final statement has been modified to provide additional discussion on the expected long-term chronic effects of chemical emissions. 